
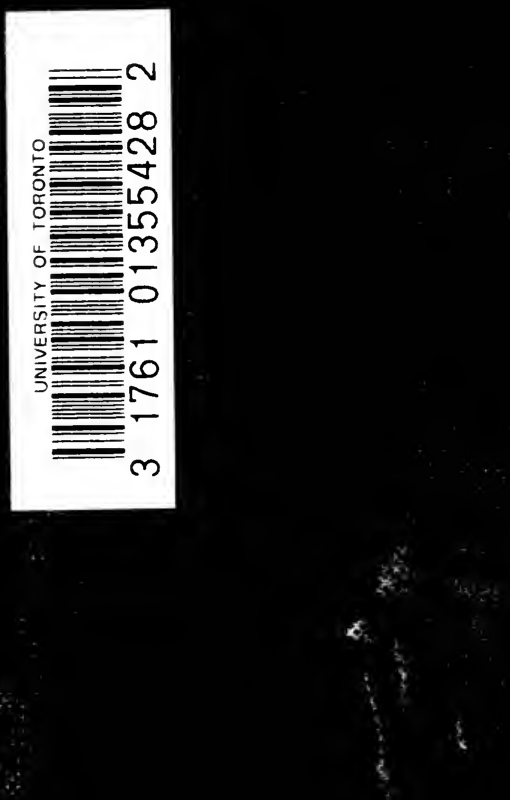

政 


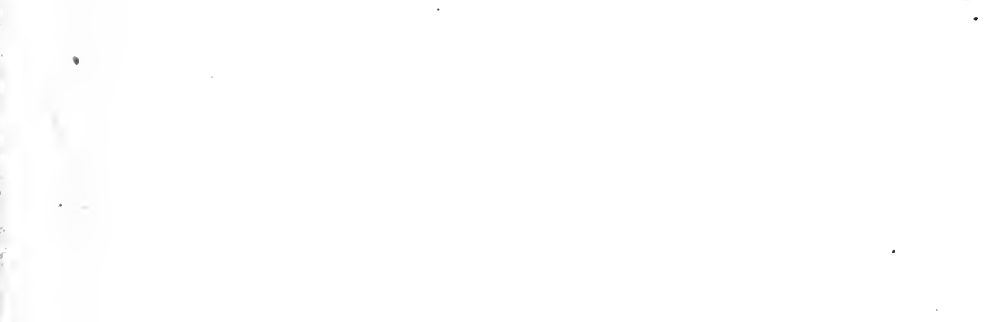




$$
\text { . }
$$


THE PHYSIOCRATS 
$\operatorname{sic}$ 


\section{THE PHYSIOCRATS}

SIX LECTURES ON THE FRENCH ÉCONOMISTES OF THE I8TH CENTURY

HENRY HIGGS
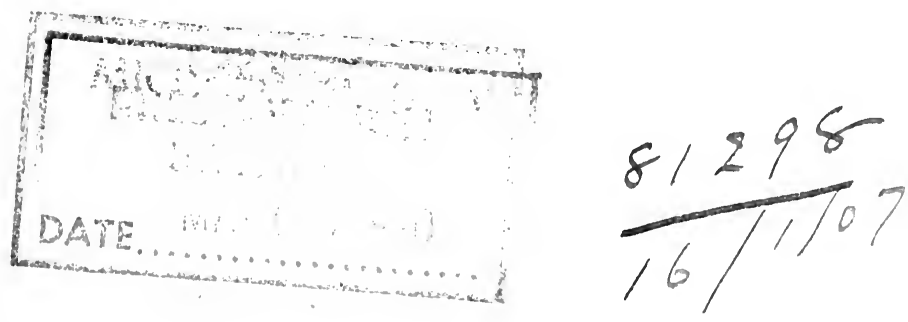

z⿺辶ñon

MACMILLAN AND CO., Limited

NEW YORK: THE MACMILLAN COMPANY

I 897 
To

唒erbert Zomerton Foxwell

MY

MASTER AND FRIEND 
7.

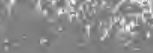




\section{PREFACE}

THIS little volume consists of lectures delivered before the London School of Economics in May and June of the present year. Impossible though it was found to give a truly adequate account of the Physiocrats in these six lectures, it has been thought that they may perhaps furnish a useful introduction to a subject upon which no book has yet been written in the English language, though its study has, during the last seven years, been deemed worthy to engage the active attention of many leading economists on the Continent of Europe. In Switzerland, Professor Oncken of Berne, and Professor Stern of Zurich ; in Germany, Professor Knies of Heidelberg, and Professor Hasbach of $\mathrm{Kiel}$; in France, M. Schelle ; in Austria, Dr. Bauer of Brünn, and Dr. Feilbogen of Vienna, are the most noteworthy recent contributors to our knowledge of this important chapter of economic theory. More hesitation would have been felt in publishing these lectures if M. de Lavergne's 
charming essays on the French economists of the eighteenth century had been translated into English. But the materials brought to light since r 870 by the researches of Professor Oncken, and the brilliant discoveries of Dr. Bauer, would have made it necessary to bring his work up to date, while it is evident that in choosing the subjects for his cabinet of cameos Lavergne was influenced rather by the fact that two of them (the Abbé de St. Pierre and the Marquis de Chastellux) were once, like himself, members of the French Academy, than by their intrinsic importance as economists, while they cannot, in any case, be ranked among the Physiocrats. The French writer's example has been followed in the effort to make the lectures interesting. To this end gleanings of research and minuter points of difference among authorities have been deliberately sacrificed where they appeared to be of secondary importance. For the same reason critical and doctrinal comment has been restricted within the narrowest limits. The reader who desires fuller information will turn to the monographs mentioned in the lectures, and, above all, it is hoped, to the original works of the Physiocrats themselves.

HAMPSTEAD, LoNDON, 1896. 


\section{CONTENTS}

RISE OF THE SCHOOL

France in the middle of the eighteenth century-Social and financial condition-Abuses under the ancien régimePolitical economy before the Physiocrats-BoisguillebertVauban-The Mercantilists-Cantillon's Essai sur la nature du commerce en genéral, I755-The Marquis of Mirabeau's L'Ami des Hommes, 1756 - Meeting of Mirabeau and Quesnay, July 1757-Origin of the School

\section{II}

\section{The SCHOOL AND ITS DOCTRINES}

Quesnay and his work-The articles "Fermiers" and "Grains" in the Encyclopedie, 1756-57-The Tableau Oeconomique, 1758-Production, distribution, and consumption of wealth -Social utility of Capital-Philosophy : moral, political, and economic-Economic policy-Produit net-FinanceThe impot unique-Free trade-Political constitutionPersonal influence of Quesnay-His death, I6th December 1774

\section{III}

The School AND ITS Doctrines (contd.)

The Marquis of Mirabeau-Life and writings-His leadership after Quesnay-Du Pont de Nemours-Gournay not a Physiocrat - Origin of maxims, Laissez-faire, Laissezpasser-Errors of Du Pont on this subject-Mercier de la Rivière-Baudeau-Le Trosne-St. Péravy-AbeilleRoubaud 


\section{Activities OF THE SCHOOL}

The Tuesdays - Journal de l'Agriculture-Ephemerides - The moulins économiques - The Caisse de Poissy-Foreign relations-Carl Friedrich of Baden-Gustavus of SwedenCatherine of Russia-Leopold of Tuscany-Joseph II.Charles III. of Spain-Stanislas of Poland-Ferdinand of Naples-The Dauphin-Turgot's writings and reformsMorellet-Condillac-Condorcet-Schlettwein-F. K. von Moser-Mauvillon-Schmalz-Krug-Iselin-Longo .

OPPONENTS OF THE SCHOOL

Forbonnais-Mably-Le Pessellier-Rivière-Guiraudet-de Casaux - Tifaut de la Noue-Voltaire-Galiani-Graslin -Necker-Linguet-J. J. von Moser-Pfeiffer-DohmVon Sonnenfels

\section{VI}

INFLUENCE OF THE SCHOOL

Their place in the history of theory-Criticisms by Adam Smith, Lauderdale, Gray (or "Purves"), M'Culloch, James Mill, Torrens-Influence on Malthus, Dugald Stewart, Paley, Spence, Proudhon, J. S. Mill, and Henry George-Relations to Say, Garnier, Bastiat, and modern French school

Authorities 
THE Physiocrats have been the subjects of so many and such divergent appreciations by historians, philosophers, economists, and students of political science, that hardly a single general proposition of importance has been advanced with regard to them by one writer which has not been contradicted by another. To de Tocqueville they were doctrinaire advocates of absolute equality. To Rousseau they were the supporters of an odious, if "legal," despotism. To Professor Cohn they are, in their main proposals, "thoroughly socialistic." To Louis Blanc they were tainted with a bourgeois individualism. To Linguet their mystic jargon was charlatanical nonsense, not to be understood even by themselves. To Voltaire it was so clear as to be made easily comprehensible (and ridiculous) to the meanest intelligence. To Taine, as to many others, they made powerfully for revolution. To Carlyle, who speaks ironically of "victorious analysis" and scornfully of "rose-pink sentimentalism," they seem 
to have been a mere literary ripple on the surface of the great flood. Rossi praised them for conceiving a vast synthesis of social organisation; certain writers, like Mably, have blamed them for a narrow materialism; while there are judges who pronounce them markedly deistic. To Proudhon their system of taxation was a rare Utopia; to others they lack an ideal of any kind. They were to de Loménic a bundle of contradictionsat once monarchical and democratic, half-socialist and highly conservative. To Adam Smith their "system, with all its imperfections, is perhaps the nearest approximation to the truth that has yet been published upon the subject of political economy, and is, upon that account, well worth the consideration of every man who wishes to examine with attention the principles of that very important science." To many compilers of little text-books, who know better than Adam Smith, they are merely people who lived in the dark ages before 1776 , and held some absurd opinions about land. To some they appear to have had a transitory success followed by complete and lasting reaction. To Léon Say their principles, after suffering reverses in the eighteenth century, have dominated the nineteenth. Of many serious writers these, anxious for precedent, have appealed to their authority in support of their own views; those, striving after originality, have been eager to prove that the point which they seek to emphasise was 
really missed by the Physiocrats; and the great majority of authors have been content to follow the well-worn phrases of one predecessor or another without direct reference to the writings of the old economists themselves. Probably no man alive has read the whole published works of, say, the Marquis of Mirabeau-to mention only a single member of the school. And happily no one is obliged to do so. When we have once mastered their doctrines we are dispensed from following the prolix repetitions and tedious amplifications which make up nine-tenths of their literary activity. Yet this mastery is essential to a due acquaintance with the history of economic theory. For the Physiocrats were the first scientific school of political economy.

The Mercantilists, it is true, come first in order of time, but they are not in any proper sense of the term "a school" at all. There is no personal link between the different writers who, for more than a century, support what is called "the mercantile system "-an indiscriminate phrase covering proposals so different that their authors can only be said to have had a common tendency and not a common doctrine any more than a common acquaintance. But in the Physiocrats we see an alliance of persons, a community of ideas, an acknowledged authority, and a combination in purpose, which banded them into a society apart. To this personal tie, Turgot, the great lover of individual liberty in thought and 
deed, took grave objection. "It is the sectarian spirit," he says, "which arouses against useful truths enemies and persecutions. When an isolated person modestly proposes what he believes to be the truth, he is listened to if he is right, and forgotten if he is wrong. But when even learned men have once formed themselves into a body, and say we, and think they can impose laws upon public opinion, then public opinion revolts against them, and with justice, for it ought to receive laws from truth alone and not from any authority. Every society soon sees its badge worn by the stupid, the crack-brained, and the ignorant, proud in joining themselves to it to give themselves airs. These people are guilty of stupidities and absurdities, and then their excited opponents fail not to impute folly to all their colleagues." Turgot refused to wear their intellectual badge, but, as we shall see, he shared many of their ideas.

The Physiocrats were not merely a school of cconomic thought; they were a school of political action. Kings and princes were among their pupils. The great French Revolution itself was influenced by their writings. And the force of their work is still not wholly spent. But before the origin and significance of their writings can be appreciated it is necessary briefly to sketch the circumstances of their time in relation to which their ideas must be considered. 
The economic and financial condition of France at the beginning of the eighteenth century was truly pitiable. In spite of her great natural resources, the variety of her favourable climates, the fertility of her well-watered soil, and the thrift, industry, and intelligence of her people, the efforts of able ministers like Mazarin and Colbert to increase her national wealth had been rendered nugatory by the senseless politics of the Great Monarch. Costly campaigns abroad, ruinous extravagance at home, left the kingdom at his death, in I7 I5, with a debt of 3460 million francs, of which over 3300 had been contracted since the death of Colbert in 1683 . His murderous wars, reducing the birth-rate, increasing the mortality, and "an act of religious intolerance, disavowed by religion " 1 - the expulsion of the Protestants - had reduced the population by four millions, or 20 per cent, since $1660 .^{2}$ Agricultural products had fallen off by one-third since he ascended the throne. Burdens increased while they were diminished who bore them. And competent judges computed that two-thirds of the taxes themselves were eater up by the cost of collection. ${ }^{3}$ The

.

1 Lavasseur, Reciherches historiques sur le système de Law, Paris, I854, p. I.

2 Lavergnè, Les économistes français du XVIIIe siècle, Paris, 1870 , p. 65.-Taine probably overstates the case when he estimates at six millions the deaths due to poverty and starvation alone between I690 and I 715 . L'Ancien Régime, vol. i. p. 430.

3 Quesnay, quoted by Lavergne, p. 79. 
contemptible creatures who succeeded Louis XIV., Philip, Duke of Orleans (the Regent), and Louis XV., squandered the national revenues in vice and frivolities with shameless prodigality. The system of Law ( I 7 I 8-1 720), which is generally held responsible for a large share of the subsequent financial trouble of France, had, it might be shown, little or no ill effect as a whole upon the royal treasury either immediately ${ }^{1}$ or in the long-run, for it taught useful lessons of the power as well as the dangers of credit, and proved by bitter experience to masses of men the folly of striving after fortune by gambling instead of by honest work. The Court maintained its outward ) brilliance, and the seigneurs who surrounded the king at Versailles vied with one another in splendour and extravagance, while their country houses were abandoned, and young labourers fled from the gloomy farms and the hated militia to the glitter of the cities and the security of domestic service with the great. An economic drain of wealth from the fields to the town thus intensified the contrast between luxury and misery, and a vicious financial system pressed with increasing weight upon the already crushed industries of the nation. The taille or direct tax (said to be etymologically related to our words tallage and tallies) was imposed only upon the

1 Those who vilify Law will find food for reflection in the fact that at the moment when he quitted France, ruined and disgraced, the Czar offered to place him at the head of the finances of Russia. Law declined the offer.-Lemontey, IIistoire de la Régence, I832, vol. i. p. 342. 
goods and persons of the common people, and not on the nobles or clergy, who by a relic of feudal fiction owed the king their personal service and not their money, so that subjection to taille was synonymous with and incidental to degradation from nobility. A man who could afford to buy a patent of nobility , obtained with it the privilege of exemption from taille; and the inequality with which the tax was levied, as between place and place, man and man, constituted an additional aggravation. $\mathbf{2}$. The gabelle, an indirect tax which had come eventually to stand simply for the tax upon salt, was collected at the rate of 62 francs a quintal in some provinces, at 33 francs 12 sous in others, at 2 I francs 12 sous in others, while certain districts had either redeemed it or been exempted from its operation. Except in these favoured districts every person over eight years of age was compelled to pay on at least a certain quantity of salt (sel de devoir); and the tax was collected with revolting harshness at a cost of about 50 per cent. The indirect taxes were leased out to a body of financiers, the farmers-general, who paid a fixed sum in advance year by year and purchased thereby the taxes they collected. Armed with stringent powers they paid domiciliary visits, seized goods suspected to be smuggled, and in their efforts to capture smugglers (whose fate was the galleys or the gibbet) they frequently. provoked strife and bloodshed. "Those who consider the 
blood of the people as nothing," says Adam Smith, "in comparison with the revenue of the prince, may, perhaps, approve of this method of levying taxes." 1 - The corvée, an obligation upon the peasant to supply the state with labour or services without payment,e.g. to work so many days in the year on repairing the roads, - was extended to the whole country in I 737, and was estimated in I 758 to yield $1,200,000$ livres' worth of forced labour, though its cost to the peasants greatly exceeded this sum, and was stated by Necker to amount to 624,000 livres a year in Berry alone. It included also the billeting and the transport of soldiers. The regular army was, it is true, recruited by enlistment and not by conscription; but each district was compelled to provide its quota for the militia; and this service was so distasteful that the men whose names were drawn often fled to the woods or the mountains, and were pursued by their neighbours' in arms who had no relish for serving in their stead. Voluntary substitutes were not accepted lest recruiting should suffer. 4Apart from these and other national vexations there were the tithes of the clergy and numerous troublesome local dues. Minute regulations fettered industry and commerce; tolls had been lightened and simplified by Colbert in $1664,{ }^{2}$ but Forbonnais still mentions twenty-eight on the Loire alone. Until I 754 corn

1 Wealth of Nations, bk. v. ch. ii.

2 See P. Clément's Colbert, Lettres et Instructions, ii. 2, 787-796. 
could not be freely "exported" even from one part of France to another, much less to foreign countries. And at the peasant's own door were the innumerable fees, often for absurdly trifling amounts, but none the less irritating, due to his feudal lord. Financial deficit was chronic. The capital of the nation, its industrial life-blood, ebbed away and left it weaker and weaker. Even the seed-corn was often lacking. In the first half of the century large territories lay waste, and over great tracts of country the poor were reduced to live on grass and water, like the beasts of the field. When the king asked the Bishop of Chartres how his flock fared he was answered that they ate grass like sheep and starved like flies. The Bishop of Clermont-Ferrand described his peoplewithout beds or furniture, and lacking half their time the barley-bread or oaten cakes which constituted their sole food-as infinitely less fortunate than the negro slaves of the colonies, who had at least food and raiment. The government intendant of Bourges reported that whole families passed two days without food, and' that in several parishes the starving lay abed most of the day to diminish their suffering. His colleague of Orleans refers to poor widows burning their wooden beds and their fruit-trees for lack of fuel. Beggars abounded. Bread riots were frequent, and so desperate that they were only quelled by lead and cold steel. Young men and maidens refused to marry, asking why they should add to 
the misery around them. And all the while taxes were ruthlessly wrung from the poorest families. The collectors forced doors, seized furniture and clothing, and even the last measure of meal, and sold the very materials of the building, often for ridiculously small sums, barely sufficient to pay the expenses of distraint. The duties levied upon land were so onerous that some proprietors preferred to abandon their property, and more would have done so if the law had not confiscated the whole local property of an owner who left his land derelict. "The people," says Taine, "is like a man walking in a pond with water up to his chin; the least dip in the ground, the least ripple, and he loses footing, goes under, and suffocates. In vain ancient charity and new humanity strive to succour him; the water is too high. Its level must abate, and the pond find some great outlet. Till then the miserable man can breathe only at intervals, and at every moment will run the risk of drowning." ${ }^{1}$ Here and there, no doubt, the people hoarded a little money and enjoyed some surreptitious comfort; but they either bought parcels of land, which brought home to increasing numbers the tyranny of taxation, or they hid their money in secret hoards; for a man was assessed according to his apparent wealth, and there was no

1 Taine, L'Ancien Régime, vol. i. pp. 429-44I. He works out the average taxation of a small peasant proprietor (taille, etc., tithes, and feudal dues) at nearly 82 per cent of his total net produce, p. 543 . 
inducement to stock a farm well or work it to greater advantage when the rapacity of the taxgatherer might confiscate more than the whole of the increased profit. Payment of taxes was wilfully delayed, law costs were deliberately incurred, and sheriff's officers were housed and fed for days together lest a readier payment should provoke suspicion of greater wealth, and lead to increased assessments the following year. The nobles, indeed, stood between the people and the crown, but it was only, in the bitter words of Chamfort, as the hounds are between the hunter and the hare; and the fierceness of popular indignation, which was directed first against the agents of the royal treasury, vented itself upon the privileged classes before it spread to the throne in that "general upset" which the elder Mirabeau clearly foresaw, and his son was to be instrumental in bringing to completion.

Such in barest outline were the economic woes of the ancien régime. So deplorable a condition of things could not fail to evoke the criticism and suggestion of thinking men. Passing by La Bruyère and Fénélon, we come, at the end of the seventeenth century, to a courageous, outspoken, and well-informed writer in Boisguillebert ( I 646-I 7 I 4), ${ }^{1}$ a state official of Normandy, who mercilessly exposed the blunders of administration, the misery of the people, and the connection of one with the other. He urged

1 Detail de la France, 1697; Factun de la France, 1707. 
upon successive ministers plans of reform, the consolidation and reduction of taxes, and, convinced that agriculture, the all-important business of the country, was being stifled, he pressed for the abolition of fetters upon internal and export trade, ${ }^{1}$ until he was disgraced and exiled to Auvergne as a warning against meddling importunity. In I 707 the great soldier, Marshal Vauban, in his seventy-fourth year, printed anonymously, for private circulation, his Dixme Royalc or proposal to substitute for a host of other taxes a general tithe upon all classes of men and all kinds of revenue, and died the same year, chagrined at the king's severe disfavour, and the suppression of his book as a social danger. ${ }^{2}$ The army of financiers and functionaries found their occupations menaced by this hardy plan for the simplification of taxation. The anger of the privileged classes was easily roused by proposals to tax them equally with others. The amour propre of the king himself could not fail to be wounded by the rude simplicity with which Vauban proved him to be, as St. Simon wrote in the security of his

1 He did not, however, desire free imports except when famine was to be feared.

2 See the researches on this subject of A. M. de Boislisle, De la proscription de la dîme royale, Paris, 1875 . The official papers there printed prove how much Vauban took to heart the arrêts against his book, and how rigorously they were carried out ; while they disprove the allegation that the Abbé de Beaumont, as alleged by Voltaire and others, was its real author. The arrêt which proscribed the Dixme Royale was followed the same day, 14th March 1707, by another suppressing Boisguillebert's Factum de la France as seditious. 
closet, not the greatest monarch in Europe, but "a king of tatterdemalions." In my forty years' wanderings, says Vauban in effect, I have carefully noted the state of the people. Boisguillebert ${ }^{1}$ is perfectly right. Taxation has reached a pitch of absurdity. Naked, starving mendicants swarm the streets and roads. "Of every ten men one is a beggar, five are too poor to give him alms, three more are ill at ease, embarrassed by debts and law-suits, and the tenth does not represent 100,000 families. I believe not I 0,000 great or little are really well-to-do, and these include rich merchants, officials, and the favoured of the king. Take them away and hardly any remain." He stigmatised luxury, privilege, public debts, and the farming of taxes; extolled labour, agriculture, and equality before the law ; and reiterated in capital letters the warning that kings have a real and most essential interest in not overburdening their people to the point of depriving them of the necessaries of life. Half a century was to pass before Vauban's ideas reappeared, in a modified form, with the Physiocrats, and then their spokesman was clapped into prison for using similar language. Such was the encouragement afforded to these early writers on taxation. After Vauban they kept long silence, and the intellect of the nation seemed to lie fallow. "The government," says Buckle," "had broken the

1 Vauban had made his personal acquaintance.

2 Hist. of Civilisation in England, vol. ii. p. 29I, ed. I868. 
spirit of the country." Writings on paper money raged round the system of Law; and Melon, a former secretary of Law, published in I 734 his overrated Essai politique sur le commerce. The Abbé Alary had indeed founded a little club, the Club de l'Entresol, in 1724 , which counted Bolingbroke, D'Argenson, and the Abbé de Saint-Pierre among its members, and met in the Abbé Alary's rooms, ${ }^{1}$ in the Place Vendôme at Paris, to discuss political economy. But the club was closed in $173 \mathrm{I}$, because the Cardinal de Fleury, then minister, disliked its debating Government affairs. Saint-Pierre, who had been expelled from the Academy for denying to Louis XIV. the title of Grand, turned his prolific pen from one project to another; from spelling-reform to utilising horse-chestnuts, from the advantage of a census to the disadvantage of debasing the coinage, and dreamed a dream of Universal Peace. But his writings, though some of them are not without economic importance, need not detain us. And D'Argenson's ${ }^{2}$ economic reflections appeared only in I764. During the whole of the first half of the eighteenth century the Government

1 In the house of President Henault. A full account of the club was written by D'Argenson, Mémoires, I825, pp. 247-269. The chatterbox Abbé de Pomponne was the cause of its suppression. Lavergne's history of its foundation is erroneous.

2 Sainte-Beuve devoted two of his Causeries du Lundi to D'Argenson (3rd and Ioth Nov. 1853), vol. xii. p. 93, edition of 1857 . He tells us that the Considirations of 1764 were a very defective edition of the original manuscript, and that the edition of 1784 , "which passes for better," is still imperfect and inaccurate. The title designed by D'Argenson himself was Jusques oì la démocratie penit être admise dans le gouvernement. 
underwent little public criticism. It was the calm before a storm. After the Peace of Aix-la-Chapelle in 1748 began a veritable renaissance in every department of thought,- -in religion, in politics, in philosophy, and in science,-largely under the impulse of English writers, and especially of Locke. The old crystallised forms of thought and action were broken up by the solvent of free criticism and fearless inquiry. Montesquicu's Esprit des Lois appeared in 1748. The Encyclopédie of Diderot and D'Alembert was started in I75I. Voltaire and Rousseau were sharpening their pens, and had even begun to write. Gournay, appointed intendant of commerce in $175 \mathrm{I}$, devoted his attention to the English economists, translated Child and Culpeper, and directed into the same channel the mental activity of Turgot, whom he persuaded to translate a volume of Tucker. The original and suggestive essays of Hume appeared in a French translation (1 7 56). The efforts of Du Pin, ${ }^{1}$ Gournay, Trudaine, Fourqueux, and Machault had assisted in wringing from the Government an edict in 1754 permitting free trade in corn between one part of France and another; and Herbert had argued (Essai sur la police des grains, I755) in favour of free export.

1 A farmer-general, and grandfather of Georges Sand. His tract on the corn trade, separately printed under the title Mimoire sur les Bleds, I 748, is the first plea for free trade in corn by a French writer. It formed a chapter of his Oeconomiques, Carlsruhe, 1745, 3 vols., rigidly suppressed, and now extant in only three copies. 
But the work which heralded in the era of active and original thought in French economics was Cantillon's Essai sur la nature du commerce en général, I 755 , a little volume of 430 pages duodecimo, immeasurably superior to anything which had preceded it, and profoundly important by the influence which it exercised over the minds of leading writers. ${ }^{1}$ Cantillon, who died in I 734, was an English banker of Irish extraction. He had houses in all the principal countries of Europe, made a great fortune out of sagacious operations at Paris cluring the "system" of Law, and studied with great penetration the general principles which regulate the production, distribution, and consumption of wealth. His original English writings are unfortunately lost; but his Essay was handed about in manuscript, and a translation of part of the Essay which he made for a French friend is all that we have remaining of him. The Mercantilists seem always to have propounded to themselves the problem, How can Government make this nation prosperous? Nationalism, state-regulation, and particularism are the essence of their policy. But a

1 See the fascinating essay of Jevons on Cantillon in Contemporary Review, January I88 I, "The Nationality of Political Economy." The present writer has added some further information upon Cantillon's life and work in the Economic Journal, vol. i. No. 2, June I891. Kautz points out that some of the ideas of the Physiocrats are to be found in Asgill, Several Assertions Proved in Order to Create Another Species of Money than Gold and Silver, 1696, and in Vanderlint, Money Answers all Things, 1734. It would be easy to multiply such references, but there is no evidence that the Physiocrats were acquainted with them. 
man of much travel is less prone to be trammelled by narrow views of local circumstance, as had already been shown by Dudley North in his tract of I69I, the Discourse of Trade, and especially by Nicholas Barbon in his book of the same title a year before. ${ }^{1}$ In Cantillon and his successors we find broader and more philosophical views of the fundamental principles which govern the Science of Wealth at all times and in all places, though time and place are not without their modifying effect. The Hu: is en général which figure in his title are significant of much. They mark a change from works like Mun's England's Treasure by Forraign Trade (published I 664), Malynes's Canker of England's Commonwealth ( I60 I), Fortrey's England's Interest and Improvement (1663), Britannia Languens (I680), Yarranton's England's Improvement by Sea and Land (I677, I68 I), and others, to the cosmopolitan spirit which Adam Smith was to show in his Inquiry into the Nature and Causes of the Wealth of Nations (1 776$)$ of nations in general and not of England in particular. Cantillon sets himself to answer the questions, What is wealth? How does it originate? What are the causes which regulate its distribution among the different classes of society, and determine its circulation not only within the country but between one

1 On Barbon see the articles of Dr. Stephan Bauer, by whom his importance was first fully recognised, in Palgrave's Dict. of Pol. Econ. S.v., and in Conrad's Jahrbücher fur Nationalökonomie und Statistik, xxi. Bd. N.F. pp. 561·590 (1890). 
country and another? "Land," he begins (and this is the keynote of physiocracy), "is the source or material from which Wealth is extracted"; but he continues, "human labour is the form which produces it; and Wealth in itself is no other than the sustenance, the conveniences, and the comforts of life." He sketches the growth of human societies, beginning with the nomadic stage, and concludes that in all forms of society the ownership of land necessarily belongs to a small number; that in modern societies, after satisfying the claims of farmers and labourers, the surplus product is at the disposition of the landowners, and that their mode of consuming this surplus will determine the nature of national production. After dwelling upon the formation of villages, hamlets, towns, and cities, he passes to a consideration of labour, shows why the work of an agricultural labourer cannot command such high wages as that of an artisan, and distinguishes between the causes which regulate the difference of wages in different industries. The supply of labour of all kinds is determined by the demand for it; and, generally, the normal price of all services and commodities is regulated by the cost of Production. Without. pursuing his analysis further, or dwelling upon his masterly account of foreign exchanges, it will be seen that this manner of attacking the problem at once raises economic discussion to the highest plane. ${ }^{1}$

1 Cf. Higgs, "Cantillon's Place in Economics," in Quartcrly Journal 
It has been mentioned that Cantillon's manuscript had been handed about before its publication. Postlethwayt plagiarised large portions of it verbatim in his Universal Dictionary of Trade and Commerce as early as I75I. ${ }^{1}$ But the French translation, subsequently published, had been for many years in the hands of the Marquis of Mirabeau, father of the great orator and tribune of the French Revolution. Mirabeau seems at one time to have meditated publishing this fragment as his own work; but he eventually set himself to write a commentary upon it, and after the Essai itself had been reclaimed from him and given to the world in 1755 he expanded and published his commentary under the title of L'Ami des Hommes, Avignon, I756, which took the public by storm. The anonymous author was soon revealed. He became the lion of the hour. The people flocked to see him when he showed himself in public. Tradesmen set up the sign-board of L'Ami des Hommes, and Mirabeau himself was so designated to the day of his death. His book ran, it is said, through forty editions, and was widely translated. Its peculiarities of style accounted for part of its success. The Marquis's first work was a plea for decentralisation of local

of Economics (Harvard, U.S.A.), July I 892. · An analysis of Cantillon's essay is given in Espinas, Histoire des doctrines économiques, Paris, $189 \mathrm{I}$.

1 A fact first noticed by Mr. Edwin Cannan. See Econonic Journal, March I896, p. 165. 
government published in I750, the Mémoire concernant l'utilité des états provinciaux. The country was divided into two groups-pays d'ctat and pays d'clection, in the first of which (consisting mainly of the frontier provinces) the inhabitants themselves decided how to raise the money demanded from them by royal precept, in the second, the officials of the Government (the intendants) allotted its share of burden to each parish. Mirabeau pleaded for a general extension of the system of the pays d'etat. His Mémoire had been attributed by D'Argenson, no mean judge, to Montesquieu. The Ami des Hommes now reminded readers of the naïve prattle of Montaigne. Here it glowed with the fire of eloquence, there it glittered with wit and humour, elsewhere it exhibited shrewd observation, sober judgment, and able, though often inconsecutive, discussion. Its success owed something to its style, where quaint archaisms jostled with words freshminted by the author, and provoked Quesnay to write Oic diable avez-vous pris ce style marotique? Je ne connais pas Marot, was the answer, mais apparemment j'ai bu de la même eau que lui. Victor Hugo finds in him the style of Molière and SaintSimon, the beau style-grand-seigneur du temps de Louis XIV. The sub-title of the book was Traité de la Population, and its central purpose was to show that a large population was desirable as conducive to the wealth of the country. It was a time of Mareantikistac 
peace, and the population was already recovering from the set-back it had experienced during half a century. But it was seen that for a long time there had been, side by side with a diminution of population, a reduction in national wealth ; and in Mirabeau's view the problem of the statesman was to remove the economic causes which kept down the numbers of the people. "Men multiply," he says, borrowing from Cantillon, "like rats in a barn, if they have the means of subsistence." "The means of subsistence are the measure of population." The production of food should therefore be assisted. The burdens of agriculture should be alleviated. The small cultivator was to be encouraged and held in honour; the idle consumer viewed with reprobation. .Luxury he defined as the abuse of wealth. An unequal distribution of wealth is prejudicial to production, for the very rich are "like pikes in a pond" who devour their smaller neighbours. Great landowners should live upon their estates and stimulate their development, - not lead an absentee life of pleasure in the metropolis. Interest should be reduced, public debts extinguished, and a ministry of agriculture created to bring to agriculture the succom of applied science, to facilitate the develop. canals, communications, drainage, and so forth. The state is a tree, agriculture its roots, ${ }^{1}$

${ }^{1}$ Cf. Leibnitz in Dutens, G. G. Leibnitii Opera omnia, Geneva, I768, vol. v. p. 577.-Quesnay, art. "Grains" in Encyclopédie, I 757. 
population its trunk, arts and commerce its leaves. From the roots come the vivifying sap drawn, up by multitudinous fibres from the soil. The leaves, the most brilliant part of the tree, are the least enduring. A storm may destroy them. But the sap will soon renew them if the roots maintain their vigour. If, however, some unfriendly insect attack the roots, then in vain do we wait for the sun and the dew to reanimate the withered trunk. To the roots must the remedy go, to let them expand and recover. If not, the tree will perish.

Such was the burden of the book which fell into the hands of Quesnay, a doctor at the court, in attendance on Madame de Pompadour, the mistress of the king. Quesnay, the son of an advocate, ${ }^{1}$ had early distinguished himself as a surgeon and physician, and had come to court as the Abbé de Saint-Pierre had done before, and perhaps from the same motive. This is how the Abbe had expressed himself in a letter to a friend: "I have taken a little opera-box to get a better view of the principal actors on the stage of the world. I see our Government at its - headquarters, and already I perceive that it would

This became a favourite figure with the Physiocrats, see e.g. Le Trosne, De Tordre social, 1777 .

1 According to Grand Jean de Fouchy, Eloge de Quesnay, 1774, and the Comte d'Albon's Eloge, I 775. Other accounts say his father was a peasant. The truth seems to be that his father left his wife and child at home on a small farm, and that, in cffect, Quesnay's early childhood was that of a peasant's son. IIe was taught to read by a friendly gardener at the age of twelve. 
be easy to make it much more honourable to the king, much more convenient to his ministers, and much more useful to the people." 1

If these, too, were Quesnay's motives, he purchased his advantages dearly; for, as will be found, his official position fettered his freedom of action very considerably. He was now over sixty-three years of age, had written nothing on economic subjects except two recent articles, "Fermiers" ( 756 ) and "Grains" (1757), in the Encyclopédie of Diderot, and the courtiers by whom he was surrounded seem to have regarded him as a harmless eccentric with a mania for agricultural science. But there was much in Mirabeau's book of which he approved. "The child," he wrote on the margin, "has been nursed on bad milk: the strength of his constitution often sets him right in the 1 , but he has no knowledge of principles." He expressed a desire to meet the author, and they had an interview, of which Mirabeau, many years later, wrote a graphic and perhaps somewhat fanciful account to Rousseau. Quesnay, he says, showed him that Cantillon had set the plough before the oxen,- that population was not a means to national wealth, but vice versâ. Quesnay sketched his own ideas to the Ami des Hommes, who confesses that, much as he had written, his mind was still swimming in an ocean of uncertainties. He thought the doctor mad, and quitted him. But he came

1 Lavergne, p. 5. 
back the same night, renewed the discussion, and was converted into a life-long disciple and friend. Each found in the other the qualities lacking in himself. Quesnay, aged, sententious, oracular, personally retiring, timorous in action, but a hard thinker, who had carved out for himself a consistent theory, -the marquis, young (for all his forty-two years), garrulous, diffuse, egotistic, daring, and imaginative, but unsystematic and incapable of sustained connected thought. As an example of his boldness take the following extract from L'Ami des Hommes, in which the preface declares that he personifies la voix de l'humanité qui réclame ses droits. Sire, he says to the king, regard that class of your subjects which is "the most useful of all, those who see beneath them nothing but their nurse and yours -mother-earth; who stoop unceasingly beneath the weight of the most toilsome labours; who bless you every day, and ask nothing from you but peace and protection. It is with their sweat and (you know it not!) their very blood that you gratify that heap of useless people who are ever telling you that the greatness of a prince consists in the value, and above all, the number of favours he divides among his courtiers, nobility, and companions. I have seen a tax-gathering bailiff cut off the wrist of a poor woman who clung to her saucepan, the last utensil of her household, which she was defending from distraint. What would you have said, great Prince?" 
etc. etc. This fiery spirit was never quite kept in check by Quesnay's influence, but the energy which lay behind it soon raised up a band of followers for the solitary thinker of Versailles. The school of the Physiocrats dates from this interview in July I 757 . 


\section{II}

FrançoIs QUESNaY, the founder of the school of the Économistes (or, as they came to be called in later years, the Physiocrates), was born at Méré near Versailles on the 4th of June I694, the same year as Voltaire, and died at Versailles on the I6th December I774, the same year as Louis XV. His first published work was Observations sur les effets de la saignée, I 730, in which he successfully opposed the theories of bleeding of Silva, the leading contemporary medical authority. The reputation of this work led to his selection as Secretary of the Academy of Surgery at Paris, founded I73I. In I 736 he published an Essay physique sur l'économie animale, in I 749 a Traite de la suppuration, and a Traité de la gangrène, and in 1753 a Traité des fières continues. Meanwhile defective eyesight had led him to abandon surgery for medicine. In 1749 he had settled at Versailles as physician to Madame de Pompadour. In 1752 he successfully attended the Dauphin for smallpox, and was rewarded by being appointed physician to the king, and given a patent 
of nobility. ${ }^{1} \quad$ In 1756 he published an anonymous, metaphysical article on "Évidence" ${ }^{2}$ in the Encyclopédie, in which appeared the same year his article "Fermiers," and the following year "Grains," both over the signature of his son, Quesnay le fils; for the doctor's official position restrained him, as he thought, from publicly writing upon matters of government and administration, and he invariably, throughout his life, published his economical views anonymously or pseudonymously,--sometimes under the name of one of his disciples. The article "Fermiers" begins by balancing with minute detail and intimate knowledge the direct and indirect advantages of using horses or oxen in cultivation, and decides in favour of the former,--the grande culture, as against the petite culture. ${ }^{3}$ Most farmers, Quesnay admits, were too poor to employ horses. The result was a great national loss of wealth. The disastrous poverty of agriculture was mainly due to three causes: (I) the desertion of the children of the peasantry, driven by penury, taille,

1 See Note A, Appendix. The common assertion that this was a recognition of his economic studies is clearly unfounded. These had not yet seen the light.

2 This article was largely due to his study of Malebranche, Recherche de la Vérité, 1675; Traité de Morale, 1684. It is to be noted that the ordre de la nature of this article differs entirely from the beneficent ordre naturel of Quesnay's later economic writings, which was, in Professor Hasbach's opinion, borrowed from Cumberland, Disquisitio de legibus naturae philosophica, London, 1672, 4to, translated by Barbeyrac, Traite des loix naturelles; 1744.

3 Under the later influence of Turgot these terms came to mean, in a more general sense, high farming (a liberal application of capital) as against low farming. 
and milice ${ }^{1}$ to immigrate into the large towns, whither they brought some of their parents' little capital ; (2) the arbitrary taxation which deprived agricultural investors of security in their property; (3) the restrictions which embarrassed the corn trade. It might, he says, be worth while to -exempt farmers' sons from the militia, as some of them chose a town life to evade this service. He satirises the view that indigence is a necessary spur to rural industry: hope is a better stimulus than despair, and activity is proportioned to success. He examines the agricultural statistics of the country, of acreage, arable and pasture, live stock, population, production and consumption of corn, the range of prices; expenses of production, and profits. Agriculture was the fundamental industry of the country; liberty and security were its chief requisites. Free trade in corn, permission, and even (as in England) encouragement to export, would greatly diminish fluctuations in annual prices, and conduce to the prosperity of farmers, which would in turn beget further prosperity, and result in higher and more lucrative farming, increased national and individual wealth, a larger and healthier population, and a more flourishing treasury. But, above all, the arbitrary taille was to be given up. Quesnay did not see, he says, how to impose taxation on any just and simple principle;

1 See p. 8, supra. A little later he adds the corvese to the list of abuses needing abolition. 
his impôt unique had not yet presented itself to him as the perfect solution of this problem. "La répartition proportionnelle n'est guère possible. . . . Il n'est guère possible d'imaginer aucun plan général pour établir une répartition proportionnelle des impositions." Following, probably, the Abbé de SaintPierre's plan of a taille tarifée, he suggested that a personal declaration, somewhat resembling our income tax returns, might be the best basis for assessment. But at any rate the taxes should be, as Adam Smith urged some years later, certain, or, in the language of Bentham, cognoscible.

The only writers mentioned in this article are Locke and an agronomic authority, Dupré de Saint Maur. In the next article, "Grains," we have a much more significant and important exposition of Quesnay's views. For a long time the policy of the Government had been to stimulate manufactures (and especially those of luxuries like silk stuffs), to the detriment of agriculture. The people had been forbidden to plant vines, and encouraged to plant mulberry-trees. The true national economic policy was to turn to account the great productive powers of the soil of France, and buy luxuries from abroad - exactly the reverse of what was being attempted. The country would leap into prosperity by good harvests of corn and a free corn trade, at home and abroad. The actual production of corn in the country he estimated as worth about 595,000,000 of livres 
a year. If properly cultivated, with horses everywhere, the harvests would amount to I, 8 I 5,000,000, or more than three times as much; while the surplus, after paying all the costs of production, would be $885,000,000$ compared with I 78,000,000, or nearly five times the amount. ${ }^{1}$ The details are as follows :-

\begin{tabular}{|c|c|c|c|}
\hline Landlords & . & $\begin{array}{c}\text { Actual. } \\
76,500,000\end{array}$ & $\begin{array}{c}\text { Possible. } \\
400,000,000\end{array}$ \\
\hline Taille & . & $27,000,000$ & $165,000,000$ \\
\hline Farmers & - & $27,500,000$ & $165,000,000$ \\
\hline Tithe & . & $50,000,000$ & I $55,000,000$ \\
\hline Cultivation & & 4 I $5,000,000$ & $930,000,000$ \\
\hline
\end{tabular}

Agriculture and commerce are regarded as the two resources of wealth in France; but this distinction is, he says, a mere abstraction, for commerce and industry (which is much more, considerable than commerce) are but branches of agriculture,-the primary and indispensable source of the other two. The policy of Sully and the "fundamental truths" expressed by Cantillon are praised, the hindrances to viticulture and the wine trade deplored. Large farms, raised to their highest value by well-to-do farmers, are the true basis of prosperity and of a large population. By a rich farmer he means not "a workman who himself tills the soil, but an entre-

1 He makes some trifling allowances for taxation, but his arithmetic is often inexact. 
preneur $^{1}$ who governs and manages his enterprise by his intelligence and his wealth." "Those who regard the advantages of a large population only as a means of recruiting large armies judge but ill of the strength of a state. The military merely consider men as potential soldiers; but the statesman regrets men destined for war as the landlord regrets land laid out in a ditch to preserve his field. Great armies drain a state, a large population and much wealth make it redoubtable. ... Without human labour land has no value. Men, land, and cattle are the primitive wealth of a great state." The taille, he now suggests, should be based upon the farmer's rent, so as to spare taxation of his means of production, and to enable him to take the taille into account when considering what rent to offer for his farm. This ideal is not easily attained in the present state of affairs, and for that reason he had proposed a different system in his article "Fermiers"; but his new idea might be applied forthwith to farmers on lease, and, though not without difficulty, to metayers. He would not speak of the petty policy attributed to the Government ${ }^{2}$ of regarding arbitrary taxation

1 This is a noteworthy early use of an economic term whose origin is sometimes attributed to J. B. Say.

$2 \mathrm{He}$ refers here to Remarques sur les avantages et les désavantages de la France et de la Grande Bretagne par rapport au Commerce et aux autres sources de la Puissance des Eitats. Traduit de l'Anglois du Chevalier John Nickolls, Leyden and Paris, 1754. This work, which owes something to Tucker's Brief Essay on Trade, 1750, was constantly present to Quesnay's mind in writing this article and was quoted in the course of it. The real author of the pretended transla- 
as an assured method of keeping its subjects in submission. Conduct so absurd was not to be imputed to great ministers, who all knew how objectionable and ridiculous it would be. The taillables were men of very modest fortune, needing to be encouraged rather than humiliated. The author of the Remarques, contrasting the enlightened policy and the wealth of England with the unwise policy and the poverty of France, had concluded that England had nothing to fear from her neighbour. But let us adopt free trade, says Quesnay, and we shall be as rich as they. We might, indeed, seem to be in danger from the fertile soils of America; but their competition is not much to be dreaded, for their corn is not of such good quality; it deteriorates in the sea-voyage; and they will soon need all their corn themselves. ${ }^{1}$ Our corn makes better bread, and keeps in better preservation.

Arrived at this point he proceeds to compare the advantages of a foreign corn trade with that of a trade in manufacture, and lays down fourteen maxims of economic government. Of these maxims, each followed by a short explanation, we shall hear

tion was Plumart D'Angeul; and the book was done into English and published at London in $\mathbf{I} 754$ after its appearance at Paris. Daire, by an extraordinary blunder, attributes it to Thomas Mun, and gives the date as 1700 . Physiocrates, vol. i. pp. 264, 285.

1 Cf. a distinguished modern writer in $\mathbf{1 8 8 2}$. "It seems certain that in twenty-five years' time, and probably before that date, the limitation of area in the United States will be felt."-Giffen in Statistical Joumal, vol. xlv. p. 543 . 
again. Like other parts of this article they are steps towards his crowning work, the Tableau Oeconomique. (I) Labour expended in industry (les travaux d'industrie), as opposed to agriculture, does not multiply wealth, though (2) it contributes to population and the increase of wealth, unless (3) it occupies men to the prejudice of agriculture, in which case it has the contrary effect. (4) The wealth of the agriculturist begets agricultural wealth. (5) Industrial labour tends to increase the revenue from the land, and this again supports industry. (6) A nation having a large trade in its raw products can always keep up a relatively large trade in manufactures; but ( 7 ) if it have little of the first and is reduced to the second for subsistence, it is in a dangerous and insecure condition. (8) A large internal trade in manufactured articles can only be maintained by the revenue from the land. (9) A nation with a large territory which depreciates its raw products to favour manufactures, destroys itself in all directions. (I0) The advantages of external trade do not consist in the increase of money. (I I) The balance of trade does not indicate the advantage of trade or the state of wealth of each nation, which is (12) to be judged by both internal and external trade and especially by the first. (I3) A nation which extracts from its soil, its men, and its navigation the best possible result needs not grudge the trade of its neighbours, and (I 4) in reciprocal commerce 
nations which sell the most useful or necessary commodities have the advantage over those which sell luxuries. Finally, he sums up the measures which Government should take to render the country prosperous: freedom in the production and circulation of goods; the abolition or diminution of tolls on transport; the extinction of local or personal privileges in dues of the same character; the repair of roads and of river communication; the suppression of the arbitrary discretion of private persons in subordinate administrations, so far as the national revenue was concerned. With these reforms progress would be rapid. Under Henri IV. the kingdom, worn out and burdened with debt, soon became a land of wealth and abundance. To persist in the present courses would devastate the country. A hundred years ago there was a population of $24,000,000$. In 1700 , after forty years of almost continuous war and the revocation of the Edict of Nantes, there were still 19,500,000. To-day there are but 16,000,000, and many of these in extreme misery. Prices must not be ton low, for abundance and inability to sell are not wealth; dearness and penury are misery; ahminanre and , frir price, normal and continued, are opulence. The export of surplus corn would conduce to this fair price. Something must be done to remedy the "enormous degradation of agriculture and of the population." 
This is a bold and a statesmanlike programme. If a serious, cautious, and continued effort had been made to carry it out, the subsequent history of France and of the world would not have been what they are. Other articles were to be contributed by Quesnay,Hommes, Impôt, and Intérêt de l'argent,-but the Encyclopédie fell under the official ban in 1757 , became a secret publication, and Quesnay withdrew his co-operation. The manuscript of the article Hommes was discovered by Dr. Stephan Bauer in the Bibliothèque Nationale at Paris in I 890 . The others are lost.

The article "Grains" shows wider economic reading and deeper thought than the article "Fermiers." The text is short,- the dissertation comprehensive and far-seeing. It makes mention of Dupré de Saint Maur, the Financier Citoyen, ${ }^{1}$ D'Angeul's book referred to above (p. 3 I $n$.), Sully, Colbert, Cantillon, and Herbert's Essai sur la police générale des grains, 1755 . It contains many indications of Quesnay's later views. But before he next went into print he made, as already described, the acquaintance of Mirabeau, and it was after discussion with that writer that he printed his Tableau Oeconomique in December 1758 at the palace at Versailles. We shall find him inspiring much of the work of other men, notably the Physiocratie of Du Pont, I 767 and I 768, but except some articles in the Journal de l'agriculture in 1765

1 By J. B. Naveau, Paris, I 757, 2 vols. I 2 mo. 
and 1766 , and in the Ephémérides du citoyen in 1767 and 1768 , he wrote little more that concerns us here; and the Tableau Oeconomique may serve to explain at once the main doctrines of the master and the school.

It is necessary, however, first to return for a moment to the Essai of Cantillon. At page 55 of his Essai Cantillon begins to develop an argument of this kind. If the owners of land shut off their property and allowed no one to labour on the soil, there would be neither food nor clothing available. Every inhabitant of a state is therefore, in a sense, dependent upon the landowner. But since the latter himself desires the means of subsistence he cultivates his land, or lets it out to a farmer, who usually pays him about a third of the product for the use of the soil, retains another third for himself, as profit, and pays the remainder in wages and expenses of cultivation. Now the landlord and the farmer expend part of their shares of the product upon services and commodities furnished by manufacturers, artisans, and other members of society, who are not directly engaged in agriculture. And so it comes about that "the annual produce of the land and labour of the country," to use the later, favourite phrase of Adam Smith, becomes circulated throughout the community. But the landlords, and especially the sovereign as the largest proprietor, by their modes of living determine the economic activities of the 
nation. Industries are responsive to, and dependent upon, their demands, their humours, fashions, and style of life. These regulate the uses to which the soil shall be put, and thus determine indirectly the number of inhabitants of the state, which must be limited by the means of subsistence available. Here is the whole theory of the Tableau Oeconomique. Cantillon, with his fine eye for light and shade, characteristically adds (p. 59): "It is true that there are often in the large towns many employers and artisans who subsist by foreign trade, and therefore at the expense of landowners in foreign parts; but at present I am considering a state only with regard to its own produce and its own industry."

The practical economic problem of contemporary France, as it presented itself to the mind of Quiesnay, was of this character. Here is a country, abounding in natural resources, but production is starved in its infancy for lack of capital. Yet capital is only to be obtained by setting it aside out of the fund created by production. If this fund be turned into channels where it is not available for utilisation as producer's capital, the nation is doomed to sterility. How then is wealth distributed throughout the different classes of the nation, and how is a larger portion of it to be diverted from immediate consumption to the benefit of future production? It was clear to him that luxury and extravagance had reached a pitch at which the nation was rapidly impoverishing 
itself, living above its means and consuming not only its revenue but its capital. To make this intelligible at a glance he designed a chart or table which, so far as rapid intelligibility is concerned, is a ludicrous failure. It occupies one quarto page, and consists of three columns, headed respectively Dépenses productives relatives à l'Agriculture, etc., Dépenses du Revenu, and Dépenses stériles relatives à l'Industrie, etc. He assumes that agriculture "as in England" produces a net product (produit net) or net profit of I OO per cent (in other words a rent of cent per cent) over and above all the expenses of production including farmers' profits. Taking the hypothesis of an employment of 600 livres of capital a year (avances annuelles) in agriculture he attempts to track out the fate of the resulting rent year by year. First of all it goes to the landlord, who spends (it is assumed) half in agricultural produce and half in other expenses (dépenses stériles); and the 600 livres by dotted lines are conveyed, as by divergent streams, from the central column, one-half to the left and onehalf to the right. The 300 livres which go to the left are again applied to agriculture, and again yield a rent of I oo per cent, or 300 livres (centre column), which is again divided right and left, admitting of a further investment of I 50 livres to agriculture, and so on continually. Meanwhile the wealth which has found its way annually to the right of the table in payment for manufactures, lodging, clothing, interest of money, 
domestic servants, cost of transport, foreign commodities, and generally for everything except the conduct of extractive industry, is divided annually into two portions which are assumed to be equal, of which one is re-expended upon raw material or products of the soil, and is thus reconducted by dotted lines to the column on the left; the other half is consumed "unproductively." This zic-zac, as Quesnay calls it, was as significant as Lord Burghley's nod in Sheridan's play of The Critic. Whole volumes of political economy were read into it. In a well-known paśsage, quoted by 'Adam Smith, ${ }^{1}$ Mirabeau refers to it as follows: "There have been since the world began, three great inventions which have principally given stability to political societies, independent of many other inventions which have enriched and adorned them. The first is the invention of writing, which alone gives human nature the power of transmitting, without alteration, its laws, its contracts, its annals, and its discoveries. The second is the invention of money, which binds together all the relations between civilised societies. The third is the economical table, the result of the other two, which completes them both by perfecting their object; the great discovery of our age, but of which our posterity will reap the benefit." ${ }^{2}$

1 Wealth of Nations, bk. iv. ch. ix.

2 The original, rather freely translated by Adam Smith, will be found in the Philosophie Rurale, I763, vol. i. p. 19. 
The Tableau is followed by twelve pages of "explanation," and this again by a restatement of the Tableau without the crossed and dotted lines. Next come four pages of maxims, twenty-three in number, headed Extrait des Oeconomies Royales de M. de Sully. The "explanation" points out that the effective production of the country turns upon the extent to which the left-hand column is alimented. If a large portion of wealth is annually absorbed by the right-hand column without finding its way back to the left, the national dividend is reduced. "Hence it is seen that excess of decorative luxury may very promptly ruin by magnificence an opulent state." As Voltaire says, when writing a few years later against the Physiocrats, luxuries and new wants were intensifying a refined misery. "Nous sommes pauvres avec goît." 1

Given a wise employment of capital such as is assumed in the table, and granting, as is also assumed, that horses everywhere replace oxen in cultivation, it is estimated that the total capitalised wealth of the country should amount to some 59,000,000,000 of livres, or, allowing for a margin of error, from 55,000 to 60,000 of millions. But all this is conditional further upon the absence of eight great obstacles, - the principal causes of decay of an agricultural nation. These are :-

1 L'homme aux quarante écus, p. I. 
I. Bad forms of taxation, bearing upon the capital of cultivators.

2. Excessive cost of collection of taxes.

3. Excessive luxury of decoration.

4. Excessive expense in litigation.

5. Lack of export trade in raw materials.

6. Lack of freedom $(a)$ in internal trade in raw materials and $(b)$ in cultivation.

7. Personal harassing of the country people.

8. Lack of return of the annual produit net to the category of,productive expenses.

The pretended extracts from the Oeconomies royales of Sully are really the Maximes of economic government of the article "Grains " further worked up and developed. They are too succinct to be stated without full quotation and explanation, and only the gist of them can be given in the course of a further brief summary of Quesnay's views. An able commentary upon them will be found in the excellent little volume of Lavergne. Certain bold maxims or principles of government had indeed been laid down by Sully, the favourite minister, chief agent, and almost sole adviser of the most pepular monarch who ever sat on the throne of France; and there was in truth much affinity of spirit between the reforming zeal and the predilection for agriculture which characterised alike Sully and the Physiocrats. But it is hardly doubtful that a further motive with Quesnay was his desire to place himself under the ægis of the great rulers of the state in a glorious 
past. To refer again to the Abbé de Saint-Pierre for comparison,- - the Abbé's Projet de paix perpétuelle, 3 vols., I 7 I 3, was abridged and published in I 728 as: Abrégé du projet de paix perpétuelle inventé par le roi Henri le Grand, etc. To claim the sanction of Henri IV. and of Sully was to disarm much opposition. And as Sully had declared labourage et pâturage sont les deux mamelles de la France, so Quesnay too devised an apophthegm for the motto of his Tableau,- - pauvres paysans, pauvre royaume; pauvre royaume, pauvre roi. His desire was to publish the Tableau in the official Mercure de France, but the tactful Pompadour dissuaded him, foreseeing that the form of the Tableau would expose it to ridicule, such as it encountered at the merciless hands of Linguet in $177 \mathrm{I} .^{1}$ It was, therefore, privately printed in the royal palace of Versailles in December $1758 .^{2}$ Only a few proofs were struck off, and until 1890 it was believed to be extinct, but in that year a copy of it, slightly revised by Quesnay for further proof, was discovered by Dr. Stephan Bauer among the manuscripts of Mirabeau in the Archives Nationales at Paris; and this copy has been reproduced in facsimile by the British Economic Association in honour of Quesnay's bicentenary in 1894 . In I760 Mirabeau printed the Tableau with some modifications in the sixth

1 See post, p. I 22, and Note B, Appendix.

2 The tradition that the king helped to print it must be dismissed as mythical. See Note A, Appendix. 
part of his L'Ami des Hommes, and again in 1763 in the Philosophie Rurale, and in 1767 in the Eléments de philosophie rurale. In June I766 Quesnay published an Analyse du Tableau Économique in the Journal de lagriculture, du commerce et des finances; in November I 765 Objections contre le Tableau économique, and in January I 766 Réponse aux objections, both in the same journal. Quesnay's analysis of his Tableau appears also in the Physiocratie (November I 767), dated Leyden, I 768. Baudeau's Explication du Tableau in the Éphémérides, I767, Quesnay's Maximes, I775, and the reprints of Forbonnais, Linguet, Daire and Oncken complete the list of reproductions.

We come now to consider Quesnay's views with regard to taxation. Identifying wealth with material objects he opines that the only industry productive of wealth is that which produces raw material. The labours of artisans and craftsmen may be productive of refinement and utility, but do not add anything to the stock of wealth, for they merely change the form of existing material, and the enhanced value of the object upon which their work is expended is simply the equivalent of the payment for their services. In other words, agriculture alone yields a rent (produit $n e t)$; manufacture yields none, and is stérile-an unfortunate and ill-chosen expression which did the Physiocrats much mischief. The statesman's aim should be to meet the national expenses out of 
national revenues, without trenching upon capital. But as the produit net is the only true revenue, so should it be the only corpus to be taxed. All taxation of persons or of manufactured articles must eventually be paid out of this fund. Simplicity, justice, and economy alike, therefore, require that the taxes should be collected at their source. A single, simple, direct tax (impôt unique) should be levied upon land, and should not exceed one-third of the produit net. Landowners and farmers will adjust their burdens by raising the price of raw materials, every consumer of which will thus pay a share of taxation with the minimum of expense for cost of collection, and the whole cumbrous apparatus of existing fiscal machinery will be swept away. To sum up, the Tableau prescribes wise consumption (individuals, classes, and nations should direct their expenditure so far as possible into "productive" channels), taxation (which must fall eventually upon the land) should be directly levied upon, and should not exceed a small proportion of, the annual net production of the soil, and freedom should be allowed to individuals to prosecute the production and circulation of wealth free from let or hindrance on the part of Government.

So much for the economic and financial bearings of Quesnay's teaching. The philosophical foundation on which it seems to rest will be found in his other writings, especially Le Droit Naturel, which is included 
- in the Physiocratie. Every man, he urges, has a natural right to the free exercise of his faculties provided he does not employ them to the injury of himself or others. This right to liberty implies as a corollary the right to property, and the duty of the state to defend it,-in other words security. The guarantee of security is indeed the sole function of the state. To extend it would be to encroach on individual liberty. The state cannot be too strong for this purpose,-any constitutional checks and balance of power would but weaken the central authority. The despotism of the state is to be tempered only by enlightened public opinion, which will revolt against any infraction of natural law, or rather render it impossible. The Dauphin once bemoaned to Quesnay the difficulty of the kingly office, which he was not destined to live to assume. "I do not see," said Quesnay, "that it is so troublesome."- "What then," asked the Dauphin, "would you do if you were king?"- "Nothing."- " Then who would govern?" and the laconic answer was, "The law." On another occasion a courtier, seeing the king wearied with the disputes of clergy and parliament, proposed violent measures: "It is the halberd which governs the kingdom." - "And pray, sir," asked Quesnay, "who governs the halberd?" His adversary was reduced to silence. "It is opinion," added the doctor: "therefore it is upon opinion that you must set to work." 
In Professor Hasbach's opinion Quesnay based his economic vicws upon a deductive system of philosophy derived from the English writers, Shaftesbury, Locke, and Cumberland. Like them, he appeals to the Law of Nature, but unlike his predecessors (with the exception of Grotius, who had declared for free trade) he extends its sphere beyond religion, politics, and individual life, to the realm of political economy. As Locke was the father of political individualism, so Quesnay was one of the fathers of economic individualism; and his real originality lies in his organic thenry of economic life. ${ }^{1}$ It might be argued . that his economic principles were buttressed by, rather than deliberately founded upon, his philosophy; but in the hands of Mercier de la Rivière and others it undoubtedly took on more and more of a philosophical form.

In I 758 Quesnay drew up a table of motives, ${ }^{2}$ 4 pp., 4to, somewhat resembling the later work of Bentham, and printed it at Versailles about the same time as the Tableau Oeconomique, with which it is uniform in type, paper, and form. 'The only copy which I have ever seen is in the library of Professor Foxwell at Cambridge, bound up in a volume once the property of Adam Smith, who wrote the

1 Die alloemeinen philosophischen Grundlagen, etc., I890, pp. 59, 67.

2 A footnote refers to Malebranche, cf. supra, p. $27 n$. French economists have shown great fondness for synoptic tables, from Vauban to Fourier. 
name of Quesnay against it in the title-page. It is entitled Observations sur la psychologie, ou science de l'âme. The versatility of Quesnay's genius is further attested by several writings upon mathematics, ${ }^{1}$ and in his extreme old age he believed he had solved the problem of squaring the circle. Some analogous belief he may well have held as to the originality and unshakable accuracy of his speculations in economic and financial science; for the exaggerated eulogies of his followers were enough to turn the head of the most modest of men. Exacting from each of his disciples an undertaking not to refer to him by name, and publishing his own views on economics under the anagram of Nisaque, M. H., M. N., M. Alpha, M. de l'Isle, anonymously, or under the sole name of some collaborator, he was the victim of much hyperbolical periphrase for which Mirabeau was usually responsible. He was in turn "the greatest genius of our age," "the Confucius of Europe," "the Socrates of our day," "the Moses of modern times." Well might Adam Smith say of the Physiocrats, "The admiration of this whole sect for their master, who was himself a man of the greatest modesty and simplicity, is not inferior to that of the ancient philosophers for the founders of their respective systems." ${ }^{2}$ He was not without honour in Englan'.

1 E.g. Véritís géometriques, Amsterdam, 1773.

2 Wealth of Nations, bk, iv. ch. ix. 
The Royal Society elected him a Fellow. ${ }^{1}$ On the death of Louis XV. he lost his Court favour, lived just long enough to see Turgot's accession to power and commencement of reforms, but died at Versailles the same year, I6th December I 774, before the fall of Turgot, and before the appearance of the Wealth of Nations (both in 1776) which it had been Adam Smith's intention to dedicate to this "very ingenious and profound author," the "modest and simple" founder of the physiocratic school. ${ }^{2}$

1 28th May 1752, before he commenced writing on economic subjects. Mr. Robert Harrison, assistant secretary of the Royal Society, informs me that his candidature was backed by Buffon, Walmesley, D'Alembert, La Condamine, Grand Jean de Fouchy, Sallier, Bernard de Jussieu, Lieutaud; and W. Watson, Samuel Sharp, N. Munckley.

2 A statue of Quesnay has, since the date of this lecture, been erected at Méré, where he was born. There are several portraits of Quesnay in existence. To one of these Dr. Hodgson owed his interest in economics. See his lectures on Turgot, London, 1870, p. 66. 


\section{III}

THE artist has not yet arisen who has chosen to paint a great historical picture of the scene which M. de Loménie ${ }^{1}$ describes as follows :-

"On the 2oth December I774, amidst the enthusiastic hopes to which a new reign gave birth, five months after Turgot's entrance into the ministry, a considerable number of persons, attired in mourning, were gathered in the principal room of a townhouse in the Rue Vaugirard [at Paris]. At the end of the room had been placed a large pedestal surmounted by a marble bust, and the whole assembly being turned towards this bust in an attitude of sorrow and respect, the master of the house pronounced a speech of a rather odd character, especially for the epoch." "Gentlemen," began the orator, "we have just lost our master; the veritable benefactor of humanity belongs to this earth only by the memory of his good deeds and the imperishable record of his

1 Les Mirabeau, vol. i. p. 335. 
achievements." He goes on to declare that Socrates ${ }^{1}$ had been said to have drawn down morality from heaven. Their master had done more, he had made it germinate upon earth. Religion was a solace and a ruling power only to a few elevated souls. The terrestrial guide of conduct based upon the produit net appealed to the reason and intelligence of every man, persuading him by the enlightened pursuit of selfinterest to promote the welfare of mankind at large. The speaker, now left, he says, the leader of the band, appeals to his hearers to carry on their immortal founder's work, and further the progress of "the science which shall one day render societies peaceful and prosperous, and men reasonable and virtuous." And he concludes by apostrophising the bust on which they gazed: "O venerable bust, that represents to us the features of our master," ${ }^{2}$ etc. The silent bust which looked down upon this somewhat theatrical mise en scene was that of Quesnay. The extravagant and stilted eloquence, its pomp redeemed by sincerity and affection, was the characteristic language of the Friend of Humanity, the Marquis of Mirabeau, refraining, even now, with pious fidelity, from speaking

1 The Physiocrats pretended that Quesnay resembled Socrates in personal appearance. A lady-in-waiting to Mme. de Pompadour, Mme. du Hausset, whose Mémoires furnish some biographical details of the doctor, respected his probity and his learning (which she did not understand), but irreverently calls him a monkey-face !

2 The speech, which was printed in the Nouvelles Éphémérides, I 775, vol. i., may be read in Oncken's Quesnay, pp. I sqq. Another éloge of Quesnay was published in vol. v. the same year, by the Comte d'Albon. 
the doctor's name. We can guess who were many of the disciples gathered round, but none of them was so popular or authoritative an exponent of physiocracy as Mirabeau himself, and several of them were his own proselytes. His indefatigable industry and ardent zeal had spread the fame of the Physiocrats and their system through all the countries of Europe. ${ }^{1} \mathrm{He}$ brought to the service of Quesnay in 1757 a literary reputation already firmly and widely established, a considerable amount of social influence, and valuable resources of time and energy, as well as of money. The history of his family-a "tempestuous race," he himself confesses - is, as recounted by M. de Loménie, one of the most striking and fascinating in the whole range of biographical literature, and is not without importance for the student of his works. He was born on the 4th October I 7 I 5 , the year of the death of Louis XIV., and died on the I 3 th July I789, the day before the storming of the Bastille. His life thus coincides with what is usually regarded as the inception and the triumph of the French Revolution. After serving with bravery in the army, he succeeded, in 1737 , when only twenty-two years of age, to his father's title and estates, and gave up the profession of arms. He seems early to have cherished the ambition of becoming a great philosophical statesman, and of aggrandising the honour

${ }^{1}$ He says of Quesnay, "I, like posterity, owe everything to him. He owes me nothing but his repute." And de Loménie justly adds, "In effect he did owe it to Mirabeau." 
and power of his own family. He married a wife whose great expectations, her only recommendation, became a veritable apple of discord. When her unspeakable misconduct, approaching - if not overstepping - the bounds of madness, and the sensational follies of his famous but dissolute and spendthrift son, wounded his family pride, he acted with the despotism of a Highland. chief smarting under a sense of dishonour to his clan. But in 1757 these troubles were yet to come. He had been the friend of Vauvenargues and an acquaintance of Montesquieu. The system of government appeared to him hopelessly unsuited to the needs of the nation, and far better than most of his contemporaries he saw the real power which lay dormant in the people-the force of numbers. "He was," says Victor Hugo, "at once in advance of and behind his age." "He presents in himself," says de Tocqueville, "the spectacle of a feudal character invaded by democratic ideas." He had argued in the first part of L'Ami des Hommes for a multiplication of small peasant proprietors; but he allowed Quesnay to persuade him that the true ideal was the maximising of the produit net of the country, which was to be better achieved by an economical exploitation of land on the larger scale. He had also urged, following Cantillon, that imports of corn should be encouraged and exports discouraged; but, as we have seen, this too was in opposition to Quesnay's views, for the 
doctor considered such a course, in the long-run, inimical to a large food supply, since low prices of corn would discourage its national production. But while giving way upon these points he remained the most independent member of the school. Utilising the popularity acquired by L'Ami des Hommes, he proceeded, after allying himself with Quesnay, to publish continuations of the work (part 4 , no imprint, 4 to and I $2 \mathrm{mo}, \mathrm{I} 758$; parts 5 and 6 , do. do., I760), making a whole of three quarto or six duodecimo volumes. In these later parts the cooperation of Quesnay is evident. Part 4 contains a Dialogue entre le Surintendant D'O. et L.D.H., a reprint of the Mémoire sur les Etats provinciaux, with a reply to an anonymous criticism of Naveau's, and a series of (separately paged) Questions intéressantes sur la Population, l'Agriculture, et le Commerce proposées aux Académies et autres sociétés sçavantes des Provinces, asking for local information upon agricultural conditions, and also suggesting some general considerations somewhat in the style of Berkeley's Querist. These questions, the reader is informed, are not by the author of the Mémoire sur les Etats provinciaux. ${ }^{1}$ The 5 th part contains the essay which Mirabeau had written for the prize of the Berne Agricultural Society in 1759 , on the reasons why Switzerland should give preference to the cultivation.

1 Du Pont says by Quesnay, Éphémérides, I768, vol. ii. p. I9I. Daire says by Quesnay and Marivelt, Physiocrates, vol. ii. p. 340 . 
of corn. The essay is followed by extracts from the first six books of an English work (translated from T. Hale's Compleat Body of Husbandry, 1756). The 6th part consists of a Réponse à l'Essai sur les Ponts et Chanssées, La Voierie, et Les Corvées, and of the Tableau Oeconomique avec ses explications. In the same year with this later part, I 760 , appeared his Théorie de l'Impôt, 4to and I $2 \mathrm{mo}$, without imprint, which immediately had an enormous vogue. It was a spirited and able attack upon the financial administration of the country, and especially upon the farmers-general, whom Mirabeau regarded as parasites preying upon the vitals of the nation. ${ }^{1}$ The taxgatherer is never a welcome visitor, even when he is the direct representative of local or central authority ; but when he presents himself in the guise of a speculator whose personal profit or loss turns upon the amount of taxation he can collect, whose agents have no bowels of compassion, no willingness to hear or ability to accept excuse or appeal, and who violate the public conscience by relentless severity, while their employer is seen to be making a considerable fortune at the public expense, then indeed an outcry against him will awaken innumerable echoes, and the Théorie de l'Impôt spread like wildfire. "Seigneur," begins the author, with address to the king _- "Seigneur! you have 20,000,000 of subjects,

1 If ther had lost 200,000 livres in the "system" of Law, and he always held financiers in abhorrence. 
more or less, ${ }^{1}$ all with a little money, and almost all capable of rendering you such service as you require ; and yet you can no longer obtain service without money, nor money to pay for service. In plain language your people are holding back from you, without knowing it, for they are still well disposed to your person even though they be not to the agents of your authority." And he puts into the mouth of the king the soliloquy that his position as the head of his people is justified only so long as, and only because, he costs them less than he is worth to them. This remorseless test, "Are you worth what you cost?" must have been like acid to a raw wound, for the colonial empire was falling to pieces, and within a year the French had been driven out of Canada and of India. He makes the king add: "Where my people loses its rights, there is the limit of my empire." Taxes are really of the nature of voluntary offerings rather than forced contributions. The sovereign has not the right to tax his subjects without their participation and assent, and the collection of taxes should be handed over to the representatives of the people themselves. ${ }^{2}$ The powerful financial interest, fastening upon such passages, where exhortation is mingled with barely-

1 Quesnay's article "Grains" had put the number at 16,000,000; see p. 34 supra. Mirabeau probably here makes a concession to Messance, whose Recherches sur la population, I 766, was designed to refute $L^{\prime} A m i$ des Hommes, so far as it alleged depopulation.

2 See p. 20 supra. 
veiled menace, denounced the Ami des Hommes to the king, who caused him to be imprisoned (I 6 th December I 760) in the chateau of Vincennes, which was afterwards to receive the author's son. The anger of the king was mollified by Madame de Pompadour ${ }^{1}$ and Mirabeau's friends, and on Christmas Eve he allowed him to be liberated under orders to reside at his property at Bignon and not in Paris. This sharp reminder of the limits of freedom kept the Physiocrats silent, though not inactive, for stwo and a Half years. In 1763 Mirabeau made a convert of Du Pont de Nemours, who, writing in I 769 of the Théorie de l'Impôt, says : "This sublime work has, to my knowledge, been multiplied by eighteen editions." Beyond the abolition of the practice of farming out the taxes it recommends reforms in the direction of making taxation lighter, simpler, and more direct. It urged that the tax on salt should be reduced, with the object of increasing the total yield (a recognition of the principle, now well known under the name of the elasticity of the exchequer), that there should be a special tax upon tobacco-farms, and that apart from the Post Office, the Mint, and the Domaine (crown lands and crown dues) the rest of the national revenue should be derived from a tax upon land. This is the Impôt unique with modifications. The work contains many valuable remarks,

1 She had little sympathy with Mirabeau himself, but was much attached to Quesnay, who had twice saved her life. 
and is of real importance in the history of financial theory.

In I 763 appeared the Philosophie rurale, Amsterdam (Paris), 4to, which presents perhaps the most complete and magisterial account of the views of the physiocratic school, and was called by Grimm "the Pentateuch of the sect." Daire, who shows little sympathy for Mirabeau, declares it to be "the best, or rather the least bad, of all his works"; but he would have expressed himself more respectfully had he known the large share taken in the work by Quesnay, who, according to Du Pont, inspired it and wrote the whole of the seventh chapter himself. ${ }^{1}$ An abridgment of it, under the title Éléments de philosophie rurale, was published in $\mathrm{I} 2 \mathrm{mo}$ at The Hague in 1767 . Of his other works it is sufficient to mention Réponse du correspondant à son banquier, I 759, 4to (a reply to Forbonnais); Lettres sur le commerce des grains, Amsterdam and Paris, I768, I $2 \mathrm{mo}$; Les Économiques, Amsterdam and Paris, I 769-72, 2 vols. 4to, or 4 vols. I 2 mo; Lettres d'un ingénieur. . . pour servir de suite à l'A mi des Hommes, Avignon, I770, I $2 \mathrm{mo}$; Lettres Économiques, Amsterdam, I770, I 2mo; Les Devoirs, Milan, I770; La science, ou les Droits et les Devoirs de l'homme, Lausanne, I774, I $2 \mathrm{mo}$; Lettre sur la législation, Berne, I775, 3 vols. I $2 \mathrm{mo}$; Supplément à la théorie de

1 Du Pont de Nemours et l'Ecole physiocratique, par G. Schelle, Paris, I888, 8vo, p. 25. 
l'impôt, La Haye, I776; Entreticn d'un jeune Prince avec son gouverneur par L.D.H. Publié par M.G. . . . [l'Abbé Grivel], Paris, I 785,4 vols. 8 vo and I $2 \mathrm{mo}$; Education civile d'un Prince, Doulac, I788, 8vo; Rêve d'un goutteux, ou le Principal (end of I788), an octavo pamphlet, his hopes of the Constituent Assembly about to meet-and Hommes à célébrer pour avoir bien mérité de l'humanité par leurs écrits sur l'Économie politique. Ouvrage publié par P. Boscovitch, ami de l'auteur, Bassano, 2 vols. 8vo. Many of these works were announced as by L.D.H. ( $L^{\prime} A m i$ des Hommes), but the later ones appeared sometimes anonymously and in foreign countries by the care of his friends. Les Devoirs had been seen through the press by the Marquis of Longo, professor of political economy at Milan. It urged that, in the interests of society, men should receive economic instruction as a guide to conduct. And so elementary education should be compulsory, and even free where the recipient cannot afford to pay.

It is sometimes supposed that the French Revolution destroyed the influence of the Physiocrats. But in truth their reputation in France had in 1789 long been on the wane. The year I 776 struck it three blows from which it never entirely recovered. 1 The fall of Turgot, though he is not strictly to be reckoned as one of the sect, paved the way to their discomfiture. 2.The publication of the Wealth of - Nations more slowly but effectually destroyed their 
authority by sapping the scientific basis on which it reposed. And finally, in 1776 , began the scandalous dissemination of lies and libets by Mirabeau's wife and children which shook the Friend of Men from his pedestal of popularity, and dragged him through the mire as a hideous impostor, whose private life, at hopeless variance with his public precept, would show the teacher of morality unmasked as a monster of hypocrisy. In his well-known Lettres de Vincennes the younger Mirabeau ridicules the Physiocrats, and does not spare their chief: "It will sooner or later be seen," he says, "that my father owes only to his own generosity the title of L'Ami des Hommes . . a a man who calls himself tender, compassionate, the legislator of kings, the benefactor of humanity at large, and is the oppressor of his wife and children." "I know," whines the young profligate, "that appearances are against me. But so they are against my father, who imprisons me. Facts can be so easily distorted. It might, for instance, be said that he had ruined himself in creating a political economy; that he had compromised two millions of the fortune of his wife and children, while protesting against luxury and debts; that he had persisted in founding a sect at Paris and living there to the detriment of his means while declaiming vigorously against absentee landlords; and that after denouncing lettres de cachet in his writings he had employed fifty-three of them against his wife 
and children, of whom all but one are under lock and key." "No doubt," he suggests, "my father could defend himself against all these charges. Why, then, will he not hear a defence from me?" The labours of M. de Loménie, exposing the prejudice and misrepresentation of $\mathrm{M}$. de Montigny, have rehabilitated in great measure the economist's reputation, and in his later years the orator of the Revolution rallied to his father's side and loaded him with praise and respect. But it concerns us to note that the immediate effect of these attacks was, on the one hand, to weaken the elder Mirabeau's popular repute, while, on the other, they drove him to absorb himself more and more in economic writing as a distraction from his family troubles. He left 400 quartos in manuscript written by his own hand, forty published volumes, several contributions to journals, a number of unpublished writings, and an immense correspondence, exchanging upwards of 4000 letters with his brother alone. Other branches of his activity will be mentioned in the next chapter. "Had my hand been of bronze," he said in his old age, "it would long since have been worn out."

Among the "persons attired in mourning" who "turned towards the bust of Quesnay in an attitude of sorrow and respect," there was one notable gap. There was a vacant place for an eminent young disciple returning from Poland to serve with Turgot, Du Pont de Nemours (b. I 8th December I 739, $d_{*} 7$ th 
August 1817 ), who, converted by Mirabeau in 1763 , became the amiable hard-working hack of his masters, editing the works ofQuesnay (the Physiocratie, I 767-8), and the economic Journals of the school, besides becoming the secretary, biographer, and friend of Turgot, a trusted adviser of foreign princes, and finally a member of the Constituent Assembly. The bibliography of his own writings, appended to M. Schelle's excellent monograph, contains I I 2 separate entries in addition to new editions and translations, and one of these entries alone covers some I 20 articles in the Éphémérides, while others embrace a number of separate writings. In 1763 the nation stood, at the conclusion of the Seven Years' War, literally bankrupt. The question of finance was one of life and death. An anonymous pamphlet, $L a$ Richesse de l'Etat, I $7 \sigma_{3}$, 8vo, written by a state official, Roussel de la Tour, proposed to replace all taxes by a progressive poll-tax. Du Pont, then twenty-three years of age, criticised it in a pamphlet entitled Réflexions sur la Richesse de l'État. Taxes - really fall, he says, on the land, and should be levied directly on landowners. This pamphlet interested Quesnay and Mirabeau (whose exile to Bignon had not yet been cancelled) for two reasons. They found in it a statement of their own doctrine; and they concluded, since the Government allowed it to circulate, that they might venture to renew their own activity. Mirabeau's exile was now soon brought to 
an end. Du Pont was invited to one of Quesnay's meetings in the entresol of Mme. de Pompadour, and was definitively recruited as a member of the school the same year, I763. "Let us have a care of him," said Quesnay to Mirabeau ; "he will speak when we are dead." On the 25 th May 1763 , the edict of 1754 , permitting internal freedom in the corn trade, was re-enacted with extensions; nobles might trade in corn without derogation, and corn was to be free from tolls for transport. The edict was suspended by Terray in I770; but on Turgot's accession to office in 1774 , his first act was a still more liberal edict permitting virtual freedom of export and import - the preamble, drafted by $\mathrm{Du}$ Pont, following very closely the views of Quesnay in his article "Grains.". The new policy was designed, says the edict, " to animate and extend the cultivation of the land, whose produce is the most real and certain wealth of a state, Jto maintain abundance by granaries and the entry of foreign corn $; \dot{b}^{\circ}$ to prevent corn from falling to a price which would discourage the producer, ${ }^{\prime}$ to remove monopoly by shutting out private licence in favour of free and full competition; Tand by maintaining among different countries that communication of exchange of superfluities for necessaries which is so conformable to the order established by Divine Providence." The Physiocrats appeared to have gained a large part of their cause. But they recognised that it was 
necessary, in Quesnay's phrase, to "act upon opinion." Popular prejudice feared that rings and corners would force up the price of corn to famine point for private profit by sending it abroad. It was necessary to educate the public upon the safeguards which "the obvious and simple system of natural liberty," as Adam Smith called it, carries within itself; and the Physiocrats therefore sought for a journal in which they might circulate their ideas. Such a journal they found in a supplement to the Gazette du Commerce, founded I 763 , entitled Journal de l'agriculture, du commerce, et des finances, of which $\mathrm{Du}$ Pont was appointed editor in September 1765 , probably on the recommendation of Trudaine. ${ }^{2}$ The proprietors, instigated by the opponents of the school, ${ }^{3}$ dismissed him after the issue of the November number, I 766 , and the economists were obliged to find another organ. The Éphémérides du citoyen, ou Chronique de l'esprit national, a bi-weekly paper, had been founded in I 76.5 by the Abbé Baudeau on the model of our Spectator. The Abbé defended the mercantile system, but admitted articles criticising his views, and to one such article by Le Trosne he proposed to reply in nine articles, the first of which he sent to Du Pont's Journal in I 766. Du Pont published it, with some annotations. "You argue," he said, "that

1 See p. 45, supra.

2 According to Schelle. De Loménie tells us it was due to Morellet.

3 But cf. post, p. 81, probably a more accurate account. 
nations grow rich or are ruined according to the balance of foreign trade. But surely you will admit that a nation may have no foreign trade and yet be ruined. How does your theory account for this?" Baudeau visited Du Pont, discussed the matter, said he had found his road to Damascus, and threw in his lot with the Physiocrats. The Éphémérides suspended publication for two months, and in January I 767 reappeared with a new sub-title, Ephémérides $d u$ citoyen, ou Bibliothèque des sciences morales et politiques, a monthly duodecimo. In May I 768 Baudeau received ecclesiastical preferment in Poland. Du Pont, now employed in Limousin with Turgot, sacrificed. his position to come to Paris and take over the post of editor, which he retained till the Journal was. suppressed by Government (November I 772). The Margrave of Baden next appointed him Privy Councillor, and drew him to Carlsruhe, where he remained until (July I 774) he started for Poland to serve as tutor to the son of Prince Czartoryski. Arrived in Poland, he heard from Turgot of his accession to the ministry, and was offered a place, which he did not feel justified in accepting immediately. In September, however, Turgot formally nominated him inspector-general of manufactures, and $\mathrm{Du}$ Pont rendered Turgot valuable service till they fell together in I776. The Mémoire sur les municipalités, Turgot's plan of reform in local government, was the work of his pen; and when Turgot 
died in $178 \mathrm{I}$ he wrote an account of his life and writings ( 1782 ), and many years later edited his works in nine octavo volumes (I809-I 8 I I). In I 782 he negotiated with England the treaty recognising the American Independence. In I 786 he was entrusted with the negotiation of the commercial treaty with England. In 1787 he took part in the Assemblée des notables. In 1789 he was elected to the Constituent Assembly, ${ }^{1}$ struggled for freedom and for an economic policy, opposed the assignats and the Jacobins, and, after running many dangers, in 1793 voluntarily exiled himself to America. He came back in $\mathrm{I} 802$, and took office under Louis XVIII., but with the return of Napoleon he again quitted France for America, where he spent the two remaining years of his life.

So much of history and biography is necessary to the comprehension of the march and influence of the physiocratic school. Of Du Pont's other writings space does not permit mention. Many of the articles written by himself and others in the Journal and the Ephémérides appeared as separate publications. The Physiocratie, I $767-8,{ }^{2}$ consisted of several

1 As a representative of Nemours. There was another Du Pont in the Assembly. This led to his being distinguished as Du Pont de Nemours. He acted for some time as President of the Assembly.

2 The title of this volume, designed to indicate "government in consonance with nature," is accountable for the name Physiocrats which J. B. Say, conferred upon the school, known to their contemporaries as Economistes. Du Pont has long been regarded as the inventor of the title, but there is more reason for the belief that it was due to Quesnay. 
such articles by Quesnay, edited by Du Pont, and a pamphlet of I768, De l'origine et des progrès d'une science nouvelle, has for many years been the fountain of the history of the Physiocrats. ${ }^{1}$ It is now seen to contain numerous inaccuracies, some of which are due to Du Pont's anxiety to repel the sectarian charge which had been urged against the school. To him all economists worked together,-their differences were less important than their points of agreement. "You are an economist like ourselves, my dear Say," he wrote to J. B. Say at the end of his life, when the French Adam Smith had tried to dissociate himself from the school of Quesnay. And in sketching the origin of the school he declared that Quesnay and Gournay were its two founders. Of Gournay, pending the publication of Professor Oncken's volume, little more is known than is contained in the Eloge of his friend Turgot (1759). $\mathrm{He}$ was born in 1712 , engaged in commerce at Cadiz (I 727-I 744), travelled over Europe (I 744I 75 I), came back to France, was made an intendant of commerce (175I), and went about the country, taking Turgot with him on some occasions, on his

1 It was really an endeavour to present to the public at Diderot's suggestion a succinct account of Mercier de la Rivière's Ordre naturel et essentiel des sociétés politiques, 1767, I vol. 4to, 3 vols. 12mo. M. Schelle imagines that Adam Smith may have mistaken it for the larger treatise, which he calls " a little book." Adam Smith was, however, too well acquainted with the Physiocrats to make a mistake of this kind; and we know that he possessed the work of Mercier de la Rivière himself. See Economic Joumal, vol. iv. p. 706 (Dec. 1894). 
visits of official inspection. He chafed at the trammels which harassed trade, recommended the study of economics, especially the writings of Cantillon, Tucker, Culpeper, Child, ${ }^{1}$ and other English authors, and was in favour of internal free trade and of light customs duties. He died in I 759, held few of the peculiar doctrines of the Physiocrats with regard to land and taxation, and it is doubtful whether he ever had any personal acquaintance with Quesnay himself. Du Pont attributes to Gournay the origin of the famous maxim Laissez-faire, Laissez-passer, which Gournay indeed seems to have popularised. But a study of Turgot's Éloge de Gournay shows that the expression Laissez-faire is really due to Le Gendre, a merchant who attended a deputation to Colbert about I680 to protest against excessive state regulation of industry, and pleaded for liberty of action in the phrase "Laissez-nous faire. ${ }^{2}$ Boisguillebert and D'Argenson had used it also before Gournay, who may, however, be said to have made it classical in its later form. His personal influence stimulated many persons, notably Turgot; and Du

1 He translated Child and Culpeper into French. See supra, p. 15.

2 See Professor Oncken's Die Maxime Laissez-faire et Laissezpasser, ihr Ursprung, ihr Werden, Berne, 1886. The erudite professor of history, Lord Acton, in his introductory lecture at the University of Cambridge, refers to " the economic precept Laissez-faire, which the eighteenth century derived from Colbert" (The Study of History, I895, (p. 30), and quotes from the Comptes rendus de l'Institut, vol. xxxix. p. 93, in support of this statement; but, as stated above, the phrase was really a remonstrance against the settled policy of Colbert, which was, except for the aim at economic unification of the nation, directly opposed to this precept. 
Pont mentions a number of writers as belonging to his "school" - the commercial rather than the agricultural advocates of free trade.

The next eminent Physiocrat to require mention is Mercier de la Rivière (I 720-I 794), a magistrate who filled for some time the post of Governor of Martinique, and wrote an important treatise, already referred to, L'Ordre naturel et essentiel des sociétés politiques, I 767, which Adam Smith has described as "the most distinct and best connected account of the doctrine" of the sect. It is composed in the "grand style," to which the Scotch economist was not insensible, and like many of the chief works of the school was prepared under the eye of Quesnay, though the author omits the usual eulogies of him, and moved Mirabeau to write in later years, "I have seen him at work in his dressing-gown six "whole weeks in the entresol of the doctor, casting and recasting his work, and then renounce his father and his mother." 1 [Quesnay and Mirabeau.]

In 1767 the school was still young. Daire asserts that the public had only a choice between the laconics of Quesnay and the disheartening prolixities of Mirabeau, whose oddities of style, diffusion of matter, and profusion of figures were, he says, enough to kill political economy on the spot. $^{2}$

1 Mr. John Rae has misunderstood the significance of this statement in his Life of Adam Smith, p. 2 I8.

2 Les Physiocrates, vol. ii. pp. 429, 430. 
Exception must be taken to this statement, so far as the writings of $\mathrm{Du}$ Pont and Abeille and the articles of the Journal are concerned. But it is none the less true that the Ordre naturel et essentiel was at once warmly greeted. Du Pont called it " sublime," " eloquent," "logical and closely reasoned," and the Russian ambassador, Prince Galitzin, wrote to Voltaire" that it was "far superior to Montesquieu." The followers of Colbert and lovers of stateregulation had attacked the Physiocrats from the political side. On one occasion Carl Friedrich of Baden, who had come to Paris on purpose to see his master Mirabeau, asked with naïve sincerity whether it might not be hoped that, with the spread of physiocratic knowledge, sovereigns would become unnecessary and be reformed out of existence. Mirabeau admitted that their rôle would be much restricted, but the public domains would need an owner, and his duty would be to preserve social order and encourage social instruction. The question addressed to the Physiocrats was, "If your system says 'Hands off!' to the state, and begs it to 'let things alone,' what do you consider the functions of the state to be?" Mercier de la Rivière attempts to create a philosophy of the state. Newton and others had discovered great laws governing the harmonious order of the physical world. There were surely similar laws governing

1 See p. Ior, post. 
the moral order of the social world, and the motto of the book is a sentence from Malebranche's Traite de Morale: "L'Ordre est la Loi inviolable des esprits; et rien n'est réglé, s'il n'y est conforme." The general. plan of creation had provided natural laws for the government of all things, and man could be no exception to the rule. He needed only to know the conditions which conduce to his greatest happiness to follow and observe them. All the ills of humanity arise from ignorant opposition to these laws, study of which will show that the welfare of each member of society is inseparably bound up with the welfare of others, and the attainment of this common welfare will dispose mankind to grateful adoration of the beneficent Being by whose order this perfect cosmos is maintained.

The organisation of man proves that he is a social animal, designed by nature to live in society. In this state of society there are no rights without duties, no duties without rights. The right of selfpreservation implies the right to property; but the faculties of men are by nature unequal, which gives rise to a natural inequality of conditions. Individual property in the products of the soil carries with it a physical necessity for individual property in the soil itself. Increased wealth is the mediate object of society, as a condition of increased happiness; and this happiness is enhanced by an increase of numbers, rendered possible only by additional production. 
But the right to property would be null without the liberty of using it, and social liberty is a branch of property. The natural and essential order of society is thus unarbitrary, simple, evident, immutable, and the most advantageous to the human race. It binds together prince and people in common interest, its evident character, publicly recognised, makes it socially dominant, despotic without violence. Two social institutions are necessary: (I) Magistrates, distinct from the legislature, to resolve doubts and put into execution all laws of whose justice they are satisfied and no other (to act differently would be as if a doctor should follow with his patient a course which he knows to be mortal); (2) a tutelary authority, the depositary of the public power, and enacting laws in accordance with justice (for the right of law-giving rests on the duty of not enacting laws evidently bad). This power must be single and indivisible. A so-called legislative body is not a body but a, multitude of units momentarily brought together without unity of views. If they differ, they are not all perfectly wise : if they agree, one would do as well as many, or better, since it is contrary to order that authority should be divided among many hands. The best tutelary authority is a single sovereign who can gain nothing by ill-government, but has the greatest interest in governing well. He must be hereditary, not having a mere usufruct but a fee-simple interest in the nation, co-proprietor of the produce of its 
soil. Despotism is held in horror, because we confound what it has been (an arbitrary despotism which is fatal) with what it might be (a legal despotism, which is the most advantageous form of government). In fact an arbitrary despot commands but does not govern, for as his caprice is above law, there are, under him, neither rights, laws, nor nation,-_" a nation being a political body whose members are united by a chain of reciprocal rights and duties, inseparably combining governor and governed in one common interest."

Thus far the first twenty-six chapters. The remaining eighteen are of more direct economic interest, and are the only ones printed by Daire in his collection of the Physiocrats. The sovereign, as already stated, is co-proprietor with landowners,-a partnership involving mutual rights and duties and mutual interests, - and has a share in their produit net. In the origin of society this share was at the expense of the first landowners, though even to them the kingly office was of more utility than their contribution. Subsequent holders of land have taken it subject to this royal charge, so that it has ceased to be a burden upon individuals. But if the sovereign takes more than his proper share, he injures his partners and thereby injures himself. Government exists to secure the rights of property, and any arbitrary element in taxation is not only unwise and suicidal, but essentially unjust, for it is an attack 
upon and an infringement of the very rights which it is the business of Government to protect. An invariable sum of taxation would be unfair, either to the sovereign or the landowner, for the produit net varies with the seasons. The proper form of taxation is therefore a proportional share of the produit net. From each harvest must be set aside the whole costs of production, for these are the necessary elements of new wealth, and the surplus must be divided part to the landowner, part to the king. It must be collected direct, for if it be imposed upon commodities or upon persons, its equity and incidence cease to be evident and become arbitrary, which is its condemnation, to say nothing of the expense of collection, the taxation twice over (once when the material is produced and once when it is manufactured), and the fact that part of the taxes will fall upon the sovereign himself. Every vendor is a purchaser, and every purchaser a vendor. The liberty of individuals holds as well for external as for internal trade, and the different nations should be regarded by the economist as if they all formed part of one nation. International freedom of trade would enable each nation to pursue its greatest natural advantage; and it is the interest of a single nation to adopt this view, even though it be not adopted by other nations. Industry and commerce are in themselves unproductive. A weaver buys fifty francs' worth of material, works it up, and sells it 
for 200. He has, it is said, quadrupled its value ; but this is not so. He has added to its original value an outside value, - that of I 50 francs' worth of material which he has consumed in clothing, food, etc., while engaged on his work. Addition is not multiplication. If there were no one to take the finished product off his hands, this additional value would be irretrievably lost. But if I let you an acre of land for ten francs, you spend ten more in cultivation, and obtain a harvest of thirty francs, the acre returns you your rent and your expenses, and a surplus over and above. The rôle of industry and of commerce which makes values change hand, but does not multiply them, is thus narrowly restricted, and the main economic ideal of a nation is to maximise its net products.

Adam Smith remarks of the Economistes that " in their works, which are very numerous, and which treat not only of what is properly called Political Economy, or of the nature and causes of the wealth of nations, but of every other branch of the system of civil government, all follow implicitly, and without any sensible variation, the doctrine of M. Quesnai. There is, upon this account, little variety in the greater part of their works." And then he adds the statement, already referred to (p. $66 n$.), that "the most distinct and best connected account of their doctrine" is given by Mercier de la Rivière. But La Rivière's book, which deals especially with the political side 
of their teaching, was not entirely accepted by some members of the school in its plea for an enlightened despotism. Mirabeau and Du Pont, Abeille and Morellet, for instance, while agreeing in the letter with most of these opinions, differed from them in spirit, and even, later on, in practice. As for Turgot, Mirabeau relates that $\mathrm{Du}$ Pont repeated to him Turgot's words when Du Pont was leaving for Poland : "I am not an encyclopædist, for I believe in God: I am not an économiste, for I should wish to have no king."

We shall have some glimpses of other members of the school in later chapters; but space does not admit of any such detailed account of their lives and work as it has been thought best to give of the four chief writers of the school. Mention must, however, be made of the following works as among the most important not yet referred to.

The Abbé Baudeau's (I 730-I 792) chief service to the school consisted in his editing the Ephémérides and the Nouvelles Ephemérides, to which he contributed largely. His Premiere introduction à la philosophie économique ou analyse des États policés, Paris, I77 I, deserves special attention among his separate writings, and has been reprinted in the collection of Daire.

Le Trosne (I 728-I 780), a lawyer of ability and a distinguished pupil of Pothier, is best known by a work in two volumes, the first entitled De l'ordre social, and the second De l'intérêt social, 8vo, Paris, 
I777, a clear and methodical exposition of the physiocratic system. Turgot distributed broadcast throughout his province in I765, Le Trosne's $L a$ Liberté du Commerce des Grains, toujours utile et jamais nuisible, with a covering memorandum in which he gives it the highest praise.

Saint-Péravy (I 732-I789) is remembered chiefly for his Mémoire sur les effets de l'impôt indirect sur le revenu des proprietaires de biens fonds, qui a remporté le prix proposé par la société royale d'agriculture de Limoges en 1767 , I 768, I $2 \mathrm{mo}$, Londres et Paris, which owes its fame in part to the Observations sur la mémoire de M. Saint-Péravy of Turgot, the president of the society, which he had himself founded in his province. The memoir supported the impott unique.

Abeille (I 7 I 9-I 807), secretary of the Agricultural Society of Brittany, a contributor first to the Journal and then to the Éphémérides, wrote Lettres d'un négociant sur la nature du commerce des grains, Paris, I 763 ; Réflexions sur la police des grains en Angleterre et en France, Paris, I 764 ; Principes sur la liberté du commerce des grains, Paris, I768; Faits qui ont influé sur la cherté des grains en France et en Angleterre, Paris, I 768, and other pamphlets, besides editing the Observations of his society. He became inspector-general of manufactures in 1768 , deserted the school, and became "anti-liberal." He had long been jealous of Quesnay's fondness for Du Pont."

1 See Schelle, p: 24, note. 
The Abbé Roubaud (I730-I789) at one time edited the Journal, and later the Gazette du Commerce, in a physiocratic spirit, until it was, at Turgot's expense, and at the commencement of his ministry, amalgamated with Baudeau's Nouvelles Éphémérides. His Récréations économiques, Amsterdam and Paris, I 770, attempted to refute the Dialogues of Galiani. ${ }^{1}$ $\mathrm{He}$ contributed to the Ephémérides, and was exiled from Paris by Maurepas on Turgot's fall in 1776 , like Du Pont and Baudeau. A jesting contemporary compared the sound of the names of the chief Physiocrats to that of a pack of hounds,-Mirabeau, Turgot, Baudeau, Roubaud!

If we add the agricultural writers, H. Patullo, Essai sur l'amelioration des Terres, I 759, and the Marquis de Turbilly, Mémoire sur les défrichements, i 760, to the authors mentioned in the next chapter, we have a tolerably complete list of Quesnay's disciples.

1 See post, p. I I 7 . 
THE meeting referred to in the last chapter (p. 49) at the Marquis of Mirabeau's house in 1774 , when he pronounced before the assembled economists a sort of funeral oration upon Quesnay, was only one of a long series, which had been suggested by Quesnay himself. From I 767 onwards the marquis had held a succession of Tuesday receptions. A number of economists came to dinner (some of them bringing or sending wine), and after dinner were read and discussed papers which were frequently published later in the Éphémérides. Mirabeau describes these Tuesdays in an interesting letter to Jean Jacques Rousseau, whom he vainly attempted to convert to physiocracy. ${ }^{1} \quad$ They were, he says, le foyer de la doctrine, were very largely attended, highly successful, and gave their votaries the name of économistes. Among those who atiended them at one time or another were the Princes of Weimar, the Maréchal de Broglie, the Duc de la Rochefoucauld, the Duc de Choiseul, the Maréchal de Belle-Isle, the Duc de Niver-

1 Levallois, J. J. Rousseau, ses amis et ses ennemis, Paris, 1865 , vol. ii. p. 385 . 
nois, Turgot, Malesherbes, Mme. de Pailly, a number of other ladies, and many distinguished foreigners and notabilities, attracted sometimes by mere curiosity rather than by scientific sympathy or economic interest. It was there, says Mirabeau, that Galitzin, the ambassador of Russia, came to tell Mercier de la Rivière that the Empress Catherine wished him to come to St. Petersburg to counsel her upon the art of government. On another occasion Forbonnais had been persuaded to come, and was introduced by Mirabeau to the Abbé Baudeau. "I want, like Cicero, to see," said the host, "if two augurs can look each other in the face without laughing."- "I am no augur," replied Forbonnais, "but monsieur (the Abbé) wears their robe." Baudeau whispered to Mirabeau that he was just about to publish a crushing attack upon Forbonnais in the Éphémérides. "Never mind," said the marquis confidentially, "we will gild the pill." Adam Smith can never have attended the Tuesdays, for he returned to England before they commenced. After the fall of Turgot (I 2 th May I 776), the marquis was "invited" by Government to suspend these assemblies, which thus had an existence of nine years. Some of Mirabeau's Tuesday addresses are extant among his manuscripts in the Archives Nationales at Paris. One of the papers still unpublished, on Political Curves by $\mathrm{Du}$ Pont, ${ }^{1}$

1 Knies, Carl Friedrichs von Baden brieflicher Verkehr mit Mirabeau und Du Pont, Heidelberg, I892, vol. ii. p. 289. 
seems to have been an early example of the diagrammatic(if not mathematical)treatment of economic questions; and the promise of Daniel Bernoulli to study these curves promised a serious development of the method, which was left, however, to other hands in later years. The meetings were a powerful engine for propagating and popularising the ideas of the school.

A still mightier force, however, was the periodical organ of the school, at first the Journal de l'Agriculture, as already stated, and later the Éphémérides. These contained a great number of interesting and valuable articles upon a variety of economic subjects by different hands. The best account of the Ephémérides is that written by Dr. Bauer for Mr. Palgrave's Dictionary of Political Economy. ${ }^{1}$ The Journal was edited by $\mathrm{Du}$ Pont, from September I 765 to November I 766 . Mirabeau says that the proprietors, impatient at the editor's unpunctuality and inexactitude, dismissed him from his post. ${ }^{2}$ Baudeau then put at the disposal of the Physiocrats his Ephémérides, founded December 1765. And in January 1767 it became their organ. Baudeau continued to edit it till May I768, when he was succeeded by Du Pont, who held the post till the review was discontinued (May I772; last number dated March I 772). It is usually stated that it was then suppressed by the comptroller-general, the Abbé

1 Vol. i. p. 743, s.v. Ephémérides, London, 1894.

2 The Journal existed from 175 I to 1783 . 
Terray. But Mirabeau throws further light upon this statement in a letter to his friend, the Marquis of Longo. The inveterate dilatoriness of $\mathrm{Du}$ Pont had, it appears, annoyed the booksellers, disgusted the subscribers, and run the journal into debt. "We profited," he says, "by the hailstorm upon journalists to make it come to an end at the fourth volume of I 772 with the decorum of persecution." There had been sixty-three volumes of this series. In 1774 Turgot, who had become minister, sanctioned its resuscitation, and Baudeau put out in December his Nouvelles Éphémérides Économiques ou Bibliothèque raisonnée de l'Histoire et de la Politique, ${ }^{1}$ of which eighteen further volumes appeared, twelve in 1775 , and six in 1776 . This was suppressed in 1776 , after the fall of Turgot. The Abbé Roubaud now (I775) began to edit the Journal de l'Agriculture, once more a physiocratic review (I775-I783). Baudeau attempted to revive his Nouvelles Éphémérides in I 788, but only a few numbers appeared before he went mad, and the publication ceased. Both the Éphémérides and the Nouvelles Éphémérides are extremely rare. Dr. Bauer states that the only known complete set of the latter is to be found in the library of the University of Giessen.

These journals of the Physiocrats, according to Dr. Bauer, are "the first example of journalism made subservient to social science, the richest source for

1 The Comte d'Albon assisted Baudeau to edit this series. 
the history of contemporary economic life, and the growth of modern ideas, not only in France but even in eastern Europe." They were written "with a distinct practical tendency, namely to struggle for free trade, free enterprise, and equal taxation; to combat the crushing burdens imposed by commercial restraints, industrial monopoly, arbitrary assessment, and lavish public expenditure ... and by inducing monarchs, statesmen, and landlords to introduce agricultural and financial reforms, to alleviate feudal burdens and commercial restraints, they benefited even the lower classes in Sweden, Denmark, Baden, Austria, and Tuscany. Thus they helped towards transplanting economic progress eastward both in thought and practice." I Among the contributors were Quesnay, Mirabeau, Du Pont, Mercier de la Rivière, Baudeau, Abeille, Le Trosne, Butré, Roubaud, St. - Péravy, Turgot, Morellet, Franklin, Fréville, Fourqueux, De Vauvilliers, the Duc de Saint-Mégrin, Bigot de Ste. Croix, the Abbé Loiseau, Rouxelin, De la Touane, Treillard, Belly, St. Maurice de St. Leu, and the Margrave of Baden. They had a wide and respectful circle of readers, of whom Voltaire was one.

One illustration must suffice to serve as an indication of the practical utility of these reviews. In I 767 a bad harvest having driven up the price of bread to a very serious extent, Baudeau published 
an article, Avis aux honnêtes gens qui veulent bien faire, in which he pointed out that a better system of grinding corn and baking would enable flour and bread to be sold at a cheaper rate. Mirabeau set up one of these economical flour-mills, and bakeries (fours économiques), at his property at Fleury, near Paris, and sold good bread at one-third less than the current price. $\mathrm{He}$ turned out nine hundred livres a day, and could, he says, have sold double as much if it could have been supplied. "The poor people," he writes; "fight who shall have my bread. It has become the fashion. The Duc de Choiseul sends a courier out twice a week for Fleury bread and so does Mme. du Deffand." ${ }^{H} \mathrm{He}$ intends to set up these mills everywhere, "send to the devil his feudal rights of banalité," and instead of compelling his people to bring their corn to his mills and pay their legal dues for grinding, will attract them voluntarily by the low price, which will upset the crying abuses of monopoly and regulation. The Prince of Rohan-Rochefort and other celebrities followed his example; and M. de Loménie tells us that the millers themselves adopted the improved form, which is in use in France to-day and produces more: flour than the old system from the same amount of corn. The interest of Mirabeau in this reform was so strong that the younger Mirabeau malignantly explains his father's preference for one of his daughters, the Marquise du Saillant, by saying 
that, among other things, her husband had feigned an enthusiasm for the moulins ćconomiques.

Another blow which the Physiocrats struck at monopolies to the enhancement of their own reputation is also associated with the name of Baudeau. The corporation of butchers had been compelled since I 743 to take loans of capital at high rates from a body of financiers, the farmers of the caisse de Poissy, ${ }^{1}$ who had advanced money to the Government. Baudeau denounced the iniquities of this arrangement, and was cited by the farmers before the tribunal of the Parliament in I 776. He successfully defended himself at two sittings against the famous advocate Gerbier, and was borne home in triumph by the victorious butchers through the streets of Paris amidst a concourse of his physiocratic brethren.

But it was not in Paris alone that these apostles of economic liberty obtained honour. Carl Friedrich, Margrave of Baden (I728-I8II), enrolled himself in their ranks. On the 22 nd of September 1769 he wrote to Mirabeau as follows: "I have a right as a man to claim your friendship" (a delicate allusion to L'Ami des Hommes), and he says that without being personally acquainted with Mirabeau he feels entitled to seek his counsel. God had brought him

1 See Ephémérides, r776, vol. i. ; Daire, vol. i. p. 649, note; and the authorities there cited. The butchers had to pay 6 per cent for a fortnight on their purchases of cattle, whether they borrowed the money or not. The sale of cattle at Paris was interdicted except at Sceaux and Poissy.-See Loménie, vol. ii. p. 249. Turgot abolished the caisse in 1776 . 
into the world to govern a country whose climate and soil held out the prospect of a good return to industry, when the necessary capital was applied to the land. But from time immemorial the land had, when handed down, been divided into as many portions as there were heirs. There were now no large owners and practically no tenant-farmers; and the produit net of the country was small and taxes were hard to collect. What advice would Mirabeau, as an economic expert, offer? Should there be a new law of succession to substitute for the compulsory partition of land a money payment by one heir to the others? And how could the produit net be made the basis of taxation in a simple and practical form? Answers to these questions would contribute to "spread the light of economic science by showing that it is applicable to all places and to all circumstances." Mirabeau deprecates new legislation. "You have not the right," he says, "to make such a law"; and he piquantly refers him upon the second point to his Théorie de l'Impôt, for the publication of which his own sovereign had cast him into prison. The correspondence thus begun ripened into friendship, and continued to the time of Mirabeau's death twenty years later. ${ }^{1}$ Personal visits were exchanged as well as books and letters, and Carl Friedrich consented to become the guardian of manuscripts which Mirabeau might leave behind him. The Margrave proposed free trade in corn to

1 See the work referred to at p. 79 note, supra. 
the German Diet, and even introduced the impott unique, 20 per cent of the produit net, in his own Duchy of Baden. The experiment was made in I 770 in the three villages of Dietlingen, Theningen, and Balingen - $a$ fact of which Adam Smith was probably unaware when he declared that "that system which represents the produce of land as the sole source of the revenue and wealth of every country has, so far as I know, never been adopted by any nation, and it at present exists only in the speculations of a few men of great learning and ingenuity in France. . . A system," he says, "which never has done, and probably never will do, any harm in any part of the world." 1 The experiment was abandoned at Theningen and Balingen in $\mathrm{r} 776$, but was maintained at Dietlingen till $\mathrm{r} 792 .^{2}$ The Margrave invited Du Pont to Carlsruhe, intending to put him at the head of his finances, but, not venturing actually to appoint a foreigner to this post, made him conseiller aulique, retained him at his side as an adviser, and made him tutor to his son. The Margrave himself wrote an abridgment of political economy, based mainly on Mirabeau's Les Économiques. It first appeared in the Éphémérides, and was separately printed and seen through the press by Du Pont in I 772 under the title Abrégé de l'Économie Politique. It forms a commendable précis of physiocracy.

I Wealth of Nations, bk. iv. ch. ix.

? See the account given by Emminghaus in Hildebrand's Jahrbücher, 1872, vol. ii. p. I. Also the Éphémérides, I77I, vols. iv. to vii. 
Another prince, Gustavus III., King of Sweden, who had made Mirabeau's acquaintance when travelling in France, honoured the Friend of Men, as well as himself, by the following letter (I 8th August I772, the day before his coup d'état): "Monsieur the Marquis de Mirabeau, the title which humanity has long since conferred upon you, is much above what kings can do for your glory. I have, however, been jealous to pay at least my share of the tribute which all nations owe to you. I have thought, moreover, that an institution created in honour of agriculture would be defective without the name of him who has taught sovereigns to recognise all its importance. Henceforth I consider myself more than ever authorised to beg of you the continuation of the useful lessons to which you have dedicated your labours and your rare knowledge; on my side I feel bound more than ever to profit by them. And I pray God, Monsieur le Marquis, to preserve you in His high and holy keeping.Gustave." This letter was accompanied by the grand cross of the Order of Wasa, just founded "in honour of agriculture." Du Pont was made a knight of the Order, and, when the Éphémérides were suppressed, Gustavus joined with his fellow-disciple the Margrave of Baden in commissioning $\mathrm{Du}$ Pont to send them a manuscript journal in which matters of economic interest should receive a large share. The king attempted to pursue, in his own politics, the 
liberal ideals of the school ; and it was at his request that Mercier de la Rivière wrote his work on public education, De l'instruction publique, I 775.

Mention has already been made of the advances of Catherine of Russia to Mercier de la Rivière, but these seem to have been little more than a womanly whim for the fashion of the moment, and to have had little practical result. When the philosopher arrived at her Court at Moscow she had an interview with him, which Thiébault reports as follows: ${ }^{1}$ "Sir," said the Czarina, "could you tell me the best way to govern a State well ?"- "There is only one, Madame," answered the pupil of Quesnay; "it is to be just, i.e. maintain order, and enforce the laws." "But on what basis should the laws of an empire repose?"- "On one alone, Madame, the nature of things and of men."- "Exactly, but when one wishes to give laws to a people, what rules indicate most surely the laws which suit it best?"- "To give or make laws, Madame, is a task which God has left to no one. Ah! what is man, to think himself capable of dictating laws to beings whom he knows not, or knows so imperfectly? And by what right would he impose laws upon beings whom God has not placed in his hands?"- "To what, then, do you reduce the science of government?"- "To study well, to recognise and manifest, the laws which God has so evidently engraven in the very organisation

1 Souvenirs de Berlin, vol. iii. pp. 167; 168, 2nd edition. 
of man, when $\mathrm{He}$ gave him existence. To seek to go beyond this would be a great misfortune and a destructive undertaking." - "Monsieur, I am very pleased to have heard you. I wish you good-day." She sent him home richly rewarded, and wrote to Voltaire: "He supposed that we walked on all fours, and very politely took the trouble to come to set us up on our hind legs."

A more serious interest in the Physiocrats was taken by Leopold II., Grand Duke of Tuscany, afterwards Emperor of Austria, to whom Mirabeau had dedicated Les Économiques, I 769-I772. He carried out some of their reforms in practice, ordered his ministers to consult with Mirabeau, and corresponded with Du Pont. Stanislas of Poland, Charles III. of Spain, the Emperor Joseph II., Ferdinand of Naples are also to be mentioned among their adherents. ${ }^{1} \quad \mathrm{~A}$ tribute to the fashionable craze for the "Agricultural System" was the ceremony performed by the Dauphin at Versailles, I 5 th June I 768 , when he publicly "held the plough"-a toy bedecked with ribbons. The Emperor Joseph more sturdily drove a peasant's plough in Moravia, I9th August I 769 . The Dauphin boasted of knowing L'Ami des Hommes by heart, and, but for Mirabeau's sturdy opposition, would have been willing to become the patron of the Éphémérides. Du Pont classes Carl Friedrich and Leopold (brother of Marie Antoinette)

1 See Knies, Brieficher Verkehr, vol. i. p. 74. 
among the followers of Quesnay; Joseph II. with Turgọt and Adam Smith; La Rivière and Baudeau as a separate branch. Du Pont wrote a heroic. drama upon Joseph II., which Turgot with difficulty persuaded him not to publish. Turgot's own chief economic work, his Réflexions sur la formation et la distribution des Richesses, November I776, I $2 \mathrm{mo}$, first appeared in the Ephémérides in I770, and the only cloud which for a moment shadowed his friendship with $\mathrm{Du}$ Pont was when the latter subjected these Reflexions to editorial amendment and "improvement," to bring them into harmony with the sacrosanct doctrines of Quesnay, when there appeared to be any departure from them. In his early writings in the Encyclopédie Turgot had expounded Gournay's ideas of freedom in industry and commerce (articles "Foires" and "Fondations"), and his noble efforts as intendant and as minister to carry these ideas into practice are permanently engraven in the history of France. $\mathrm{He}$ believed in the doctrines of the produit net and the impot unique, the central ideas of the school, but upon numerous points of detail he emphasised his differences and his independence, while he always speaks of the economists as an outsider, ${ }^{1}$ and is never tired of deploring their sectarian spirit and preaching the advantages of an open mind. It was

1 E.g. in a letter to Du Pont, "Les économistes sont trop confiants pour combattre un si adroit ferailleur," as Galiani. CEuvres de Turgot, vol. ii. p. 800. 
at Quesnay's rooms that he met Adam Smith in 1766. It was by Turgot's money, and sometimes by his pen, that Du Pont's Éphémérides were aided to keep afloat so long as they did; and he supported the expense of Baudeau's Nouvelles Éphémérides during his ministry. His youthful essay on Law's paper money, a letter to the Abbé de Cicé in I749, was written when he was but twenty-two years of age, and before the influence of the Physiocrats came into existence, but it shows already the powerful calibre of his mind. He was for many years immersed in administration; from I76I to 1774 was intendant of Limoges, and from 1774 to 1776 , after serving five weeks as Minister of Marine, was ComptrollerGeneral of Finance,- the most important minister of the kingdom. Nevertheless he found time in his active life to endow economic literature with valuable writings, as well as to enrich economic history by useful measures. We can refer only to those which directly concern us. In Limousin he applied himself to the Herculean labour of a complete survey or cadastre-a kind of Domesday - which should serve as a more rational basis for assessing the taille. $\mathrm{He}$ boldly abolished the corvée in his province, had the roads repaired by hired workmen, and threw the expense on the ratepayers. He proposed, but could not carry, a reform of the militia. And in numerous able memoirs he urged upon the ComptrollerGeneral, the Abbé Terray, free trade in corn, free 
trade in capital, and reforms of the taxes. When he found himself at the head of affairs he at once established the first, ${ }^{1}$ and took numerous steps to secure the last of these objects throughout the country, amended the octrois or municipal duties on articles of food and drink brought into the town, and in twenty-three towns abolished the droit d'aubaine, a special tax upon foreigners. He swept away the corvée everywhere, as well as the privileged jurandes or gilds, and battled at all points against monopolies and fiscal abuses. The opposition stirred up by this reforming zeal not only drove him from power, but within three months brought back again the corn laws, the corvée, and the jurandes. The jurandes were finally abolished in 1789 , and the corvées in I79I, while all internal duties or local tolls except the octroi were suppressed by the National Assembly in I790, on the ground that "they had made the different parts of the country foreign to one another." The preambles of Turgot's edicts, striking denunciations of old abuses and closely-reasoned pleas for their reform, had sunk in the minds of the people and prepared the way for their ultimate triumph.

Some of his writings have been. mentioned already. The letter on paper money, the articles in the Encyclopédie, the Éloge dc Goumay, the letter on Mines and Quarries--a plea for free mining even 
under the land of a neighbour provided his superficies be uninjured-and on la marque des fers, an argument against an apprehended tax on foreign iron, need not detain us. Of his seven letters to Terray on free trade in corn three were subsequently handed by Turgot to the king, and disappeared at the Revolution. Those which remain speak the language of the Physiocrats. "The revenues of the landowners," he says, "are the only source from which the State can derive its own revenue. In what form soever taxes be imposed or collected they are always, in the last result, paid by the proprietors of the land, either by increase of their expenses or diminution of their receipts." 1 And he expressly builds his policy upon Quesnay's estimates in the article "Grains." 2 In his Mémoire sur les prêts d'Argent he seized, as often, a particular occasion to lay down a statement of general principles. Defaulting debtors at Angoulême having denounced their creditors for infractions of the usury laws the whole fabric of credit was rudely shaken. Adam Smith need not have waited for Bentham to convert him from Quesnay's opinion in favour of usury laws if he had carefully studied Turgot's admirable argument against them. The canonist and the jurist are alike refuted. St. Thomas Aquinas and appeals to Scripture are dealt with on one side, the eminent Pothier

1 Quvres, I 808 , vol. vi. p. I 58.

2 See pp. 29-35, supra. 
on the other. Turgot approximates somewhat closely to the position which Adam Smith subsequently assumed by admitting that loans to prodigal sons are injurious to society. But he logically urges that they should be punished on that ground alone, and not because they are loans. ${ }^{1} \quad$ The Usury Laws were abolished in France at the Revolution, long before they disappeared from the Statute Book in England.

The Reflexions sur la formation ct la distribution des Richesses were written in 1766 for two Chinese students who were returning from France to their own country. They appeared in the Éphémérides in 1770 , and were published in book form in 1776 . Cossa considers that "this work states in a clear and taking form the common doctrines of the Physiocrats, but it also marks a step forward in the history of our science, since Turgot achieved in it a complete separation of economics from jurisprudence. It therefore deserves to be entered in red-letter, as the first scientific treatise on social economics." 2 This judgment can hardly stand, for Cantillon at least preceded Turgot, and, as comparison would abundantly show, influenced this work very considerably. Turgot divides his book into a hundred short sections or paragraphs. Commerce, he says, arises from (I) the unequal distribution of land; (2) the diversity of the soil

2 Introcluction to the Study of Political Economy, 1893, p. 264. 
in fitness for production; (3) the multiplicity of human needs, and (4) the advantages of the division of labour, which he illustrates by examples. The agricultural labourer is pre-eminent over the artisan, not in honour or dignity but in physical necessity, for he might do without them but they cannot do without him. In fact, what his labour produces from the soil is the only Wages Fund (l'unique fonds des salaires), and the commodities which he buys are the exact equivalent of the produce which he gives in exchange. Competition forces artisans' wages down to subsistence level (the doctrine of Necessary Wages). But the agricultural labourer produces a surplus over and above this, for Nature does not higgle with him for a subsistence-wage, and he is thus the only producer of wealth. The extractive classes, then, are productive, the artisan classes salaried ('une productive, l'autre stipendiée). As society progresses and lands are all taken up, the owner becomes distinct from the labourer, the newcomers may as well earn wages on the land as in manufactures. The product is now divided into two parts - the wages of labourers and the surplus which goes to the landlord as his revenue. The landlord becomes available for social needs like war and justice, either by personal service or by deputies whom he pays. He may therefore be assigned to a third class, an available reserve (classe disponible). The evolution of labour on the land is traced from 
(I) labourers to (2) slaves, (3) serfs, (4) metayers, (5) farmers̀. He proceeds to examine the mechanism of exchange, and describes the stage of barter and the rise and nature of money in terms reminiscent of Cantillon, and suggestive of comparison with Adam Smith. The accumulation and social utility of Capital is next sketched, and its functions in aid of production are described with an argument that interest for the use of capital is as legitimate and should be as free as the sum paid for the use of land or any other object of commerce, and depends, in either case, upon supply and demand. The annual net produce of the land of a country capitalised, plus the movable wealth in the country, gives the sum of the national riches,-excluding loans, for they would otherwise count twice over. The capitalist, who lends at interest, does not form part of the classe disponible, and his income is not available for the State, for it is not a produit net, but the result of a buying and selling like the profit of other merchants. It should no more be taxed than the manure which fertilises the land. "C'est toujours la terre qui est la première et l'unique source de toute richesse." "Il n'y a de revenu que le produit net des terres"-a frankly physiocratic conclusion. ${ }^{1}$ Yet the Phýsiocrats hardly claimed Turgot for their own, and even in the height of his prosperity Mirabeau's

1 The book was translated into German by. Mauvillon, who was converted by the task into an ardent Physiocrat. See p. Ioo, post. 
letters refer to him with a mistrust not unmingled with disdain - a feeling partly due, no doubt, to Turgot's somewhat haughty independence, his lack of political tact, his reservations upon monarchy, his friendship with Voltaire, and his alleged scepticism. Yet, upon the last point, it is Mirabeau himself who recounts Turgot's phrase, "Je ne suis point encyclopédiste car je crois en Dieu. Je ne suis point économiste car je ne voudrais pas de roi." 1

Other writers who were, like Turgot (himself known as an abbé-the Abbé de Laulne-in his Sorbonne days), in virtual but not unreserved accord with the Physiocrats, were the Abbé Morellet and the Abbé de Condillac. Morellet (I727-1819), a follower of Gournay, and a college friend of Turgot, was called by Voltaire the Abbé Mord-les from his polemical sarcasms. He wrote Réflexions sur les avantages de la libre fabrication et de l'usage des toiles peintes en France, Geneva, I 758 , supporting Gournay against Forbonnais, and a pamphlet addressed to Malesherbes, Fragment d'une lettre sur la police des grains, Brussels and Paris, I764. He published in I 769 a memoir against the monopoly of the East India Company, and carried on a warfare against Necker as well on this subject as on Free Trade in corn. Of interest to economists are also his Réfutation of Galiani, London, I770, his Prospectus d'un nouveau Dictionnaire du Commerce followed by a

1 Loménie, vol. ii. p. 4 I 6. 
bibliography of economics, Paris, I769, and his Mémoires sur le XVIII siècle et sur la révolution, posthumously published in $182 \mathrm{I}$. The last of these contains oft-quoted references to his acquaintance with Quesnay, Turgot, and Adam Smith. Lavergne, in his Économistes français du XVIII siecle, has devoted an essay to Morellet, almost the latest surviving friend of the physiocratic leaders. He disclaims being a member of the inner circle, says he had never attended their meetings or understood the Tableau Oeconomique, and accepted their doctrines only with some modifications.

Condillac (I 7 I 4-1 780), better known as a philosopher, is remarkable by his treatise, $D u$ commerce et du Gouvernement considérés relativement l'un à l'autre, I776, in which he follows the doctrine of Quesnay so far as to regard the land as the sole source of wealth, but refuses to regard industry as "unproductive." Jevons, while praising the work as "original and profound," points out its obligations to Cantillon. Mr. M'Leod has covered it, in his Dictionary of Political Economy, with exaggerated praise, while J. B. Say stigmatises it with undeserved contempt. The orthodox Le Trosne engaged in a discussion with Condillac upon his dissent from the school, but was unable to convince him.

Condorcet (I 743-I 794), likewise a philosopher, and a friend and biographer of Turgot, is also to be mentioned among the allies of the Physiocrats. He 
pleaded for freedom in the Encyclopédie (arts. "Monopole" and "Monopoleur"), and in his Lettres sur le commerce des grains, Paris, I775; Réflexions sur le commerce des blés, Londres, I776; Réflexions sur l'esclavage, Neufchatel, I $78 \mathrm{I}$; and wrote to Necker a Lettre d'un laboureur de Picardie à $M . N$. . ., auteur prohibitif à Paris, Paris, I 775.

It is hardly possible to do more than mention the principal disciples of the Physiocrats in foreign lands. The more important are-in Germany, besides Carl Friedrich of Baden, already referred to, Schlettwein, Fr. Karl von Moser, Mauvillon, Schmalz and Krug; in Switzerland, Iselin; in Italy, Longo ; and in Russia, Galitzin. Mention of other lesser lights will be found in the Histories of Political Economy of Roscher, Kautz, ${ }^{1}$ and Cossa. Schlettwein ( I 73 II 802), Professor at the University of Giessen, is regarded by Professor Oncken as the chief of the German physiocratic school. Officially charged with the administration of the domains of the Margrave of Baden, it fell to him to conduct the experiment of the impott unique in $1770,{ }^{2}$ and his faith remained firm to the last. F. K. von Moser (I 723-1 798) - not to be confounded with the more famous

1 Kautz, referring to J. J. Rousseau's article Economie politique in the Encyclopedie, strangely describes him as a follower of the Physiocrats. The truth is that this article was written before their "school" was founded, and Mirabeau's efforts in later years to convert Rousseau, or even to capture his attention to their doctrines, proved fruitless.

${ }^{2}$ See p. 86, supra. 
Justus Möser, the cameralist, nor his own father Johann Jakob von Moser ${ }^{1}$ - was an adherent of the Ami des Hommes. Mauvillon (I 743-I 794) became a Physiocrat through translating into German the Reffexions of Turgot, and spread the doctrine in Germany by his Physiokratische Briefe an den Herrn Professor Dohm, Brunswick, I 780 . He also wrote an essay on "Public and Private Luxury," how to check it according to the principles of the French Physiocrats, in his Sammlung von Aufsatzen, etc., I776-I777. Roscher considers him the ablest of the German Physiocrats, and Cossa describes him as a profounder thinker than Schlettwein, views which Professor Oncken does not share. Other adherents are Fürstenau, Versuch einer Apologie des physiokratischen Systems, I779, and Springer, UUber das physiokratische System, I780. Schmalz (I760I 83I), Professor of Law at Berlin, examines the various systems of Political Economy, and (as late as I 808) gives the palm to that of Quesnay. The same year Krug (I770-I 843) expressed his concurrence in the view that it is the land upon which all taxes ultimately fall, and is therefore the only proper object of taxation." The adherents of the Physiocrats are thus brought down to the memory of those still alive.

Isaak. Iselin (I 728-1 782), Secretary to the State

1 See post, p. 122.

2 Abriss der Staats-Oekonomie, Berlin, I808. 
Council at Basle, seems to have been introduced to a study of the Physiocrats by Schlettwein, before he wrote his Versuch iiber die gesellige Ordnung, I 772. The Éphémérides, he says, made Quesnay appear to him what Newton is to a mathematician. He recast his Traïme eines Menschenfreundes (Dreams of a Friend of Men) in I 776, abandoning the views of his earlier edition twenty-one years before, and started a German Ephémérides, Ephemeriden der Menschheit, the same year, with the co-operation of the chief German writers on Political Economy. ${ }^{1}$

The Marquis de Longo, Professor of Political Economy at Milan, has already been referred to ${ }^{2}$ as a friend and assistant of Mirabeau, with whom he exchanged a lengthy correspondence, upon which Loménie has drawn with advantage. The Prince de Galitzin ${ }^{3}$ (I 730-1803), it will be remembered, was the Russian ambassador at Paris, who frequented the Tuesdays, and persuaded Catherine to send for Mercier de la Rivière. Many years later he published at Brunswick a work De l'esprit des économistes, ou les économistes justifiés d'avoir posé par leurs principes les bases de la revolution française, 2 vols. 8vo, I796, in which he exculpates the Physiocrats from responsibility for the more violent principles of the Revolution.

1 See A. von Miaskowski, Isaak Iselin, Basle, J.875.

2 Page 58, supra. 3 Pages 69, 79. 
François Louis Véron-Duverger de ForbonNAIS (I 722-I 800) was one of the chief contemporary opponents of the Physiocrats in France. He wrote the articles "Change," "Colonies," "Commerce," etc., for the Encyclopédie, and translated or adapted The British Merchant (Le négociant anglois, I 753) from the English, and Ustaritz's Theory and Practice of Maritime Trade from the Spanish, I753; but he is best known by his great works on finance, Considérations sur les finances d'Espagne relativement à celles de France, I753-55, and especially by his Recherches et considérations sur les finances de France depuis 1595 jusqu'en I721, I 758,-a standard critical and historical account. He concerns us chiefly by the general tenour of his views (for his was the highest economic reputation opposed to that of the Physiocrats), and by the writings which he directed expressly against them. His Principes et observations économiques (Amsterdam, 2 vols., I 767), with the motto est inodus in rebus, is a close and weighty 
criticism of the Tableau Oeconomique, and the articles "Fermiers" and "Grains." The Physiocrats replied in the Éphémérides of the same year. They recognise his ability and intelligence, but regret that he dwells in the thick darkness of Colbertism. $\mathrm{He}$ is, in reality, a very moderate and level-headed writer of a practical turn. He refuses to admit that trade and industry are sterile. Without human agency the land itself is doomed to absolute or relative sterility, and the energy of labour is as much a factor in the production of wealth as the material upon which that energy is expended. $\mathrm{He}$ objected to free trade and the impott unique. He opposed privileges and exemptions from taxation, desired moderate import duties, a reduction in the expenses of the royal household, and recommended graduated and progressive taxes upon articles of luxury as well as upon the land, which could not, he maintained, be fairly saddled with the whole burden of taxation. $\mathrm{He}$ lent himself to attack by maintaining the Mercantilist position that the State should endeavour to obtain a favourable balance of foreign trade, but shows to more advantage in controverting the dictum of Quesnay that "dearness and abundance constitute opulence," though he does not realise the full force of the paradox. While the Physiocrats stood for laissez-faire, he upheld State regulation; and his official position as Inspector-General of Mints, and as a confidant of the Duc de Choiseul and Silhouette, Comptroller-General 
of Finance, contributed to cause the Physiocrats to regard him as their most redoubtable adversary. Towards the close of his life he wrote in Du Pont's journal L'Historien (I795), supporting the editor's efforts in the Conseil des anciens. But this reconciliation did not extend to his economic views. His Eléments du Commerce, I 754, was reprinted in I 796, with the addition of portions of the Principes, in which some of his strictures upon the Physiocrats were repeated. He pays tribute to the originality and substantial value of their speculations, while protesting against the extravagant length to which they were carried.

Widely different from the matter-of-fact Forbonnais, whose bent of mind is comparable to that of the German cameralists, was the Utopian Abbe de Mably (I 709-I 785), whose criticisms of Mercier de la Rivière are, however, by no means to be despised. Fastening upon the earlier political and philosophical chapters of the Ordre naturel et cssentiel des Sociétés politiques, which Daire has omitted from his Physiocrates, and passing by the later, more strictly economic, chapters which Daire has printed, he published in I 768 his Doutes proposés aux Philosophes économistes sur l'Ordre naturel et essentiel des Sociétés politiqucs in the form of ten letters addressed "to the author of the Ephémérides du Citoyen." $\mathrm{He}$ begins as follows: "Sir, I have long been, like you, the disciple of the celebrated philosophers whom you 
call your masters. How many truths do we not owe to them on the nature of taxes, on the means of making agriculture and 'trade prosper! After' having exhausted these matters, one has learned with pleasure that our masters meditated still greater discoveries, and were going to deal with the first principles of society. . . . These hopes, I will admit, sir, were nevertheless accompanied by some misgivings. It was seen that our philosophers had a kind of contempt for the peoples whom we were most accustomed to respect, and exhibited a predilection for the government of China . . . ; but in the fear of blaspheming against unknown truths one waited in silence for the Oracle to speak with less of mystery." Now that the Oracle has spoken, the reader is unconvinced, and seeks further explanations.

His first letter may be thus summarised. How can property in one's person, in movable things, and in land be "three sorts of property inseparably united"? The first may exist (as in communism) without the second, and (witness the Iroquois, the Hurons, and the Spartans of old) without the third. Landed property is an arbitrary human institution. You will say that property is a stimulus to labour. But has it not introduced idleness into the world? And are avarice and gratification alone capable of stirring the human heart, or might not the love of distinction, honour, and glory produce greater effects than property itself? The Ordre naturel seems, 
after all, to be contrary to nature. On landed property follow unequal fortunes and all their attendant vices of wealth and poverty, the rich despising the poor, injustice, tyranny, and oppression. Nature meant us to be equal, gave us the same needs, and united us by social qualities which would have made us happy, but wealth and poverty engendered brutality and ferocity. It would be vain to seek to go back to nature, for property creates its own supporters, and an attempt to abolish it would provoke greater disorders than those we fly from. But why not seek palliatives? Why narrow ourselves to extend the culture of the fruits of the earth and not the culture of the social qualities? If avarice, ambition, and vanity were abolished, men would be happier even with less wealth. Property is unnatural and anti-social. True, nature may have given one man greater strength than another, but this is no reason for greater individual wealth, unless force and ruse are to be glorified. Modern philosophers present the abuses of our passions as laws of nature. Admitting that man's physical needs contributed to the establishment of society, surely moral causes have co-operated. Man is not a physical machine, but an inseparable blend of the physical and the moral. No doubt it is physically impossible to live without subsistence, but so it is to live in society without social qualities, and these have contributed the greater share to the establish- 
ment of society. Agriculture was designed for society, and not society for agriculture. If we, like animals, concerned ourselves only with subsistence, we should, like them, be incapable of society. Justice, prudence, courage, are as necessary as the fruits of the earth. Without them we should be devastated by foreigners. The cultivation of men and the social virtues is the basis of social happiness: let our fields come after.

The communistic feeling which appears in this first letter becomes stronger and more evident as he proceeds, but his remarks on communism may be omitted without weakening the rest of his criticism, which proceeds as follows: Why are the rulers and magistrates of La Rivière's ideal society co-proprietors of the produit net? Confidence, esteem, and respect should be their sufficient reward. Corruption follows upon money-payments to them and to soldiers. It is unreasonable to expect a labourer to be satisfied that the best possible state of society is one which leaves him in a pitiful condition, while large landowners live in luxury. Equality alone produces contentment. The pretended union of society is a fiction. Why should I be satisfied to play the miserable rôle of poverty, while others, I know not why, have the fat part of the rich? Moreover, the Économistes are strangely inconsistent. Sometimes they regard man as a browsing animal, concerned only with his nourishment, the maximum production 
of the fruits of the earth his social ideal. When they deal with him as an intelligent being, he ceases to be a voracious animal and becomes an angel, docile to the manifestations of reason (évidence). Evidence appears and passions are respectfully silent. Would to Heaven it were true! But passions govern the world; and men reck not of évidence, which changes from time to time like other fashions, but are ruled by opinion. Moral and political truths are not like geometrical propositions. Euclid is unassailable, but his terms are simple and clear, while our problems have a hundred different facets, and prejudice and private interest pervert the mind. Do not be too confident in the victory of reason over passion. One error gives way to another, and new passions arise when the old are gone.

Passing next to the constitution of ideal society, he asks: If évidence is so convincing, why trouble about the forms of government? Every government would be equally good. The author would need only to tell us of the necessary public schools, and the doctrinal works which the philosophers should hasten to compose. ${ }^{1}$ Certainly laws should be just, but no precept was ever better known and more neglected : and the injustice of laws is directly proportioned to the inequality of fortunes. Your magistrates are to be perfectly wise, but such men

1 Mercier de la Rivière responded to this challenge by his book $D e$ l'instruction publique, 1775. See supra, p. 88. 
are rare out of China, where the Economistes think nature has been pleased to mould a nation of sages. The magistrates are a check upon the imperfections of the Despot, but why should not the magistrates be imperfect too? It would have been simpler to make the Despot infallible at once; and if he differ from the magistrates, will not confusion and arbitrary despotism arise? The crown is to be hereditary. By what secret do you ensure a succession of enlightened Despots in lineal descent? You say that in the last resort the nation itself is the judge, but its organised coercive power is centred in the Despot, who thus by a vicious circle is the check upon himself. The rhapsodies of some writers over the agriculture of China have bewitched the author to such a point that he wished to copy their government.

He now descends into a detailed examination of the reports of missionaries and others upon the history and condition of China, which he finds upon many points to be contrary to reason and experience, and he concludes that the writers have been misled or mistaken. Even if it were not so, a horde of inhabitants, slavishly obedient to custom, free from the fear of foreign wars, and surrounded by no redoubtable enemies, but too timorous and effeminate to make head even against the Tartars, would be no model for the progressive people of France, with whom martial qualities are a condition of national existence. The Emperor's wants are satiated 
by immense wealth, and he has no need to increase the contributions of his people. But what parallel does this afford for France ? ${ }^{1}$

$\mathrm{He}$ criticises vigorously La Rivière's opinions upon the necessity of separating the legislative and the executive power, and of avoiding a democratic or even aristocratic assembly of lawgivers. $\mathrm{He}$ points to the example of England, and pleads that until humanity is infallible society must decide upon the probable advantages of contemplated changes by a majority of votes. Morals deserve the principal attention in politics; good or bad, they decide the fate of States.

In conclusion he says: "If I have thought that I find nothing but errors and a sophisticated and dangerous doctrine in the first two parts of the Ordre naturel et essentiel des Sociétés, I will say with the same sincerity that the third part of that work presents a great number of important truths on taxation, agriculture, and commerce. I might have wished to discuss a certain thirty-fifth chapter, ${ }^{2}$ where I think I see many errors mixed with a few truths, but this would need a work which I have not the courage to undertake. I await your explana-

1 It is curious that Mably does not see here, and especially in his later writings, that he exposed himself to the same line of criticism with regard to the different circumstances of different countries, in his unbounded praise of Sparta. Mutato nomine de te fabula narratur. What China was to the Physiocrats, Sparta was to Mably. Moreover, Spartan society was based on slavery.

2 This chapter deals with international relations. See supra, p. 73. 
tions with the greatest impatience, and though you may perhaps regard me as a spirit rebellious to évidence, whose conversion cannot be hoped for, I pray you not to refuse them to me." This last letter is dated 27th October I767. The Ephémérides replied in a series of seven articles ( $1768-69$ ), which profess to clear up the doubts expressed.

These wordy disputations of secluded philosophers are not without great practical importance. It was an age of ideas, -an "age of paper" as Carlyle has epigrammatically declared-and there were men of action eager to receive ideas and to put them into practice. The important position of Mably in the history of communism does not fall within our subject. ${ }^{1}$ But it is necessary to add that the Poles begged Mably to frame their laws, and that he went to Poland for this purpose and published in I77I a work Du gouvernement de la Pologne. Still more important is the fact that the American Congress desired him to draw up a constitution, which led to his Observations sur le gouvernement et les lois des États-Unis d'Amerique, I 784 .

The title of Mably's book was very likely suggested by the philosophic doubts of Descartes. The Doutes sur la théorie de l'impôt, I76 I, a reply to Mirabeau, is the anonymous work of Le Pessellier. Most of the important writings of the Physiocrats,

1 It is discussed by A. Sudre, Histoire du Communisme, I 849 . 
called forth a "refutation" in some form or another. Messance wrote to disprove the thesis of L'Ami des Hommes that the population of France was decreasing. Rivière (not Le Mercier de la Rivière) published in I76I L'Ami de la Paix, ou réponse à la théorie de l'impôt du Marquis de Mirabeau. Of many other works directed against the impôt unique upon land, it may suffice to mention Guiraudet's Erreurs des Économistes sur l'impôt in I 790 ; the Marquis de Casaux's Absurdité de l'impôt territorial, I 790 ; Considérations sur l'effet de l'impôt, I 794 ; and J. Tifaut de la Noue's Réflexions philosophiques sur l'impôt, I 774.

The Ordre naturel was not to escape with the onslaught of Mably. Voltaire (I694-I774), provoked by the injudicious, exaggerated praise of Galitzin ${ }^{1}$ and others, and irritated as well by the arrogant and sectarian spirit as by the conclusions of the author, took up his pen "in a moment of humour," as his editor tells us, and perpetrated a witty attack upon the book (which he had probably never read) and upon the Economistes as a whole. L'homme aux quarante écus, I 767, though flippant and shallow, is a very smart satire charged with Gallic humour and vivacity which might have effectually laughed down a less earnest and strenuous body of men. It makes fun of statisticians, theoretical financiers, physiocrats, geologists, doctors, biologists, ecclesiastics, and others; but the Physiocrats are in 
the forefront. An extract will give the best idea of the form and nature of the attack:-

"I am happy to make known to the universe that I have a piece of land which would be worth 40 crowns $^{1}$ a year net but for the taxes.

"There appeared several edicts of a few persons who, finding themselves at leisure, govern the State from their fireside. The preamble of these edicts ran that the legislative and executive power is born by divine right co-proprietor of my land, and that I owe it at least the half of what I eat. The enormity of the maw of the legislative and executive power made me cross myself earnestly. What if this power, which presides over the essential order of societies, were to have all my land, which would be still more divine than ever!

"Monsieur the comptroller-general knows that I only used to pay $\mathrm{I} 2$ livres in all, that it was a very heavyburden for me, and that I should havesuccumbed if God had not given me the genius to make wicker baskets, which helped me to support my poverty. How then can I all at once give the king 20 crowns?

"The new ministers said also in their preambles that only land ought to be taxed, because everything comes from the land, even the rain, and that consequently there are only the fruits of the earth which owe taxes.

1 The $e c u$ of 3 livres : 40 écus $=120$ livres was the sum which Mercier de la Rivière considered sufficient for the existence of each citizen in a physiocratic society. 
"One of their bailiffs came to me in the last war; he demanded of me for my quota three bushels of corn and a sack of beans, the whole worth twenty crowns, to maintain the war which they were carrying on - the reason of which I have never known, having heard merely that in this war my country had nothing to gain and much to lose. As I had then neither corn nor beans nor money, the legislative and executive power had me dragged off to gaol and they carried on the war as best they could.

"Coming out of my prison with nothing but my skin on my bones, I met a plump and ruddy man in a carriage with six horses; he had six man-servants, and gave each of them in wages the double of my income. His steward, as ruddy as he, had a salary of 2000 francs, and robbed him of 20,000 a year. His mistress cost him 40,000 crowns in six months: I had known him formerly in the time when he was less rich than I. He told me, to cheer me up, that he had 400,000 livres a year. 'Then you pay 200,000 to the State,' said I to him, 'to carry on the advantageous war which we have; for I, who have only my I 20 livres, have to pay half of them?'

" 'I ?' said he, 'I contribute to the needs of the State? You are poking fun, my friend; I have succeeded an uncle who had gained eight millions at Cadiz and Surat; I have not an inch of land : all 
my property is in securities; I owe the State nothing; it is for you who are a landed gentleman to give half of your subsistence. Do you not see that if the Minister of Finance required of me some assistance for the country he would be a misguided idiot; for everything comes from the land; money and notes are only tokens of exchange; instead of staking at cards a hundred bushels ' of wheat, a hundred oxen, a thousand sheep, and two hundred sacks of oats, I wager piles of gold which represent these disgusting commodities. If, after putting the impôt unique on these commodities, they were still to ask me for money, do you not understand that they would be getting it twice over? My uncle sold at Cadiz two millions of your corn and two millions of cloth made with your wool; he gained over roo per cent in these two affairs. You see clearly that this profit was made upon land already taxed; what my uncle bought of you for ten sous he sold for over fifty francs in Mexico; and, all expenses paid, he came back with eight millions.

"You perceive of course that it would be a horrible injustice to require of him again a few oboles over the ten sous he gave you. If twenty nephews like me, whose uncles had gained, in the good time, eight millions at Mexico, Buenos Ayres, Lima, Surat, or Pondicherry, only lent the State 200,000 francs apiece in the urgent need of the country, it would 
produce four millions. How horrible! Pay, my friend, you who enjoy in peace a clear and net income of forty crowns, serve well your country, and come now and then to dine with my servants.'

"This plausible speech made me think a good deal, but did not console me much." ${ }^{1}$

Voltaire became better acquainted with the Physiocrats' and their work in later years and praised them very highly. His admiration of Turgot as man, philosopher, and minister was unbounded. ${ }^{2} \mathrm{He}$ wrote to $\mathrm{Du}$ Pont in 1774 : "J'ose féliciter la France que $M$. Turgot soit ministre et qu'il ait un homme tel que vous près de lui." And in his Fragments sur l'histoire he says: "I have read the Éphémérides du Citoyen, a work worthy of its title. 'This journal, and the good articles upon agriculture in the Encyclopédie, are enough, in my opinion, for the instruction and happiness of a whole nation. ... I have written nothing upon agriculture because I should never have been able to do anything better than the Ephémérides." Like Mably, therefore, Voltaire was a partial adherent as well as, in some respects, a formidable opponent of the Physiocrats. The elder Mirabeau hated him

1 Condorcet defended the Physiocrats against this sally in his edition of Voltaire. See also A. Batbie, L'homme aux quarante écus et, les Physiocrates.

2 See L'epitre à un homme, written on Turgot's fall, his letters and memoirs addressed to Turgot, and especially his Diatribe a l'auteur des Éphémérides (Baudeau), Geneva and Paris, I775, in which he describes Turgot as better informed than Sully, with as large views as Colbert, and with more true philosophy in his mind than either one or the other. 
heartily. In one terrible sentence he accuses him of breathing a leper on the human race, ${ }^{1}$ and his indignation on reading $L \dot{a}$ Pucelle was so great that he. "flung the book physically into the fire."

Hardly less self-restrained than Voltaire himself was the Abbé Galiani (1728-1787), a Neapolitan envoy at the Court of Paris, and one of the wittiest writers who ever dealt with economic questions. The little Abbé (he was only $4 \frac{1}{2}$ feet in stature) was the pet of the Paris salons; and there must have been many who found the Physiocrats too dry and dull to be read, who eagerly devoured the amusing writings of Voltaire and Galiani. In his Dialogues surle commerce des blês, Londres, I770, translated from the Italian by Diderot, Galiani took up a position nearly approaching that of the extreme wing of the modern historical economists. Abstract principles are no safe guide of commercial policy. Corn laws which are good in one time or place may be bad in another. The best policy for France is not necessarily the one which has proved best in England, Holland, or Italy, or even in the France of Colbert's time, which was a different France from that of to-day. The statesman who admired Colbert should not imitate him, but ask himself, "What would Colbert do if he were here now?" Land cannot be the sole source of wealth, because Geneva, Frankfort, Lucca, and other free cities are rich, with little land and that little infertile.

1 Il a souflé la lepre sur le genre hamain. Loménie, vol. ii. p."266. 
The man in the comedy whose mania was to turn the whole of his country into seaports was hardly more foolish than the Physiocrats whose proposed free trade in corn might do very well for a country like Holland, which has to get her corn from abroad. The best of all systems is to have no system. Manufacture is a kind of production, for it adds to the raw material (elle ajoute à la matière première). Commerce also adds freight to raw material, and is thus a source of subsistence to many. Not only corn laws are desirable in some circumstances, but even bread laws and State granaries. But in no case can England be a model for France. England is the most complicated and artistically-contrived political machine the world has ever seen. She is at once agricultural, manufacturing, martial, commercial, and is really all seaport. Everything is peculiar in England-character, manners, soil, climate, products, etc. She takes the treasures of Bengal to stake them at Newmarket, and exercises her troops (sailors) when carrying on her foreign trade. In fine the book is a clever dissertation upon its motto, a line of Horace :

In vitium ducit culpae fuga, si caret arte.

"You are the only sensible man I know," says the Marquis de Roquemaure, one of his interlocutors, to the Chevalier Zanobi (Galiani), "who is against the export of corn."-" I am against nothing," is the repartee, "but the export of common sense." Galiani complained in 
later years that no one had understood the purport of his book, and that what he had meant his readers to infer was that free export was impossible under a despot, and therefore impossible in France. This is in keeping with his definition of eloquence as "the art of saying everything without going to the Bastille" : but the reader, even now, will find it difficult to read into the book the intention suggested. The Dialogues met with great success. Voltaire said Plato and Molière seemed to have combined to write it. Turgot was much struck by its elegance and gay wisdom, though he noted its inconsistencies. The Éphémérides rushed into the lists. In the number dated December I 769, but published later, Du Pont replied to Gáliani. The next month, and more effectually, Baudeau essayed the task. Roubaud wrote a refutation in the Gazette du Commerce. In I 770 appeared Morellet's Refutation (see p. 97, supra); and Mercier de la Rivière brought out a pamphlet entitled L'Intérêt gênéral de l'Etat, ou la liberté du commerce des blês, etc., avec la réfutation d'un nouveau système publié par l'Abbé Galiani, etc., Amsterdam and Paris, I 770, to which the abbé answered by La Bagarre, still unpublished. Galiani, now returned to Italy, kept up a correspondence with Paris in which he overwhelmed the Physiocrats with persiflage for their ennui narcotique, and mockingly proposed for himself a statue on which a Latin inscription was to declare that he had "wiped out the economists, who were sending the nation to 
sleep "- economistis deletis qui rempublicam obdormiebant. ${ }^{1}$ Grimm and Bachaumont followed his cue in their literary correspondence, and reviled the Physiocrats for their dulness and their arrogance.

Graslin (I 727-I 790), a receiver-general of taxes at Nantes, was a serious economical writer, who stood up fairly and squarely against the doctrines of the impôt unique and the territorial source of wealth, with an amount of ability unsurpassed by any of their critics. When Turgot offered a prize for an essay on the incidence of indirect taxation, Graslin had the courage to compete with an anti-physiocratic essay which drew forth a reply from Turgot. $^{2}$ The prize was awarded to Saint-Péravy, ${ }^{3}$ but Graslin's essay was given honourable mention. In 1767 appeared his Essai Analytique sur la Richesse et sur l'Impott, Londres, arguing that the produce of the land is wealth, even though it be equal merely to the cost of production,- - a proposition which the Physiocrats would not have disputed,- and that industry applied to raw material is as much wealth as the raw material itself. So far from all taxes falling ultimately on land, he contended that taxes levied on the land might ultimately be shifted on to consumers.

1 See for a recent study of Galiani and the Physiocrats, Frank Blei in the Berner Beiträge zur Geschichte der Nationalökonomie, No. 6. Berne, 1895 .

2 Euvres, Paris, 1844, p. 439. Du Pont also replied in his Lettre à Saint-Péravy, Ephémérides, 1768, tome ii.

3 See p. 76, supra. 
His Correspondance contradictoire with Baudeau, London, 1779 , well repays perusal as a capable discussion on both sides of the doctrines of the school.

Necker (1732-1804), the opponent of Turgot in action as well as in theory, ranged himself with Forbonnais on the side of State-regulation,- - a fact which did not prevent him from making a fortune by speculating in corn during the brief triumph of free trade after I764. His Eloge of Colbert, 1773, and his works Sur la Legislation et le commerce des Grains, I 775, and De l'administration des finances de la France, 1784, lose no opportunity of emphasising his dissent from the doctrines of Laissez-faire. and the Tableau Oeconomique. His declamatory. appeals to the rights of humanity and attacks upon landed property, though probably incited by an ambitious desire to secure political popularity, bring him into close harmony with State-socialists, who, like himself, desired a large intervention of the Government; and the Physiocrats had always to reckon with him as a determined adversary. His Mémoire au roi on municipal government plagiarised Mirabeau's Mémoire on the subject (see p. 20, supra).

The most sarcastic of all the writers against Quesnay and his school was the crack-brained and contentious Linguet ( I 736-I 794), a lawyer of much ability. In an attack upon Montesquieu, he stated that society lives by the destruction of liberty, as carnivorous beasts live on their prey. This produced 
a reply from Morellet, the Thérie du paradoxe, I 775. Turning upon Morellet, Linguet wrote a Thérie $d u$ Libelle ou l'art de calomnier avec fruit, I775, in which he bursts into a tirade against the Physiocrats, quoted in the Dictionnaire de l'Économie Politique, I 852. $\mathrm{l}$ He had already assailed them in his Réponse aux docteurs modernes . . . avec la réfutation du système des philosophes économistes, Londres, I $77 \mathrm{I}$, and returned to the charge in company with Mallet du Pan, in his Annales Politiques, r 778, vol. iii. No. xx. p. 275. His diatribes amount to little more than sneers at the occult character of their school and doctrines. $^{2}$ He considered bread a slow poison, and was guillotined in I 794 for having calumniated le pain, la nourriture du peuple. His attack on the Tableau Oeconomique has been recently studied in a monograph by Ad. Philipp, Zurich, 1896.

Of other continental opponents of the Physiocrats it must suffice to mention Johann Jakob von Moser, whose Anti-Mirabeau appeared in I77I ; ${ }^{3}$ Pfeiffer, who wrote Der Anti-Physiokrat, I 780 ; Dohm, the correspondent of Mauvillon, ${ }^{4}$ and author of Kurze Darstellung der physiokratische Systems, Cassel, I 778 ; and Von Sonnenfels, Grundsatze der Polizei, Handlung und Finanz, Vienna, I 765.

1 s.v. Physiocrates, vol. ii. p. $36 \mathrm{I}$.

2 See the quotations in Note B, Appendix.

3 A reply to F. N. Vierordt's Von den Ursprung und Fortgang einer neuen Wissenschaft, Carlsruhe, I770, 8vo, a German translation of Du Pont's Origine et progris d'une science nouvelle.

4 See p. Ioo. 


\section{VI}

WE have so far considered the Physiocrats descriptively,- - their rise and history, the members, the doctrines, the practical activities, and the opponents of the school. We come now to ask ourselves the question, What is the conclusion of the whole matter? They were the first scientific school of Political Economy, but which of the principles they enunciated have survived the storm and stress of criticism, and been incorporated in the progress of science into the wisdom of to-day? If they took the first step, how far did that step go? In other words, what is the produit net of their teaching, and their place in the history of economic theory?

It would, indeed, be distressing if a comparison between the most recent economic writings-the volume e.g. of Professor Marshall's Principles of Economics-and the speculations of the Physiocrats presented no striking variation." Viewed in the - light of a century and a half of scientific progress the Physiocrats seem even to have had but an imperfect appreciation of the central terms and 
radical concepts of the science itself. Their fundamental errors were the identification of Wealth with material objects, and of Value with Cost of Production; their opinion that this Cost of Production was represented by the sum of the material embodied in a commodity, and of the cost of subsistence of those who were occupied in fashioning the raw material; and their conviction that the shifting and incidence of taxation were unimpeded by any effective friction. Given these propositions, most of their conclusions follow by inexorable logic. But it is now a commonplace of economics that the catalogue of Wealth embracing commodities, personal qualities, and services which directly or indirectly satisfy human wants, far transcends the narrow bounds of material goods; that Value depends, not merely on the cost of supply, but also on the intensity of demand, varying with the utility or power which a certain supply of wealth possesses to satisfy the wants of man; that the cost of production, so far as labour is concerned, is not identical with the mere subsistence of the labourers of all kinds who cooperate in production; and that the geometrical elegance of the argument that all taxes fall ultimately on the land is founded upon an unreal hypothesis. It would be absurd to maintain that a sculptor who exercises a divine gift of art upon a block of marble adds to it only the equivalent of his subsistence during the time he is at work; or, in 
other words, that the value of the statue is equal merely to the value of the stone and of his maintenance during the period for which he is engaged. But the progress which we owe to Adam Smith, to Ricardo, to Mill, to Jevons, and many others, must not blind us to the services of the early French writers. The establishment of a clear and cogent Theory of Value,- - the kernel of economic science,has come, indeed, only in the present generation. The originality of the Physiocrats will, perhaps, be most clearly seen by considering what Adam Smith says of them in the Wealth of Nations.

His Fourth Book, it will be remembered, is entitled "Of Systems of Political Economy." "The different progress of opulence," he remarks, "in different ages and nations has given occasion to two different systems of political economy, ${ }^{1}$ with regard to enriching the people." He calls one "The Commercial or Mercantile System," which he says "is the modern system, and is best understood in our own country and in our own times." This is the system of Stateregulation, followed by Colbert. The other is the system of the Physiocrats, which Adam Smith examines briefly because he thought it Utopian, ${ }^{2}$ as

1 Adam Smith has himself been described as " the great founder of the industrial system, as distinguished from the mercantile and agricultural systems." Twiss, View of the Progress of Political Economy in Europe since the Sixteenth Century, 1847, p. 160.

2 "If a nation could not prosper without the enjoyment of perfect liberty and perfect justice, there is not in the world a nation which could ever have prospered." 
he considered Free Trade to be also. But he discusses it with care because of its theoretical importance. Its "ingenuity" is frequently praised, and the author is in entire sympathy with its spirit of "allowing," as he says, "every marv to pursue his own interest his own way, upon the liberal plan of equality, liberty, and justice." After a succinct description of this "liberal and generous system," he observes that its "capital error ... seems to lie in its representing the class of artificers, manufacturers, and merchants as altogether barren and unproductive," and upon this capital error he offers five considerations. First, he says, granting that this sterile class reproduces annually, as the Physiocrats assert, "the value of its own annual consumption, and continues at least the existence of the stock or capital which maintains and employs it . . . the denomination of barren or unproductive should seem to be very improperly applied to it. We should not call a marriage barren or unproductive, though it produced only a son and a daughter, to replace the father and mother, and though it did not increase the number of the human species, but only continued it as it was before. . . . As a marriage which affords three children is certainly more productive than one which affords only two, so the labour of farmers and country labourers is certainly more productive than that of merchants, artificers, and manufacturers. The superior produce of the one class, however, does not render the other 
barren or unproductive." This criticism indicates an important influence of the Physiocrats over Adam Smith, for no competent economist would defend the thesis to-day that agriculture is "more productive" of wealth than manufacture.

Secondly, he says, it is "altogether improper to consider artificers, manufacturers, and merchants in the same light as menial servants." For the work of the first, unlike that of the second, fixes and realises itself in some vendible commodity which can replace the value of wages and maintenance. The work of menial servants consists "in services which perish generally in the very instant of their performance," and these truly belong to the barren or unproductive class. Here again Adam Smith is very near to the doctrines of the Physiocrats, for it is, now seen that all labour productive of utility is free from the reproach of being barren. It is, indeed, remarkable that in his unpublished article Honnmes, Quesnay himself admits domestic servants to be indirectly productive, so far as their services liberate the energies of the agricultural classes; and it is not a little curious that the great apostle of the advantages of Division of Labour should uphold the position that the specialisation of domestic service is an economic loss.

Thirdly, the consumption of artificers, etc., is not lost, for even if they produce a value equal only to what they consume, yet their product remains, and 
is so much more added to the stock of the country than if the consumption had been by a menial or a soldier. He hints, moreover, that the manufacturing class may save something out of the fund allotted to them for subsistence, and these savings increase the wealth of society. This had already been suggested by Turgot in his Réflexions.

Fourthly, "Farmers and country labourers can no more augment, without parsimony, the real revenue, the annual produce of the land and labour of their society, than artificers, manufacturers, and merchants." Indeed as division of labour, which increases production, is susceptible of further extension in manufacture than in agriculture, and as manufacturers, etc., "are, as this system seems to suppose, naturally more inclined to parsimony and saving than proprietors and cultivators, they are, so far, more likely to augment the quantity of useful labour employed within their society, and consequently to increase its real revenue."

Fifthly and lastly, even though the wealth of a nation consisted altogether in the quantity of subsistence which its industry could procure to it, yet " the revenue of a trading and manufacturing country must, other things being equal, always be much greater than that of one without trade or manufactures. . . A small quantity of manufactured produce purchases a great quantity of rude produce." And as a town draws to itself such a quantity of 
raw produce as supplies not only the materials of work but also the means of subsistence, so a trading country like Holland "draws a great part of its subsistence from other countries-live cattle from Holstein and Jutland, and corn from almost all the different countries of Europe."

After these criticisms comes a generous tribute to the system which, "with all its imperfections, is perhaps the nearest approximation to the truth that has yet been published upon the subject of political economy.... Though in representing the labour which is employed upon land as the only productive labour, the notions which it inculcates are perhaps too narrow and confined; yet in representing the wealth of nations as consisting, not in the unconsumable riches of money, but in the consumable goods annually reproduced by the labour of the society, and in representing perfect liberty as the only effectual expedient for rendering this annual reproduction the greatest possible, its doctrine seems to be in every respect as just as it is generous and liberal. Its followers are very numerous, and as men are fond of paradoxes, and of appearing to understand what surpasses the comprehension of ordinary people, the paradox which it maintains, concerning the unproductive nature of manufacturing labour, has not perhaps contributed a little to increase the number of its admirers. . . . Their works have certainly been of some service to their country, 
not only by bringing into general discussion many subjects which had never been well examined before, but by influencing in some measure the public administration in favour of agriculture. It has been in consequence of their representations, accordingly, that the agriculture of France has been delivered from several of the oppressions which it laboured under. . . The ancient provincial restraints upon the transportation of corn from one province of the kingdom to another have been entirely taken away, and the liberty of exporting it to all foreign countries has been established as the common law of the kingdom in all ordinary cases." It must be remembered that all this was written before the fall of Turgot in 1776.

In his Fifth Book, dealing with Taxation, Adam Smith refers ${ }^{1}$ to the impot unique, "recommended by that sect of men of letters in France who call themselves the economists, as the most equitable of all taxes. All taxes, they pretend, fall ultimately upon the rent of land, and ought therefore to be imposed equally upon the fund which must finally pay them. That all taxes ought to fall as equally as possible upon the fund which must finally pay them is certainly true. But without entering into the disagreeable discussion of the metaphysical arguments by which they support their very ingenious theory," he proceeds to show "what are the taxes which fall 1 Wealth of Nations, bk. v. ch. ii. 
finally upon the rent of the land and what are those which fall finally upon some other fund." The chief objection which he saw to the impôt unique, a percentage of the produit net varying of course in its total yield with the state of the harvests, was "the discouragement which it might ... give to the improvement of land. . . . The landlord would certainly bc less disposed to improve when the sovereign, who contributed nothing to the expense, was to share in the profit of the improvement." The Physiocrats urged that their plan drew the attention of the sovereign towards the improvement of the land, from a regard to the increase of his own revenue. But Adam Smith thought no such incitement to the attention of the sovereign "can ever counterbalance the smallest discouragement to that of the landlord. The attention of the sovereign can be at best but a very general and vague consideration of what is likely to contribute to the better cultivation of the greater part of his dominions. The attention of the landlord is a particular and minute consideration of what is likely to be the most advantageous application of every inch of ground upon his estate." "The principal attention of the sovereign ought," he says, "to be to encourage, by every means in his power, the attention both of the landlord and of the farmer, by allowing both to pursue their own interest in their own way, and according to their own judgment, by giving to both the most perfect security that they 
shall enjoy the full recompense of their own industry, and by procuring to both the most extensive market for every part of their produce," by promoting internal communications, "as well as the most unbounded freedom of exportation to the dominions of all other princes."

Professor Oncken has stated that even to-day the physiocratic system awaits its scientific refutation. ${ }^{1}$ This is the language of an enthusiast, justified only in part even if we confine our attention to the criticisms of Adam Smith. The Earl of Lauderdale (1752-1839), a conscientious and sympathetic student of the French economists, quotes and translates numerous passages from their writings, the Tableau Oeconomique, the Physiocratie, the Philosophie Rurale, the Ephémérides, and from Turgot and Morellet; but he attacks their view that "even the labour of the artificer and the manufacturer is totally

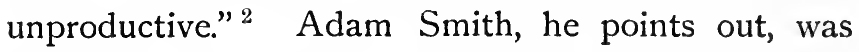
far from consistent. In Book II. chap. i. of the Wealth of Nations he had stated that "lands, mines, and fisheries, require all both a fixed and circulating capital to cultivate them; and their produce replaces with a profit not only those capitals but all the others in the society," while the Physiocrats had not "with all their ingenuity done so much to support

1 Euvres de Quesnay, 1888, p. xix.

2 An Inquiry into the Nature and Origin of Public Wealth, and into the means and causes of its increase, Edinburgh, 1804, pp. 133, $293,134,275$. 
this doctrine [the sterility of non-extractive labour] as the author of the Wealth of Nations, by the manner he has attempted to refute it." In Lauderdale's view "wealth can alone be increased by the means by which it is produced"; and to this end land, labour, and capital co-operate, and each of them, in greater or less measure, becomes productive. George Purves, who had published under his real name in I 8 I 5 The Happiness of States, by Simon Gray, expresses opinions similar to Lauderdale's in All Classes Productive of National Wealth, or the Theories of $M$. Quesnai, Dr. Adam Smith, and Mr. Gray, concerning. the various classes of men as to the production of Wealth to the Community, London, I 8I7, but he emphasises the importance of intelligence and enterprise as a factor in production. Simon Gray's theory - the "productive" theory — was, he says, the true one, not the "unproductive" theories of Quesnay and Smith, who merely drew the line higher up than Quesnay without perceiving that the landed interest derives its income from other classes quite as much as they depend upon the landed interest. Air, heat, and water are as necessary and useful to man as the soil. . Heat is even as extensively so. But how false and absurd would it be to say because heat was absolutely necessary to man, directly or indirectly, in all his operations in producing wealth, that heat is the sole source of wealth! What the economist affirms of the soil is indeed true of human reason (pp. I 5-I 8). 
In a shallow criticism of Adam Smith, M'Culloch has stated that, unaware of the later Ricardian theory of rent, "his refutation of the system of the Economists is far from satisfactory," because when none but the most fertile soils are cultivated there is no rent at all. The produit net is therefore by no means a natural and necessary phenomenon in agriculture. ${ }^{1}$ The impôt unique, which had possibly been suggested to Quesnay by a statement of Locke that all taxes fall ultimately upon the land, is sufficiently condemned by various arguments mentioned in the course of these lectures. It may be added that there are further and fatal objections of a practical character. The metayer or the peasant proprietor who produces for his own consumption, and has but a small surplus with which to satisfy his few and simple requirementsin other words, the agriculturist who is practically self-supporting-would find himself afflicted with an intolerable and disproportionate burden not to be shifted off, as the Physiocrats supposed, by raising the price of his produce, for this virtually never finds its way into the market at all, but is consumed on the farm where it is produced. Moreover, in modern States, no financier would venture to leave the

1 Wealth of Nations, edition 1839, p. 305 note. M'Culloch should have added, to make his statement complete, the conditions that the soils cultivated are all equally advantageous, and that there is no monopoly of supply. This would have deprived his statement of all practical significance. 
equilibrium of public income and expenditure at the mercy of the seasons, with a single source of revenue fluctuating according to the vicissitudes of the weather, neither to be predicted nor controlled. Finally, the enormous budgets of to-day, so far from being balanced by a quarter or a third of the produit 3 . net, ${ }^{1}$ would, in many States, present a yawning deficit even after appropriating the whole agricultural rent of the country. Proudhon invoked the name of the Physiocrats in support of his proposal to tax rents $\mathrm{I} O 0$ per cent, and to impose additional taxes also, to each of which suggestions the school of Quesnay would have offered strenuous resistance, the first violating the sacred right of property by arbitrary confiscation, the second a departure from the impott unique. Mr. Henry George has, in his Progress and Poverty, made a similar mistaken appeal to the Physiocrats, though he has the candour to state that he has not read their original writings. ${ }^{2}$ But it is in the main on principles like theirs (see p. 72, supra) that Mill proposed the taxation of the unearned increment of land, and that philosophers like Professor Sidgwick

1 The impot unique was never to exceed $\frac{8}{20}$, or at most $\frac{1}{3}$, of the produit net, -in other words, was to be a tax of $6 \mathrm{~s}$. to $6 \mathrm{~s}$. $8 \mathrm{~d}$. in the $£$ on agricultural rent. The nature of the proposal is misunderstood not only by Voltaire, Proudhon, and Henry George, but also in another manner by Mr. Lecky, who describes it as " a single tax to be paid by every man in strict proportion to his income." Hist. of England in I 8 th century, and ed. 1887, vol. v. p. 370.

2 He dedicates his Protection or Free Trade? (New York, I 891) " to the memory of those illustrious Frenchmen of a century ago, Quesnay, Turgot, Mirabeau, Condorcet, Dupont and their fellows, who in the night of despotism foresaw the glories of the coming day." 
regard unearned increment of every kind as a preeminently suitable object of taxation provided it can be attained. It cannot, of course, be any longer successfully maintained that all taxes ultimately fall on the land, or that either in theory or practice the land is a suitable object to bear, in the first instance, the whole burden of taxes.

Malthus (1766-1834) shows in his writings an affinity with the Physiocrats, which must undoubtedly be traced to their direct influence. Quesnay and Mirabeau had laid down propositions which contain the germ of his theory of population, though his views on this subject were probably arrived at independently. But he is in close correspondence with the ideas of the school in the importance which he attaches to the disposable surplus produce of the country as its real fund of wealth ; and he seems, like them, to emphasise the essential importance of a maximum production of the means of subsistence. ${ }^{1}$ On the other hand, he differs entirely from the rigorously deductive and absolute frame of mind which is one of their main characteristics, and refuses to give an unqualified adherence to their arguments for Free Trade. Dugald Stewart, the friend and biographer of Adam Smith, held the balance carefully between Smith and the Physiocrats, and concluded

1 Cf. e.g. "The great position of the Economists will always remain true, that the surplus produce of the cultivators is the great fund which ultimately pays all those who are not employed upon the land" (Essay on Population, edition $\left.\mathrm{ISO}_{3}, \mathrm{p} .435\right)$. 
that the French economists were more nearly right than their great critic. Sometimes, he admits, Adam Smith, though substantially in agreement, gains a verbal victory over them. At other times, as in his views upon productive and unproductive labour, he is less consistent than they. Generally speaking, the Physiocrats are more precise and definite in their language, and more scientific in their principles, which are founded on a more accurate metaphysical analysis. Yet the doctrines of the Wealth of Nations are, "with a very few exceptions, of greater practical utility" to statesmen and men of business. ${ }^{1}$ Among minor economic writers we find Paley making the following statement in his Moral Philosophy: "Let it be remembered, then, that agriculture is the immediate source of human provision, that trade conduces to the production of provision only as it promotes agriculture; that the whole system of commerce, vast and various as it is, hath no other public importance than its subserviency to this end" (p.476). But the chief follower of the Physiocrats in England was William Spence, the antagonist of James Mill. Spence's Britain Independent of Commerce, I 808, and his Agriculture the Source of the Wealth of Britain, I 808, were published, together with two others, on the Corn Bill and the East India Trade under the title of Tracts on Political

1 Lectures on Political Economy, vol. i. p. 306. The whole discussion is well worth reading, pp. 253-308. These lectures, delivered at the beginning of the century, were edited by Sir IV. Hamilton, and published at Edinburgh, 1877.2 vols. 8 vo. 
Economy, 1822. Spence endeavoured to show that even if Napoleon succeeded in ruining the foreign trade of the country we might still maintain our prosperity unimpaired. He examines the doctrines of the Physiocrats with some skill. Their "grand axiom" that agriculture is the great source of national wealth he declares to be "undoubtedly founded in truth." But he urges against them that in Britain the influence of manufactures has been the cause of thriving agriculture. "Agriculture and manufactures are the two chief wheels in the machine which creates national wealth"; but in Europe "it is the latter which communicates motion to the former" (p. 27). Owing to the monopoly of the soil, the mainspring of the machine upon which the motion of these wheels depends is the class of land proprietors. $\mathrm{He}$ urges that all taxes are finally paid out of the neft produce of the soil. Adam Smith has, he says, virtually admitted this by laying down that all revenue must be derived from rent, profits, or wages, for he allows that taxes on profits are always shifted on to the consumer, and that "taxes on wages cannot finally fall upon wages, since the wages of the labourer increase in proportion as the price of the articles he consumes is augmented by taxation. On what, then, can taxes fall, but upon the rent of land ?" (p. 37). Yet, says Spence, though all taxes are ultimately paid out of rent, it by no means follows "that no tax except a land-tax should ever be levied." 
To Britain Independent of Commerce James Mill replied in his well-known Commerce Defended, I 808, and Torrens in The Economists Refuted, the same year, the latter combating the Physiocrats with the arms of Lauderdale. If Spence admitted the axiom of the Economists he must, Mill says, admit the whole of their system which is built upon it "with logical and unquestionable exactness." But Spence resists this conclusion. Adam Smith, he says, did not embrace their system. Yet he adopted their axiom, for in Book II. chap. i. par. 28 of the Wealth of Nations he has the passage already quoted (pp. I 32, I 33, above). The truth is, nothing would be easier than to select sentences in which Adam Smith exhibits the influence of the Physiocrats, notably in his arguments that capital is more productively employed in agriculture than in manufacture, still more than in commerce, and that internal commerce is more productive of national wealth than foreign trade. $\mathrm{He}$ was in Paris in I 766 when Turgot was composing his $R e^{\prime}-$ flexions. He was acquainted with the Physiocrats and their writings, and proposed to dedicate the Wealth of Nations to Quesnay, for whom and for whose system he expressed the highest respect. ${ }^{1}$, But in the long retreat at Kirkcaldy he carefully

1 The statement often made that he kept up an active correspondence with Turgot has now been disproved. See Economic Journal, March I896, p. 166. 
sifted their doctrines, and definitely rejected some of them. An "agricultural system" seems, as it were, to spring from the soil in a mainly agricultural country at an early stage of economic reflection. It is to be found in Spain even earlier than in France; Adam Smith has illustrated it by comparisons with Egypt and India; and Mr. Garret Droppers tells us ${ }^{1}$ that it had an independent birth in Japan; while the analogy of China so forcibly impressed the Physiocrats that they were seized with an enthusiasm even for the Celestial government, derided by de Tocqueville as imbécile et marbare. ${ }^{2}$ In countries like Holland or England the theory was too sharply in contrast with the facts of commercial activity to find a favourable soil. Most of the teaching of the Physiocrats has come down to us through Adam Smith, ${ }^{3}$ and even some portions of it which he accepted have since been discarded. But much remains. The younger Mill's chapter on Unproductive Labour in which he classes as "unproductive" certain kinds of labour and consumption admittedly useful to society as a whole, and his chapter on Circulating and Fixed Capital in the same book (Book I. Principles of Pol. Econ.) show us how long-lived much of the analysis of the Physiocrats

1 Proceedings of the Asiatic Society of Japan, IS95.

2 In modern times M. Le Play has held up to the admiration of " unstable" France the morality of China as a basis of material solidity and social permanence.

3 See Note C, Appendix. 
has been. Their rudimentary analysis of capital into avances foncières, primitives, and annuelles according as it was sunk in the soil, laid out for movable stock and plant at the outset, or expended for annual maintenance and renewal, marks the discriminating and systematic frame of mind with which they commenced to reduce economic phenomena to organised science. And their other scientific contributions of temper and method almost evade special recognition so closely are they identified with, and incorporated in, current doctrine. It is their spirit working through Say and Garnier which animated Bastiat, and still inspires the optimism of the French classical school, not always to its advantage. Biology has shown us "the struggle for existence," "the survival of the fittest," in animated nature, which rudely shakes the foundation of their assumption that to let things alone will produce social peace and harmony. Their followers, advocates of liberty, sometimes seem to have surrendered the greatest of all freedom, the unfettered play of the intellect. Content to reason in a dogmatic, unhistorical spirit from a few general principles, they pay insufficient attention to modifying facts in social phenomena, become unreal, and fall into scientific stagnation. The founders of the school were, in one sense, deeply influenced by their environment. Finding, like Malthus, the bow bent too much in one direction, they bent it too much in the other in the effort 
to make it straight. The miserable state of the nation seemed to demand a volte face. Taxes were many and indirect. Let them be single and direct. Liberty of enterprise was shackled. Let it be free. Stateregulation was excessive. Laissez faire! Their economic plea for liberty is buttressed by an appeal to Nature, greater than kings or ministers, and by an assertion of the natural, inherent rights of man to be unimpeded in his freedom except so far as he infringes upon that of others. Unlike Locke and Montesquieu and Rousseau they refuse to admit that man's natural rights are modified by any form of social contract. To these rights even the State must bow ; and the Declaration of Rights which precedes the Constitution of I 79 I borrows from them its second article - that liberty, property, and security are inalienable and imprescriptible rights. Fanciful as it may seem that they proposed to limit the royal power within the vague circle of what was "advantageous to the nation" or consonant with reason (l'ordre naturel), under pain of forfeiting all claim to obedience, such a limitation is not far removed in principle from the constitutional check of the Supreme Court on legislation in the United States, while the economic history of England shows us objections to royal charters to companies engaged in foreign trade, on the ground that monopolies were in derogation of "a right natural and human." To illustrate the social utility of the sanctity of contract 
Montesquieu had devised the fable of the Troglodytes, a simple folk who lived in virtue and happiness, until there spread among them a disregard for the fulfilment of engagements, rapidly followed by mutual distrust and social anarchy. In like manner the ethical and the economic system of the Physiocrats appeared to be but different sides of the same object. They propound, before Bentham, the principle of enlightened self-interest. In diametrical opposition to Mandeville's Private Vices Public Benefits they consider that every vice is a public injury. To maximise the produit net was, in their view, to promote the best interests of society, and vice versâ. An action was in fact good or bad according as it increased or decreased, directly or indirectly, the welfare of society; and they contended that every anti-social action could be shown to diminish the net wealth of society, every laudable action to increase it. From this point of view they would have rejected the ridiculous paradox of Bastiat that the State does harm even when it does good; but they seem, like Adam Smith, to go sometimes dangerously near the doctrine that self-interest is identical with the interest of society as a whole. Cossa's view that they dealt a last and decisive blow at the theory of the economic omnipotence of the State is perhaps somewhat sanguine if we look at the world of action instead of the world of ideas. But at any rate they went to the roots of economic and financial condi- 
tions. They showed that taxes do not always rest where they seem to fall, that in the long-run the State suffers by an unfair and unequal distribution of its burdens, and, above all, that the economic welfare of a nation may be stifled by excessive restrictions. Their impôt unique might have proved, as Voltaire said, an impôt inique; but in probity and honesty of purpose they fought earnestly against injustice and oppression. At the Revolution the nation desired the abolition of indirect taxes, but the war budgets defeated the project. The modern tendency in England has shown a remarkable movement in this direction, over 40 per cent of the national income now coming from direct taxation, as compared with 25 per cent a quarter of a century ago. The Treaty of Commerce with England in I 786 must be regarded as the last important success of the Physiocrats in the field of politics. The corvées, the farming of taxes, and the jurandes were abolished at the Revolution, and a tax was laid upon all land without privilege or exemption.

The Physiocrats form at once the first and the most compact school to be encountered in the history of economics. The first to share and provoke a wide- . spread enthusiasm for the study of economic causes and effects, they stood boldly together-- daring, original, sometimes paradoxical, but rendering great service to future ages by their luminous and penetrating theories, which spread like a wave over the 
whole Continent. The rulers of the earth did not disdain to learn from them. And though their own country, for which they wrote and worked, still turns a deaf ear to one part of their pleading, it must be remembered that Adam Smith and Pitt, Huskisson, Peel, and Gladstone have but repeated their arguments in endowing us, for better or for worse, with our settled policy of Free Trade. 


$$
-
$$




\section{APPENDIX}

Note A

Louis XV., who himself chose Quesnay's arms and gave him three pansies (pensées) with the motto propter cogitationem mentis, was accustomed to refer familiarly to him as mon penseur. But, to say nothing of the dates, these facts do not justify us in assuming that the roi fainéant took any interest in Quesnay's economic studies. The phrase mon penseur appears to the present writer to be a mere royal pun upon his pensive physician. The French verb panser, to give medical (and especially surgical) assistance, lent itself to a play upon penser. On one occasion the king turned to a young seigneur who had returned from England with an affectation of British phlegm, and playfully asked, "Eh bien! qu'est-ce que vous avez appris en Angleterre?" "Sire," was the pompous reply, " $j$ 'y ai appris à penser." "Des chevaux sans doute," added the king-a parallel jest. This form of wit was very common at the Court of Louis XV. A blood-letting barber was styled le seigneur (saigneur) barbier.

Note B

The Réponse aux Docteurs modernes, ou apologie pour l'Auteur de la Théorie des Loix, et des Lettres sur cette 
Théorie. Avec la réfutation du systême des Philosophes économistes. Par Simon-Nicolas-Henri Linguet. MDCCLXXI, I $2 \mathrm{mo}$, vol. i. 300 pp., vol. ii. 259 pp., is so rare that some further reference to it may be found useful. A copy of the book will be found in the Bibliothèqu Nationale at Paris, press mark R. 2 1096-7.

Linguet takes for his motto an extract from the Éphémérides of his adversaries, I 769 , vol. iii., Avertissement, p. 16: "Il faut faire la guerre aux foux même quand ils deviennent furieux, et la leur faire bonne et vive, jusqu'à ce qu'on les ait mis dans l'impuissance de nuire."

He says: "Les économistes, c'est-à-dire des abbés, des gentilhommes, des horlogers [a hit at Du Pont, the son of a watchmaker], des juges de provinces etc. sont venus apprendre tout d'un coup aux meûniers qu'ils ne savoient pas meudre [a reference to the moulins économiques], au peuple qu'il avoit trop d'appétit, aux bourgeois qu'ils laissoient trop de gruau dans leur son; et l'on a battu des mains.

"De leur boulangerie, ils ont passé à la jurisprudence et aux loix. D'une main toute blanche encore de leur pâte et de leur mouture, ils se sont avisés de vouloir repâitrir notre législature; de derrière des meules bien ou mal repiquées, on a été fort surpris de voir sortir des Solons enfarinés, qui ont prétendu réformer toute la machine politique ; et l'on a encore battu des mains" (p. 9). As for himself, who has studied jurisprudence, he will expose this imperious sect which has spoken so much of destroying prejudices, and has created so many. The encyclopædic yeast of thirty years ago stirred the nation with a certain Anglican effervescence. When the great dictionary appeared began the epoch of fanaticism. And when the Government suppressed the Encyclopédie, then the buzzing insect since called 
Economics took its place, but, unlike the caterpillar turned butterfly, it was a butterfly turned caterpillar, losing its metaphysic wings and grovelling on the earth, crawling on the bread it gnaws (p. I3). Better old errors which left us alive, than new ones like these which are murderous (p. I4).

The Physiocrats are a dangerous sect, powerful, popular, and much read, unlike himself who has not had the precaution to form a sect or dress up his writings with an ecstatic and philosophic varnish. In vain does $\mathrm{Du}$ Pont protest they are not a sect. Linguet says: Not a sect? Evidence shows it: your mysterious words, physiocratie, produit net; your mystic jargon, ordre, science, le maître; your titles of honour showered on your patriarchs; your wreaths scattered through the provinces on obscure if excellent persons-the "celebrated" Le Trosne, the "admirable" Saint-Péravy, the " excellent" Treilhard, etc. (p. I 20). Not a sect? You have a rallying cry, banners, a march, a trumpeter [Du Pont], a uniform for your books, and a sign like freemasons (p. I2I). Not a sect? One cannot touch one of you but all rush to his aid. You all laud and glorify each other, and attack and intimidate your opponents in unmeasured terms. You affect an inspired tone and seriously discuss on what particular day the symbol of your faith, the masterpiece, the Tableau Oeconomique was born,- - a symbol so mysterious that huge volumes cannot explain it. It is like the Koran of Mohamet. You burn to lay down your lives for your principles, and talk of your apostleship (p. I 25 ). You attack Galiani and me because we have no reverence for that ridiculous hieroglyphic which is your holy Gospel. Confucius drew up a table, the $Y$-King, of sixty-four terms, also connected by lines, to show the evolution of the elements, and your Tableau Oeconomique is justly enough compared to it, but it comes three hundred years too late. 
Both alike are equally unintelligible. The Tableau is an insult to common sense, to reason, and philosophy, with its columns of figures of reproduction nette terminating always in a zero, striking symbol of the fruit of the researches of any one simple enough to try in vain to understand it.

The Physiocrats are the anabaptists of philosophy, who propose to kill men to make them happy. Starvation is their best protection. Everything comes from the land. Therefore, the political ideal is the cultivation of corn. But to farm with the greatest advantage requires large capitals. Therefore favour opulence. Opulence will result from high prices, which will come from rarity. Therefore export corn, and thus starve the people.

Linguet prints side by side the Tableau Oeconomique and the $Y$-King. It is hardly necessary to point out that he fails to understand the economic doctrines he satirises.

Dr. Bauer has quoted some of Linguet's invectives from the Annales Politiques, 1778 , in his article on Quesnay's Tableau Oeconomique, Economic Journal, vol. v. p. 19, March I 895 .

\section{Note C}

Since these lectures were delivered, "Adam Smith's Lectures on Justice, Police, Revenue, and Arms, delivered in the University of Glasgow by Adam Smith, reported by a student in ${ }_{1} 76_{3}$, and edited with an introduction and notes by Edwin Cannan, Oxford, I 896 ," have been published by the Clarendon Press. The editor thinks these lectures "dispose finally of the Turgot myth" (that Adam Smith was indebted to Turgot's Réflexions), and that they enable us "to distinguish positively between what the original genius of its author created out of British materials on the one hand, and French materials on the other." Mr. 
Cannan says: "It is plain that Smith acquired the idea of the necessity of a scheme of distribution from the Physiocrats, and that he tacked his own scheme (very different from theirs) on to his already existing theory of prices" (p. xxxi.).

The present writer has briefly discussed the bearing of this volume upon the relations between Adam Smith and the Physiocrats in the Economic Journal, December I 896. 


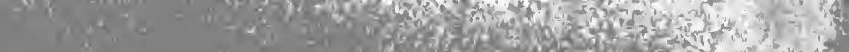

What

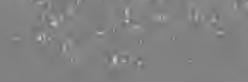

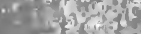

$-5 x^{3}$

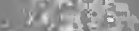

ativin

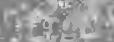

Fin

108,4 is

$+8=2 \sqrt{2}$

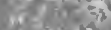

terso

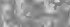

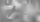

$x \rightarrow$ onet

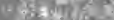

- inger

sising:

$+452=$

A.

$3 \pi n$

Piv ad 200 ont is

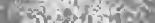

$x y^{4}$

sice
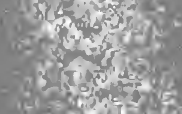

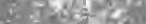
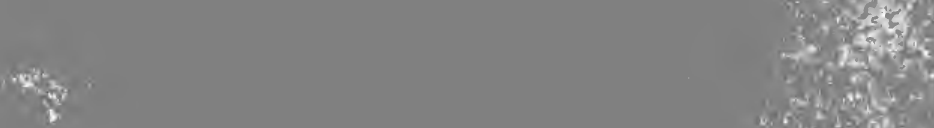

$a x$

onge?

$x^{2}+2=$

$a^{2}+t^{2}$

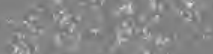

$x_{2}=-y_{2}$

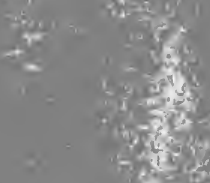

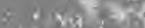

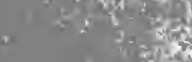

$f_{0}, 802$

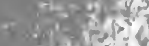

exisal

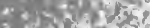

coopon

1. 050 


\section{AUTHORITIES}

\section{LECTURE I}

H. Taine, L'Ancien Régime, bk. v., Le Peuple, r875; R. Stourm, Les finances de lancien régime; C. Knies, Introduction to Carl Friedrichs von Baden brieflicher Verkehr mit Mirabeau und Du Pont (Heidelberg, 1892, 2 vols.); articles on Cantillon by W. S. Jevons in Contemporary Review, Jan. I88I, and by H. Higgs in Economic Journal, June 1891, and in Quarterly Joumal of Economics (Harvard, U.S.A.), July 1892 ; L. de Loménie, Les Mirabeau (Paris, I889-1891, 5 vols.); L. de Lavergne, Les économistes français du XVIIIe siècle (Paris, I 870 ).

\section{LECTURE II}

Tableau Oeconomique (printed for the British Economic Association, London, I894); G. Kellner, Zur Geschichte des Physiocratismus (Göttingen, 1847); A. Oncken, EEzvres de Quesnay (Frankfort), I888; do., Die Maxime Laissez-faire et Laissez-passer, ihr Ursprung, ihr Werden (Berne, I886); do., Zur Geschichte der Physiokratie in Schmoller's Jahrbuch for I 893 ; S. Bauer, Zur Entstehung der Physiokratie in Conrad's Jahrbiicher for August I890; do., Quesnay's Tableau Oeconomique in Economic Joumal for March I 895 ; W. Hasbach, Die allgemeinen philosophischen Grundlagen der von François Quesnay und Adam Smith begriindeten politischen Oekonomie (Leipzig, I 890).

\section{LECTURE III}

A. Stern, Das Leben Mirabeaus (Berlin, I 889); A. Oncken, Der ältere.Mirabeau und die ökonomische Gesellschaft in Bern (Berne, 
I S86); G. Schelle, Du Pont de Nemours et l'École physiocratique (Paris, I 888) ; E. Daire, Les Physiocrates (Paris, 1846, 2 vols.); R. Reuss, Ch. de Butré (Strasburg, 1890) ; L. Say, Turgot (Paris, 1887), translated by G. Masson (London, I 888 ).

\section{LECTURE IV}

A. Emminghaus in Conrad's Jahrbuch for 1872 ; J. Rae, Life of Adam Smith (London, I893); A. Oncken, Ludwig XVI. und das physiokratische System, in Zeitschrift für Litteratur und Geschichte der Staatswissenschaften, I893; A. von Miaskowski, Isaak Iselin (Basle, 1875); W. B. Hodgson, Turgot: his Life, Times, and Opinions (London, I870).

\section{LECTURE V}

L. Cossa, Guide to the Siudy of Political Economy (London, I890); J. Kautz, Die geschichtliche Entwickelung der Nationalökonomik (Leipzig, I868); J. Ingram, History of Political Economy (London, I888); W. Roscher, Geschichte der Nationalökonomie in Deutschland (Leipzig, I 874); also the articles Physiocrates and Physiokratische Schule in the French and German Dictionaries of Political Economy, and, generally, under the names of all the authors mentioned in the Lectures, the articles in these Dictionaries and in the English Dictionary of Political Economy now approaching completion.

\section{LECTURE VI}

Gomel, Les causes financières de la revolution française; A. De Tocqueville, L'Ancien Regime (1859); L. Blanc, Histoire de la revolution française, vol. i.; G. Cohn, History of Political Economy (1 894); Hector Denis in Annales de l'institut des sciences sociales (Bruxelles, Jan. I896); S. Feilbogen, Smith and Turgot (Vienna, 1892); J. Bonar, Philosophy and Political Economy (London, I893); W. Hasbach, Les fondements philosophiques de l'économie politique de Quesnay et de Smith in Rśrue d'Economie Politique (September, I893). 


\section{N D E X}

Abeille, 69, 75, 76, 82

Acton, 67

Alary, 14

Albon, Comte d', 22, 50, 8I

Aquinas, 93

Asgill, I6

Bachaumont, r2o

Baden, Carl Friedrich, Margrave of, $64,69,72,82 \cdot 89,99$

Barbeyrac, 27

Barbon, I 7

Bastiat, I4I, I 43

Batbie, I 6

Baudeau, $43,63,64,75.82$, 90, 9r, II9, I 20

Bauer, vii, viii, $\mathrm{r} 7,35,42,80,8 \mathrm{I}, \mathrm{I} 50$

Beaumont, Abbé de, I2

Belle-Isle, Maréchal de, 78

Belly, 82

Bentham, 29, 46, 93, I 43

Berkeley, 53

Bernoulli, 8o

Blanc, Louis, I

Blei, r2o

Boisguillebert, I I-13, 67

Boislisle, A. M. de, I2

Bolingbroke, 14

Bonar, I 54

Boscovitch, 58

Britannia Languens, I7

Broglie, Maréchal de, 78

Buckle, I $_{3}$

Buffon, 48

Butré, 82
CANNAN, I9, I 50, I 51

Cantillon, 16-19, 21, 23, 30, 35-37, $52,67,94,96$

Carlyle, I, I I I

Casaux, Marquis de, II2

Catherine of Russia, 79, 88, 89, I6r

Chamfort, Marquis de, II

Charles III. of Spain, 89

Chastellux, Marquis de, viii

Child, I 5,67

Choiseul, Duc de, 78, 83, ro3

Cicé, Abbẻ de, 9I

Clément, 8

Club de l'Entresol, 14

Cohn, I

Colbert, 5, 8, 35, 67,69, I I6, I I 7, I21, 125

Condillac, 97, 98

Condorcet, 98, I 16,135

Corvée, 8, 28, 91, 92, I44

Cossa, 94, 99, 100, I43

Culpeper, 15,67

Cumberland, 27, 46

Czartoryski, 64

DAIRE, $32,43,53,57,68,72,75$, 84,104

D'Alembert, $\mathbf{1}_{5}, 48$

D'Angeul, 32, 35

D'Argenson, I4, 20, 67

Dauphin, son of Louis XV., 26, 45,89

Deffand, Mme. du, 83

De la Touane, 82 
Denis, I 54

Descartes, I I I

Diderot, I 5, 23, I I 7

Dohm, roo, I1 2

Droit d'aubaine, 92

Droppers, I40

Du Hausset, Mme., 50

Du Pin, I 5

Du Pont de Nemours, $35,53,56$, $60-69,75-77,79-82,86,87,89-$ 9I, 97, I04, II6, II9, I20, I22, I35, I48, 149

Dupré de Saint Maur, 29, 35

Education, 58, 88

Emminghaus, 86

Espinas, 19

FARMERS-GENERAL, 7, 54

Feilbogen, vii, I 54

Fénélon, I I

Ferdinand of Naples, 89

Fleury, Cardinal de, I4

Forbonnais, 8, 43, 57, 79, 102-104, I 2 I

Fortrey, I7

Fouchy, Grand Jean de, 22, 48

Fourier, 46

Fourqueux, I 5,82

Foxwell, 46

Franklin, 82

Fréville, 82

Fürstenau, Ioo

Gabelle, 7

Galiani, 77, 90, 97, I I7-120, 149

Galitzin, 69, 79, 99, I O I, I I 2

Garnier, I4 I

George, Henry, 135

Gerbier, 84

Giffen, 32

Gladstone, 145

Gomel, I 54

Gournay, I 5, 66, 67, 90, 92, 97

Graslin, I 20

Gray, I 33

Grimm, 57, I 20

Grivel, $5^{8}$

Grotius, 46
Guiraudet, I $2_{2}$

Gustavus III., 87

HALE, 54

Hamilton, Sir W., 137

Harrison, 48

Hasbach, vii, 27, 46

Hénault, I4

Herbert, 15, 35

Higgs, I6, 1 8, 149

Hodgson, 48, I 54

Hugo, Victor, 20, 52

Hume, I5

Huskisson, I45

IMPÔT UNIQUE, 29, 44, 56, 86, 90, 99, I03, I I 5, I30, I3 I, I 35, I44

Iselin, 99-IOI

JEVONS, I6, 98, I25

Joseph II. , 89, 90

Jurandes, 92, 144

Jussieu, de, 48

KAutz, 16, 99

Kellner, 153

Knies, vii, 79, 89

Krug, 99, I00

LA BRUYÈRE, I I

La Condamine, 48

La Rochefoucauld, 78

Lauderdale, $\mathbf{1 3 2}_{\mathbf{3}}, \mathbf{x}_{33}, \mathbf{1} 39$

Laulne, Abbé de (i.e. Turgot), 97

Lavergne, viii, 5, 14, 23, 4I, 98

Law, J., 6, I4, I6, 54, 9 I

Lecky, 135

Le Gendre, 67

Leibnitz, 2 I

Lemontey, 6

Leopold II., 89

Le Pessellier, I I I

Le Play, 140

Le Trosne, $22,63,75,76,82,98$, I49

Levallois, 78

Levasseur, 5

Lieutaud, 48

Linguet, $x, 42,43,121,122,147-$ I 50 
Locke, I $_{5}, 46, \mathrm{r}_{34}, \mathrm{I}_{42}$

Loiseau, 82

Loménie, 2, 49, 51, 60, 63, 83, 84, 97, IOI, II7

Longo, 58, 8I, 99, I0I

MABLY, Abbé de, 2, 104-112, I16

M'Culloch, I 34

Machault, I5

Macleod, 98

Malebranche, 27, 46, 70

Malesherbes, 79, 97

Mallet du Pan, 122

Malthus, I36, I 37, I4I

Malynes, I 7

Mandeville, I43

Marie Antoinette, 89

Marivelt, 53

Marot, 20

Marshall, I23

Maurepas, 77

Mauvillon, 96, 99, 100, 122

Mazarin, 5

Melon, I4

Mercantilists, 3, 16

Mercier de la Rivière, $46,66,68$, $74,79,82,88,90$, IOI, I04, 107, IIO, II2, II9

Messance, 55, II 2

Miaskowski, ror

Militia, 6, 8, 28, 9I

Mill, James, r37, I39

Mill, J. S., 125, 135, 140

Mirabeau, Comte de, II, 52, 59, 83,84, I 12

Mirabeau, Marquis de, 3, I I, 19-25, $35,39,42,49-6 x, 62,68,69,75$, $77-82,85.87,96,97,99$, I01, I 1 $1,112,116,121,135,136$

Montaigne, 20

Montesquieu, $\mathbf{r}_{5}, 20,52,69,121$, I42, 143

Montigny, 60

Morellet, $63,75,82,97,98,119$, I21, I 22, 132

Möser, Justus, Ioo

Moser, F. K. von, 99

Moser, J. J. von, IOo, 122

Moulins économiques, $83,84,146$

Mun, 17,32
Naveau, 35

Necker, 8, 97, 99, 12 I

Newton, 69, IoI

Nivernois, Duc de, 79

North, 17

OCTROI, 92

Oncken, vii, viii, 43, 50, 66, 67, 99, I0O, I 32

Pailly, Mme. de, 79

Paley, I 37

Patullo, 77

Peel, I 45

Pfeiffer, 122

Philipp, 122

Pitt, I45

Poissy, caisse de, 84

Pompadour, Mme. de, 22, 26, 42, 5o, 56, 62

Pomponne, Abbé de, 14

Postlethwayt, I9

Pothier, 75, 93

Produit net, 43, 44, 73, 85, 90, 96, I07, I31, I35, I 43,149

Proudhon, 2, I 35

Purves, I33

QUESNAY, 5, 20-25, 26-48, 50-53, $55-57,60-62,65-68,74,76-78$, $82,89,90,93,98$, I00, I01, 103, I $21,1_{27}, 1_{32} 1_{3} 6,1_{39}, 1_{47}, 1_{50}$

RAE, 68

Ricardo, 125

Rivière, II 2

Rohan-Rochefort, 83

Roscher, 99, I00

Rossi, 2

Roubaud, 77, 81, 82, 119

Rousseau, I, 15, 23, 78, 99, I +2

Roussel de la Tour, $6 \mathbf{I}$

Rouxelin, 82

Saillant, Marquise du, 83

St. Maurice de St. Leu, 82

Saint-Mégrin, Duc de, 82

Saint-Péravy, 76, 82, 1 20, 149

Saint-Pierre, Abbé de, viii, I4, 22, 29, 42 
Saint-Simon, Duc de, I 2

Sainte-Beuve, I 4

Ste. Croix, Bigot de, 82

Sallier, 48

Sand, Georges, I 5

Say, J. B., 3I, 65, 66, 98, I4I

Say, Léon, 2

Schelle, vii, $57,61,63,66,76$

Schlettwein, 99-10 I

Schmalz, 99-I0I

Shaftesbury, 46

Sharp, 48

Sidgwick, I35

Silhouette, I03

Silva, 26

Smith, Adam, 8, 17, 29, 36, 39, $46-48,63,66,68,74,79,86,90$, 93, 94, 96, 98, 125-134, г 36 , I $39,140,143,145, I_{50}, I_{5} 1$

Sonnenfels, 122

Spence, I37-I39

Springer, Ioo

Stanislas of Poland, 89

Stern, vii, I 53

Stewart, D., I36

Stourm, 153

Sudre, I I I

Sully, 30, 35, 40, 4I, 42, I I 6

TAILLE, 6, 7, 10, 27, 28, 31, 91

Taine, I, 5, Io

Terray, 62, 91, 93

Thiébault, 88
Tifaut de la Noue, II2

Tocqueville, De, I, 52, 140

Torrens, 139

'Treillard, 82, 149

Trudaine, I 5,63

Tucker, I $5,31,67$

Tuesday meetings of Physiocrats, 78,79 , I о I

Turbilly, Marquis de, 77

Turgot, 3, 4, 1 5, 27, 48, 49, 58, $60,62,64-67,77-84,90-98$, 100, I 16, I I9, I 20, I 28, I 30, I 32, I $35,139,150$

Twiss, 125

USTARITZ, IO2

Usury, 93, 94

VANDERLINT, 16

Vauban, I2, I3, 46

Vauvenargues, 52

Vauvilliers, De, 82

Vierordt, von, 122

Voltaire, I, 12, I5, 26, 40, 69, 82, 89, 97, I I 2-I I 9, I 43

WAGES FUnd, 95

Walmesley, 48

Watson, 48

Weimar, Princes of, 78

YARRANTON, I7

THE END

Printed by R. \& R. Clark, Limited, Edinburgh. 


\section{MACMILLAN \& CO.'S BOOKS ON ECONOMICS.}

THE ECONOMIC JOURNAL: The Journal of the British Economic Association. Edited by F. Y. Edgeworth. Published Quarterly. 8vo. 5s. net. Vols. I.-IV. 2is. net each.

QUARTERLY JOURNAL OF ECONOMICS. Published for Harvard University. Published Quarterly. 2s. 6d. net.

TABLEAU OECONOMIQUE. By Françors Quesnay. First printed in 1758 , and now reproduced in Facsimile for the British Economic Association. Demy 4to. 2s. 6d. net.

ECONOMIC CLASSICS. Edited by Prof. W. J. Ashley. Globe 8vo. 3s. net each.

SELECT CHAPTERS AND PASSAGES FROM THE "WEALTH OF NATIONS" OF ADAM SMITH, 1776 .

THE FIRST SIX CHAPTERS OF THE "PRINCIPLES OF POLITICAL ECONOMY AND TAXATION" OF DAVID RICARDO, I817.

PARALLEL CHAPTERS FROM THE FIRST AND SECOND EDITIONS OF "AN ESSAY ON THE PRINCIPLE OF POPULATION," BY T. R. MALTHUS, $1798-1803$.

ENGLAND'S TREASURE BY FORRAIGN TRADE, BY T. MUN, 1664 .

PEASANT RENTS, BY R. JONES, 183 r.

THE MERCANTILE SYSTEM, BY G. SCHMOLLER.

SOCiAL Evolution. By Benjamin Kidd. New and Cheaper Edition. (Seventeenth Thousand), Revised, with a New Preface. Crown 8vo. 5s. net.

THE EVOLUtion OF INDUSTRY. By H. Dyer, C.E., M.A., D.Sc. 8vo. ros. net.

DICTIONARY OF POLITICAL ECONOMY. Edited by R. H. Inglis Palgrave, F.R.S. Vol. I. (A-E). Vol. II. (F-M). Medium 8vo. 21s. net each.

ASPECTS OF THE SOCIAL PROBLEM. By various Writers. Edited by Bernard Bosanquet. Crown 8vo. 2s. 6d. net.

Rich AND POOR. By Mrs. Bernard Bosanquet. Crown 8vo. 3s. 6d. net.

PUbliC FinanCE. By C. F. Bastable, M.A., Ll.D., Professor of Political Economy in the University of Dublin. Second Edition, Revised and Enlarged. 8vo. 12s. 6d. net.

ADOPTION AND AMENDMENT OF CONSTITUTIONS IN EUROPE AND AMERICA. By Charles Borgeaud. Awarded the Rossi Prize by the Law Faculty of Paris. Translated by Charles D. Hazen. With an Introduction by JoHN MI. VINCENT, Associate of the Johns Hopkins University. Crown 8vo. 8s. 6d. net.

POPULAR FALLACIES REGARDING BIMETALLISM. By Sir Robert Edgcumbe. Crown 8vo. 3s. 6d. net.

MACMILLAN AND CO., LTD., LONDON. 
By PROF. FRANCIS A. WALKER, Ph.D.

POLITICAL ECONOMY. 8vo. I2s. 6d.

A BRIEF TEXT-BOOK OF POLITICAL ECONOMY. Crown 8vo. 6s. 6d.

FIRST LESSONS IN POLITICAL ECONOMY. Crown 8vo. 5 s. THE WAGES QUESTION. A Treatise on Wages and the Wages Class. Extra Crown 8vo. 8s. 6d. net.

MONEY. Extra Crown 8vo. 8s. 6d. net.

MONEY IN ITS RELATIONS TO TRADE AND INDUSTRY. Crown 8vo. 7s. 6d.

LAND AND ITS RENT. Fcap. 8vo. 3s. 6d.

INTERNATIONAL BIMETALLISM. Crown 8vo. 5s. net.

BY PROF. EUGENE V. BÖHM-BAWEKK.

CAPITAL AND INTEREST. A Critical History of Economical Theory. Translated, with a Preface and Analysis, by William SMart, LL.D. 8 vo. 12s. net.

THE POSITIVE THEORY OF CAPITAL. Translated, with a Preface and Analysis, by Dr. William Smart. 8vo. i2s. net.

NATURAL VALUE. By Friedrich von Wieser. Edited, with a Preface and Analysis, by Dr. William Smart. 8vo. ros. net.

AN INTRODUCTION TO THE THEORY OF VALUE, on the lines of Menger, Wieser, and Böhm-Bawerk. By Dr. William Smart. Crown 8vo. 3s. net.

STUDIES IN ECONOMICS. By Dr. William Smart. Extra Crown 8vo. 8s. 6d. net.

PRINCIPLES OF ECONOMICS. By Alfred Marshall, M.A. Two Vols. Vol. I. Third Edition. 8vo. 12S. 6d. net.

ELEMENTS OF THE ECONOMICS OF INDUSTRY. Being the first volume of "Elements of Economics." By Prof. A. MARShall. Crown 8 vo. 3s. 6d.

THE PRINCIPLES OF POLITICAL ECONOMY. By HENRY SiDGwick. Second Edition. 8vo. 16s.

INTRODUCTION TO THE STUDY OF POLITICAL ECONOMY. 'By Luigi Cossa. Revised by the Author and translated by Louis Dyer, M.A. Crown 8vo. 8s. 6d. net.

By the late PROF. W. STANLEY JEVONS, LL.D., F.R.S.

THE STATE IN RELATION TO LABOUR. New Edition. Crown 8vo. 2s. 6d.

POLITICAL ECONOMY. Pott 8vo. Is.

THE THEORY OF POLITICAL ECONOMY. Third Edition. 8vo. 1os. 6d.

INVESTIGATIONS IN CURRENCY AND FINANCE. Illustrated by Twenty Diagrams. Edited with an Introduction by Prof. H. S. FoxwetL. 8vo. 21s.

MACMILLAN AND CO., LTD., LONDON. 
32 


$$
\begin{aligned}
& H B \\
& 93 \\
& H 6 \\
& 1897 \\
& C \cdot 1 \\
& \text { ROBA }
\end{aligned}
$$


